\title{
The North Atlantic Marine Boundary Layer Experiment (NAMBLEX). Overview of the campaign held at Mace Head, Ireland, in summer 2002
}

D. E. Heard ${ }^{1}$, K. A. Read ${ }^{1}$, J. Methven ${ }^{2}$, S. Al-Haider ${ }^{1}$, W. J. Bloss ${ }^{1}$, G. P. Johnson ${ }^{1}$, M. J. Pilling ${ }^{1}$, P. W. Seakins ${ }^{1}$, S. C. Smith ${ }^{1}$, R. Sommariva ${ }^{1,}$, J. C. Stanton ${ }^{1}$, T. J. Still ${ }^{1}$, T. Ingham ${ }^{1}$, B. Brooks ${ }^{3}$, G. De Leeuw ${ }^{13}$, A. V. Jackson ${ }^{3}$, J. B. McQuaid ${ }^{3}$, R. Morgan ${ }^{3}$, M. H. Smith ${ }^{3}$, L. J. Carpenter ${ }^{4}$, N. Carslaw ${ }^{4}$, J. Hamilton ${ }^{4}$, J. R Hopkins ${ }^{4}$, J. D. Lee Le $^{4}$ A. C. Lewis ${ }^{4}$, R. M. Purvis ${ }^{14}$, D. J. Wevill ${ }^{4}$, N. Brough $^{5}$, T. Green ${ }^{5}$, G. Mills ${ }^{5}$, S. A. Penkett ${ }^{5}$, J. M. C. Plane ${ }^{5}$, A. Saiz-Lopez ${ }^{5}$, D. Worton ${ }^{5}$, P. S. Monks ${ }^{6}$, Z. Fleming ${ }^{6, * *}$, A. R. Rickard ${ }^{6,1}$, M. R. Alfarra ${ }^{7}{ }^{* * *}$, J. D. Allan ${ }^{7}$, K. Bower ${ }^{7}$, H. Coe $^{7}$, M. Cubison ${ }^{7}$, M. Flynn ${ }^{7}$, G. McFiggans ${ }^{7}$, M. Gallagher ${ }^{7}$, E. G. Norton ${ }^{7}$, C. D. O'Dowd ${ }^{12}$, J. Shillito ${ }^{7}$, D. Topping ${ }^{7}$, G. Vaughan ${ }^{7}$, P. Williams ${ }^{7}$, M. Bitter ${ }^{8}$, S. M. Ball ${ }^{8}$, R. L. Jones ${ }^{8}$, I. M. Povey ${ }^{8}$, S. O'Doherty ${ }^{9}$, P. G. Simmonds ${ }^{9}$, A. Allen ${ }^{10}$, R. P. Kinnersley ${ }^{10}$, D. C. S. Beddows ${ }^{10}$, M. Dall'Osto ${ }^{10}$, R. M. Harrison ${ }^{10}$, R. J. Donovan ${ }^{11}$, M. R. Heal ${ }^{11}$, S. G. Jennings ${ }^{12}$, C. Noone ${ }^{12}$, and G. Spain ${ }^{12}$

${ }^{1}$ School of Chemistry, University of Leeds, Leeds, LS2 9JT, UK

${ }^{2}$ Department of Meteorology, University of Reading, Whiteknights, P.O. Box 217, Reading, Berkshire, RG6 6AH, UK

${ }^{3}$ School of Earth and Environment, University of Leeds, Leeds, LS2 9JT, UK

${ }^{4}$ Department of Chemistry, University of York, Heslington, York, YO10 5DD, UK

${ }^{5}$ School of Environmental Sciences, University of East Anglia, Norwich, Norfolk, NR4 7TJ, UK

${ }^{6}$ Department of Chemistry, University of Leicester, Leicester, LE1 7RH, UK

${ }^{7}$ School of Earth, Atmospheric and Environmental Sciences (SEAES), University of Manchester, Manchester, M60 1QD, UK

${ }^{8}$ University Chemical Laboratory, Cambridge University, Cambridge, UK

${ }^{9}$ School of Chemistry, University of Bristol, Cantock's Close, Bristol BS8 1TH, UK

${ }^{10}$ School of Geography, Earth and Environmental Sciences, Univ. Birmingham, Dept. of Physics, Birmingham, B15 2TT, UK

${ }^{11}$ School of Chemistry, University of Edinburgh, West Mains Rd, Edinburgh EH9 3JJ, UK

${ }^{12}$ National University of Ireland, Galway, University Road, Galway, Ireland

${ }^{13}$ TNO, P.O. Box 96864, 2509 JG, The Hague, The Netherlands

${ }^{14}$ Facility for Airborne Atmospheric Measurement (FAAM), Cranfield University, Cranfield, MK43 0AL, UK

*now at: Aeronomy Laboratory, National Oceanic and Atmospheric Administration, Boulder, CO, USA

*** now at: Depart. Environmental Science and Technology, Imperial College of Science, Technology and Medicine, Prince Consort Road, South Kensington, London, SW7 2AZ, UK

${ }^{* * * *}$ now at: Paul Scherrer Institute, Villigen, Switzerland

Received: 16 August 2005 - Published in Atmos. Chem. Phys. Discuss.: 24 November 2005

Revised: 1 March 2006 - Accepted: 30 March 2006 - Published: 21 June 2006

\begin{abstract}
The North Atlantic Marine Boundary Layer Experiment (NAMBLEX), involving over 50 scientists from 12 institutions, took place at Mace Head, Ireland $\left(53.32^{\circ} \mathrm{N}\right.$, $9.90^{\circ} \mathrm{W}$ ), between 23 July and 4 September 2002. A wide range of state-of-the-art instrumentation enabled detailed measurements of the boundary layer structure and atmospheric composition in the gas and aerosol phase to be made, providing one of the most comprehensive in situ studies of
\end{abstract}

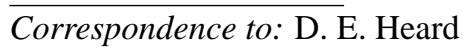

(dwayneh@chem.leeds.ac.uk) the marine boundary layer to date. This overview paper describes the aims of the NAMBLEX project in the context of previous field campaigns in the Marine Boundary Layer (MBL), the overall layout of the site, a summary of the instrumentation deployed, the temporal coverage of the measurement data, and the numerical models used to interpret the field data. Measurements of some trace species were made for the first time during the campaign, which was characterised by predominantly clean air of marine origin, but more polluted air with higher levels of $\mathrm{NO}_{\mathrm{x}}$ originating from continental regions was also experienced. This

Published by Copernicus GmbH on behalf of the European Geosciences Union. 
paper provides a summary of the meteorological measurements and Planetary Boundary Layer (PBL) structure measurements, presents time series of some of the longer-lived trace species $\left(\mathrm{O}_{3}, \mathrm{CO}, \mathrm{H}_{2}, \mathrm{DMS}, \mathrm{CH}_{4}, \mathrm{NMHC}, \mathrm{NO}_{\mathrm{x}}, \mathrm{NO}_{\mathrm{y}}\right.$, PAN) and summarises measurements of other species that are described in more detail in other papers within this special issue, namely oxygenated VOCs, HCHO, peroxides, organohalogenated species, a range of shorter lived halogen species $\left(\mathrm{I}_{2}, \mathrm{OIO}, \mathrm{IO}, \mathrm{BrO}\right), \mathrm{NO}_{3}$ radicals, photolysis frequencies, the free radicals $\mathrm{OH}, \mathrm{HO}_{2}$ and $\left(\mathrm{HO}_{2}+\Sigma \mathrm{RO}_{2}\right)$, as well as a summary of the aerosol measurements. NAMBLEX was supported by measurements made in the vicinity of Mace Head using the NERC Dornier-228 aircraft. Using ECMWF windfields, calculations were made of the air-mass trajectories arriving at Mace Head during NAMBLEX, and were analysed together with both meteorological and trace-gas measurements. In this paper a chemical climatology for the duration of the campaign is presented to interpret the distribution of air-mass origins and emission sources, and to provide a convenient framework of air-mass classification that is used by other papers in this issue for the interpretation of observed variability in levels of trace gases and aerosols.

\section{Introduction and background to NAMBLEX}

The hydroxyl radical $(\mathrm{OH})$, formed from the photolysis of ozone at wavelengths below $340 \mathrm{~nm}$ in the presence of water vapour, initiates the oxidation of almost all trace gases released into the marine boundary layer. Peroxy radicals $\left(\mathrm{HO}_{2}\right.$ $+\mathrm{RO}_{2}$ ) produced by this oxidation chemistry are responsible for ozone production or ozone destruction, depending upon the level of nitrogen oxides co-present. The oxidizing capacity of the troposphere is a combination of the above processes and others involving halogen and nitrate radicals. $\mathrm{NO}_{\mathrm{x}}\left(\mathrm{NO}+\mathrm{NO}_{2}\right)$ plays a crucial role in the free-radical oxidation chemistry associated with $\mathrm{OH}$ and $\mathrm{HO}_{2}$ radicals, halogen radical species (e.g. $\mathrm{IO}, \mathrm{BrO}$ ) and $\mathrm{NO}_{3} . \mathrm{NO}_{\mathrm{x}}$ is emitted directly into the atmosphere from various sources, both natural and anthropogenic, and is also formed in the atmosphere from the decomposition of other oxidised nitrogen compounds such as peroxy acetyl nitrate (PAN) and other organic nitrates. The source of $\mathrm{NO}_{\mathrm{x}}$ in the remote MBL is uncertain, one possibility being long-range transport of pollution, emissions from shipping, emissions from the ocean, or injection from the free troposphere either directly or in the form of reservoir compounds, many of which are associated with pollution. Increasing evidence suggests that the oxidizing capacity has been perturbed in recent years due to anthropogenic activity through emission of methane, carbon monoxide, non-methane hydrocarbons (NMHCs) and $\mathrm{NO}_{\mathrm{x}}$. These perturbations may be causing changes in the natural atmospheric composition, for instance increasing tropospheric concentrations of the greenhouse gas ozone, which has important implications for climate and human health. Any change in the oxidizing capacity of the atmosphere has many consequences for the long-term stability of the Earth's climate.

The MBL has been the venue for a large number of field campaigns, largely as it represents a location where pristinely clean air can be sampled that has had little or no perturbation due to anthropogenic activity, and the chemistry of the "natural" atmosphere can be interrogated. A summary of some of these campaigns can be found in Brasseur et al. (1999, 2002), Heard and Pilling (2003), and Holton et al. (2003). In addition Heard and Pilling (2003) provide a detailed list of a sub-set of field campaigns in the MBL that have included $\mathrm{OH}$ and $\mathrm{HO}_{2}$ measurements, together of course with a wide range of supporting measurements. The majority of observations have been made using ground-based instrumentation located at coastal sites, but measurements using instrumented ships or aircraft flying in the MBL above the open ocean in remote areas provide in situ measurements of atmospheric composition over a wider region. Recently, instruments on satellites combined with new retrieval methods have enabled the composition of the global troposphere to be determined from space for a limited number of species, for example for $\mathrm{CO}$, $\mathrm{O}_{3}, \mathrm{NO}_{2}, \mathrm{HCHO}, \mathrm{SO}_{2}, \mathrm{BrO}, \mathrm{CH}_{4}$ and some aerosol parameters, albeit averages over large footprints rather than point measurements.

Networks of instrumented ground-based sites in the remote MBL have been established by the World Meteorological Organisation Global Atmospheric Watch programme, the NOAA Climate Monitoring and Diagnostics Laboratory, and the Atmospheric Lifetime Experiment/Advanced Global Atmospheric Gases Experiment (ALE/AGAGE). These surface measurements have revealed distinctive seasonal and latitudinal patterns, as well as long-term trends, for several species, for example, $\mathrm{CO}, \mathrm{CO}_{2}, \mathrm{CH}_{4}, \mathrm{~N}_{2} \mathrm{O}, \mathrm{O}_{3}$, hydrocarbons, halogenated VOCs, aerosols and radiation. The chosen sites offer the best opportunity to sample air which is free from anthropogenic emissions, and in addition to the long-term monitoring programmes, short intensive field campaigns have been hosted by these sites using significant additional instrumentation to measure a large number of trace gas, aerosols and radiative parameters, to enable a detailed investigation of the underlying chemistry. Examples include the Southern Ocean Atmospheric Photochemistry Experiments (SOAPEX) at Cape Grim (Monks et al., 1998; Sommariva et al., 2004), the Eastern Atlantic Summer/Spring Experiments (EASE)(Carslaw et al., 2002, 1999a) and the New Particle Formation and Fate in the Coastal Environment (PARFORCE) campaign (O'Dowd et al., 2002b, 2004) at Mace Head. However, even at remote sites, the background chemistry is perturbed, with calculated air mass back trajectories showing encounters with sources of anthropogenic emission several days prior to arrival. During long-range transport to the site oxidation of primary emissions into a variety of secondary species, for example, oxygenated VOCs, 
$\mathrm{O}_{3}$ and aerosols, can significantly modify the chemistry of shorter-lived species, for example, the hydroxyl radical, at the measurement site. One also has to be careful of local anthropogenic emissions, that may become problematic under certain meteorological conditions. Hence intensive field campaigns are usually of 1-2 months duration in the hope that for some of the time, at least, local sources do not influence, and the trajectory of the sampled air is relatively free from anthropogenic input. During a period of 1-2 months, a range of air-masses is usually encountered, allowing the effect, for example, of changing $\mathrm{NO}_{\mathrm{x}}$ or hydrocarbons, and the underlying chemistry, to be investigated (Carslaw et al., 2002).

The North Atlantic Marine Boundary Layer Experiment (NAMBLEX), funded by the UK Natural Environment Research Council, took place at Mace Head during the summer of 2002, with the aim of studying the detailed chemistry of the MBL. This special issue of Atmospheric Chemistry and Physics contains a series of papers dedicated to field measurements and model comparisons from NAMBLEX. The full list of papers can be found in Appendix A of this paper. The campaign, which ran from 23 July until 4 September 2002, involved approximately 50 scientists from 13 institutions: The Universities of Leeds, York, East Anglia (UEA), Leicester, Aberystwyth, Manchester, Cambridge, Bristol, Birmingham, Edinburgh and Reading from the UK, and The National University of Ireland (NUI), Galway and TNO Physics and Electronics, The Netherlands. The project is an extension of the UK consortium that had previously mounted field campaigns in the MBL during the Eastern Atlantic Summer Experiment 1996 (EASE96) (Allan et al., 1999; Carslaw et al., 2000, 1999b; Evans et al., 2000; Grenfell et al., 1999; Lewis et al., 1999) the Eastern Atlantic Spring Experiment 1997 (EASE97) (Creasey et al., 2002; Salisbury et al., 2001, 2002; Savage et al., 2001; Monks et al, 2000; Rickard et al., 2002), and the Southern Ocean Atmospheric Photochemistry Experiments (SOAPEX-1, 2) at Cape Grim, Tasmania (Carpenter et al., 1997; Creasey et al., 2003; Haggerstone et al., 2005; Lewis et al., 2001; Monks et al., 1998, 1996; Sommariva et al., 2004). During these campaigns, measurements were made of the free radicals $\mathrm{OH}$, $\mathrm{HO}_{2}, \mathrm{RO}_{2}, \mathrm{NO}_{3}$, IO and OIO over a wide range of $\mathrm{NO}_{\mathrm{x}}$, together with continuous multi-species NMHC measurements at the $\geq 1$ pptv level for alkanes, alkenes and aromatics, including diurnal profiles, and source identification. Shortlived reactive halogenated hydrocarbons were found to act as sources of halogen radicals, and co-measurements of $\mathrm{OH}$, DMS and a wide-range of aerosol parameters were used to suggest a preliminary mechanism for the formation of ultrafine particles.

Although the previous campaigns were highly successful, they raised further questions, including the factors responsible for determining the oxidizing capacity. For example, discrepancies were observed between modelled and measured $\mathrm{OH}$ and $\mathrm{HO}_{2}$ concentrations, perhaps due to chemical links between the hydrogen $\left(\mathrm{HO}_{\mathrm{x}} / \mathrm{RO}_{\mathrm{x}}\right)$ and halogen $\left(\mathrm{XO}_{\mathrm{x}}\right)$ families of radicals included in mechanisms used to model the chemistry. The source of $\mathrm{NO}_{\mathrm{x}}$, the role of night-time oxidants, the nature of aerosols and their role in mediating heterogeneous chemistry, the internal mixture of particles making up the marine atmospheric aerosol and the processes which give rise to new particle creation were also outstanding questions.

There were several objectives of the NAMBLEX campaign.

(1) To compare concentration measurements of a wide range of short-lived free-radicals $\left(\mathrm{OH}, \mathrm{HO}_{2}, \mathrm{RO}_{2}, \mathrm{NO}_{3}\right)$ with the calculations of a zero-dimensional model, that used the detailed Master Chemical Mechanism (Jenkin et al., 2003), to test quantitatively the basic understanding of oxidation processes in clean and moderately polluted air in the MBL. The number of free-radical sources and sinks measured during NAMBLEX and used to constrain the model was considerably larger than for previous campaigns at Mace Head. Examples of new measurements include oxygenated hydrocarbons beyond $\mathrm{HCHO}$, which have a relatively long lifetime and can be transported to the site, and the measurement of a very wide range of photolysis frequencies, e.g. $j$-(HCHO), rather than just $j-\left(\mathrm{O}^{1} \mathrm{D}\right)$ and $j-\left(\mathrm{NO}_{2}\right)$.

(2) To study extensively the chemistry of halogen species in the MBL, and the links with $\mathrm{HO}_{\mathrm{x}}$, through observation of reactive intermediates and their sources and sinks, and comparison with model calculations. This was facilitated by a number of new measurements, for example molecular iodine, $\mathrm{I}_{2}$, and BrO radicals, as well as IO, OIO, organic halogenated species, and halogens in the aerosol phase.

(3) To study the reactive nitrogen budget over the Atlantic Ocean, through highly detailed measurements of $\mathrm{NO}_{\mathrm{x}}, \mathrm{NO}_{\mathrm{y}}$ (NO, $\mathrm{NO}_{2}, \mathrm{HNO}_{3}, \mathrm{NO}_{3}$, alkyl nitrates, PAN all measured) and nitrate observed in the particulate phase as a function of aerosol diameter.

(4) To examine the origins and role of reactive hydrocarbons in the MBL. Distinct diurnal cycles had previously been observed at Mace Head for reactive hydrocarbons, for example, isoprene and other alkenes.

(5) To investigate the size-distributed composition, internal mixing and hygroscopicity of aerosols and the processes involved in new particle creation and the production of sea spray aerosol. Atmospheric aerosols, through their radiative properties and effect on cloud formation, play a key role in moderating the global warming expected to result from increases in greenhouse gases, and hence a clear understanding of their formation, evolution and fate is essential. Composition measurements were made as a function of particle size in real time using two aerosol mass spectrometric methods. These instruments made qualitative mass spectral analysis of individual particles and quantitative mass distributions of individual components within the ensemble particle population, at vastly greater time resolution than is possible with bulk sampling methods. Bursts of nanoparticles 
were observed during the EASE and PARFORCE campaigns (O'Dowd et al., 1999, 2002a), but the mechanism of production was still unclear, and additional measurements of halogen intermediates, e.g. OIO, a potential nucleating species, and $\mathrm{I}_{2}$, were used in NAMBLEX to assemble a new model of particle production. Investigations on the primary production of sea spray aerosol were made using a flux package consisting of a sonic anemometer, condensation particle counter (CPC) and an optical particle counter with a heated inlet, following methods described in Nilsson et al., (2001) and De Leeuw et al., (2003).

The design of the 2002 NAMBLEX campaign took into account lessons learned during the previous EASE 96 and 97 campaigns held at Mace Head. The instruments whose measurements were required to constrain the zero-dimensional model were co-located in five instrumented shipping containers, or permanent buildings, all at the shore site (see Sect. 2 below), so that differences in air mass composition between different parts of the site were no longer a valid reason to explain poor agreement between measured and modelled free radicals. Other distinguishing features of NAMBLEX compared with previous deployments were the close interaction between atmospheric physicists, who made highly detailed measurements of boundary layer structure, and atmospheric chemists making composition measurements, and the sustained exposure to westerly winds, ensuring that very clean air was sampled for the majority $(80 \%)$ of the campaign. Several species were measured using more than one instrument, enabling intercomparisons to be performed.

The remainder of the overview paper is organised as follows. Section 2 contains a description of the site, a summary of the meteorological conditions encountered and the boundary layer structure measurements, and contains a detailed listing of the instrumentation and models used. Section 3 gives an overview of the data and shows time-series for measurements of the longer-lived species measured, for example $\mathrm{O}_{3}, \mathrm{CO}, \mathrm{H}_{2}$, DMS, $\mathrm{CH}_{4}, \mathrm{NMHC} \mathrm{NO}_{\mathrm{x}}, \mathrm{NO}_{\mathrm{y}}$, PAN, which are not discussed in detail in other papers. A summary is also given of the measurement methods used for other species whose measurements are covered in detail in other papers within this special issue, namely oxygenated VOCs, $\mathrm{HCHO}$, peroxides, organo-halogenated species, a range of shorter lived halogen species $\left(\mathrm{I}_{2}, \mathrm{OIO}, \mathrm{IO}, \mathrm{BrO}\right), \mathrm{NO}_{3}$ radicals, photolysis frequencies, the free radicals $\mathrm{OH}, \mathrm{HO}_{2}$ and $\left(\mathrm{HO}_{2}+\Sigma \mathrm{RO}_{2}\right)$, as well as a summary of the aerosol measurements and the supporting aircraft campaign. In Sect. 4 the meteorological climatology for the duration of the campaign is summarised, and in Sect. 5 a trajectory analysis of sampled air masses is presented. In Sect. 6 a chemical climatology for the duration of the campaign is presented to rationalise the distribution of air mass origins and emission sources, and to provide a convenient framework of air mass classification that is used by other papers in this issue for the interpretation of observed variability in levels of trace gases and aerosols. In Sect. 7 the conditions during NAMBLEX are compared with those encountered in other campaigns at Mace Head. This paper does not attempt to summarise the major scientific results from the campaign, rather these are discussed in a separate summary paper at the end of the special issue Heard (2006).

\section{Description of site, measurements and model activi- ties}

Remotely situated on the Atlantic coast of Ireland $\left(53.32^{\circ} \mathrm{N}\right.$, $9.90^{\circ} \mathrm{W}$ ) about $90 \mathrm{~km}$ west of Galway (Fig. 1a), the Mace Head Atmospheric Research Station (referred to simply as Mace Head in this paper) is ideally positioned to receive air from a wide range of sources (Cape et al., 2000). The site is mainly characterised by conditions of exceptionally clean air which has source regions extending as far south as the Azores and as far north as Greenland. Contrastingly however, air originating in continental Europe and west/northwest America although more infrequent (Derwent et al., 1998), has allowed investigation into the long-range transport of anthropogenic precursors to pollutant species observed at the site and the subsequently enhanced ozone levels (Methven et al., 2001; Simmonds et al., 1997). The prevailing wind direction is from $180^{\circ}-300^{\circ}$ ( $52 \%$ of the time (Jennings et al., 2003)) during which the air has often travelled over the Atlantic Ocean for the five days before its arrival at Mace Head and so can be considered representative of background conditions for the Northern Hemisphere. The climate is mild and moist (Relative Humidity on average $80-85 \%$ and average summer temperature (June-September) of $15^{\circ} \mathrm{C}$ ), in line with its coastal position, with the months of October through to January suffering from the most rainfall.

Mace Head is one of several stations which make up the Global Atmosphere Watch (GAW) program of the World Meteorological Organisation (http://www.wmo.ch/web/arep/ gaw/gawhome.html) and the AGAGE (Advanced Global Atmospheric Gases Experiment) program (http://agage.eas. gatech.edu/) (Derwent et al., 1994; Simmonds et al., 1997). Continuous measurements of trace gases such as CFCs, $\mathrm{CCl}_{4}, \mathrm{CH}_{4}, \mathrm{~N}_{2} \mathrm{O}, \mathrm{CO}$, and $\mathrm{O}_{3}$ have been made since 1987 contributing to the European Tropospheric Ozone Research (TOR) network, in addition to a long-term flask sampling network which has been established in collaboration with NOAA Climate Monitoring and Diagnostics Laboratory (CMDL) specifically for the measurement of $\mathrm{CO}_{2}$ and isotopes.

The shore site consists of two permanent instrumented buildings (A and B, panel b, Fig. 1, roofed structures in Fig. 2), two walk-up towers ( $23 \mathrm{~m}$ and $10 \mathrm{~m}$ ) situated $100 \mathrm{~m}$ from the shoreline at high tide (10 $\mathrm{m}$ above sea level (a.s.l.)), and a third instrumented building at the top site $300 \mathrm{~m}$ from the shoreline at high tide ( $25 \mathrm{~m}$ a.s.l.), from which the photograph in Fig. 2b was taken. In contrast to the EASE96 and 97 campaigns, where instruments were split between the 

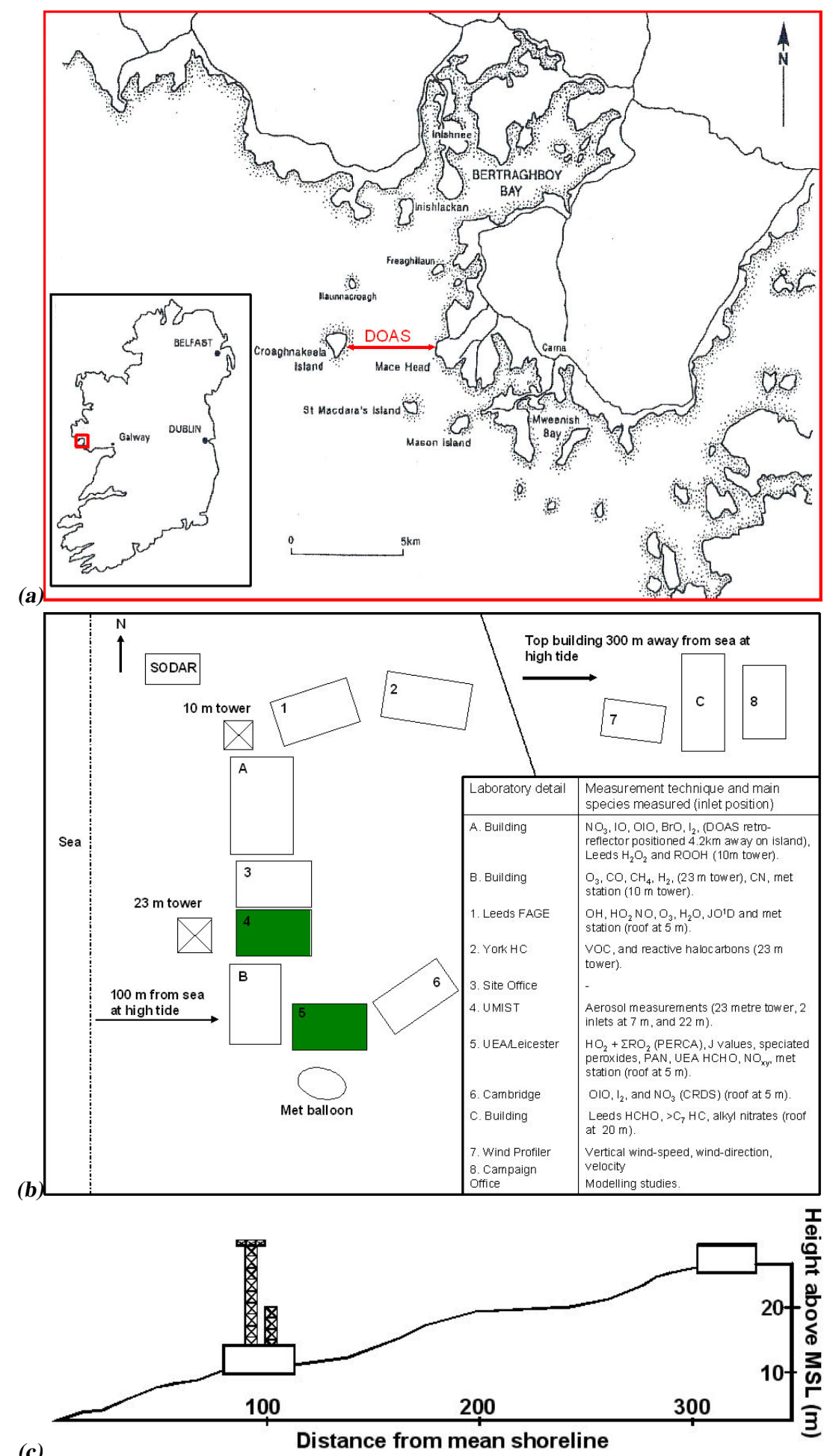

Fig. 1. (a): A map of the Connemara region (Ireland inset) showing the Mace Head site and Croaghnakeela island where the DOAS retromirror was situated. (b): A plan of the site showing the position of the permanent buildings, containers, instruments, sampling towers and sampling points for each measurement, (c): Side view of site. 
shore and top site (separated by $200 \mathrm{~m}$ ), (Carslaw et al., 2000, 2002) during NAMBLEX the majority of instruments were positioned within a radius of $10-20 \mathrm{~m}$ of the common tower sampling points, either inside the shore buildings or within a variety of newly commissioned containers (panel b, Fig. 1, and Fig. 2b). The surrounding area consists of moorland with areas of exposed granite rock and little vegetation except for grasses, heather, ferns, rushes and gorse (as shown in Fig. 2a). The ground is generally wet and boggy (annual rainfall $1200 \mathrm{~mm}$ ) and mainly made up of shallow peaty soils. At low tides there are exposed seaweed beds which act as a significant source of halogenated species (Carpenter et al., 2003, 1999; McFiggans et al., 2004).

\subsection{Wind speed and direction}

Local wind direction and wind speed measurements were made at Mace Head by the National University of Ireland (NUI), Galway, the University of Leeds and the University of Leicester using standard meteorological stations (including wind vanes and anemometers). The first of these took measurements from the top of the $10 \mathrm{~m}$ tower whilst the latter two were positioned on the top of their respective containers (5 m height) (Figs. 1, 2) and so suffered some minor interference from the permanent buildings. For the most part the local wind direction was between $180^{\circ}$ and $300^{\circ}$ except for a north easterly period from 31 July to 5 August, and a north westerly period between the 24 to 26 August. These periods are addressed in more detail in the discussion of trajectories in Sect. 6. The wind speed during the campaign varied from 0.5 to $15 \mathrm{~ms}^{-1}$, with the highest wind speeds observed on the 11 August during a period of north westerly conditions.

\subsection{Relative humidity and temperature}

Both relative humidity and air temperature measurements were made by NUI, Galway from the $10 \mathrm{~m}$ tower (panel $\mathrm{b}$, Fig. 1) using a Vaisala HMD-30YB humidity sensor. During NAMBLEX the campaign averages $\pm 1 \sigma$ for temperature and relative humidity were $15.2 \pm 1.3^{\circ} \mathrm{C}$ and $85.7 \pm 8.7 \%$, respectively. These are consistent with the average measurements for relative humidity of between $80-85 \%$ and summer temperature of $15^{\circ} \mathrm{C}$ for Mace Head (http://macehead.physics. nuigalway.ie/).

\subsection{Planetary boundary layer (PBL) structure}

The height of the PBL over land displays a diurnal cycle due to changes in surface heating by the sun, and typically is characterised by a maximum during the day and a minimum, stable value at night. An Ultra High Frequency (UHF) wind profiler, four 3-axis sonic anemometers and a Doppler Sodar (Sonic Detection and Ranging) provided vertically resolved measurements of wind direction and wind speed from the surface to $3 \mathrm{~km}$, which were used to derive a number of parameters, for example the degree of turbulence and the diurnal variation of the boundary layer height. Although tethered balloons and radiosondes have previously been used at Mace Head to determine boundary layer height (Carslaw et al., 2002), this was the first time a wind profiler had been deployed at Mace Head to make continuous measurements. During NAMBLEX the PBL structure at Mace Head was "typical" only on a few select days, with evidence of coastal features, for example sea-breezes and the formation of an internal boundary layer, which could impact on the interpretation of the chemical measurements. These measurements are presented in detail in the next paper (Norton et al., 2006), which highlights any differences in the local wind direction and that of the synoptic flow and trajectories calculated using ECMWF analyses, which must be considered carefully when interpreting the observed concentrations of trace species.

\subsection{Species measured during NAMBLEX and data cover- age}

Trace gas measurements included $\mathrm{OH}$, and $\mathrm{HO}_{2}$, and total peroxy (hydro and organic) radicals $\mathrm{HO}_{2}+\Sigma \mathrm{RO}_{2}, \mathrm{NO}_{3}$, $\mathrm{IO}, \mathrm{OIO}, \mathrm{BrO}, \mathrm{I}_{2}, \mathrm{O}_{3}, \mathrm{NO}, \mathrm{NO}_{2}, \Sigma \mathrm{NO}_{\mathrm{y}}\left(\mathrm{NO}+\mathrm{NO}_{2}+\mathrm{NO}_{3}\right.$, $\mathrm{HONO}+\mathrm{HNO}_{3}+\mathrm{HO}_{2} \mathrm{NO}_{2}+\mathrm{N}_{2} \mathrm{O}_{5}+\mathrm{PAN}+$ organic nitrates), alkyl nitrates, PAN, speciated peroxides, $\mathrm{HCHO}, \mathrm{CO}, \mathrm{CH}_{4}$, $\mathrm{H}_{2} \mathrm{O}$, NMHC, and some selected o-VOCs. Measurements of spectrally-resolved actinic flux using a spectral-radiometer were used to calculate photolysis frequencies. In addition, several of these species $\left(\mathrm{O}_{3}, \mathrm{HCHO}\right.$, NMHC, halocarbons, and peroxides) were measured by more than one technique/group allowing intercomparisons to be made. Prior to this study little was known of the role of aerosols in modifying the oxidative capacity through heterogeneous uptake of free radicals, and detailed measurements were made of aerosol size distribution, chemical composition and condensation nuclei $(\mathrm{CN})$ using state-of-the-art techniques. Table 1 lists all the species measured during NAMBLEX, including radiation and boundary layer structure, and the corresponding technique(s) used, with detection limits and integration periods. Figure 3 summarises the temporal coverage of the measurements for each individual species throughout the campaign. Full data are available from http://badc.nerc.ac.uk/data/namblex/.

\subsection{Modelling activities}

A key NAMBLEX objective was to compare measured concentrations of the short-lived free radicals, for example $\mathrm{OH}$, $\mathrm{HO}_{2}, \mathrm{HO}_{2}+\Sigma \mathrm{RO}_{2}, \mathrm{NO}_{3}, \mathrm{IO}$ and $\mathrm{BrO}$, as well as longer-lived but photochemically generated species, for example $\mathrm{HCHO}$, with the predictions of zero-dimensional models that considered only in situ chemistry and no transport processes. The model was constrained with a large number of trace species and radiative parameters, co-measured during NAMBLEX, which are either sources or sinks for these species, 


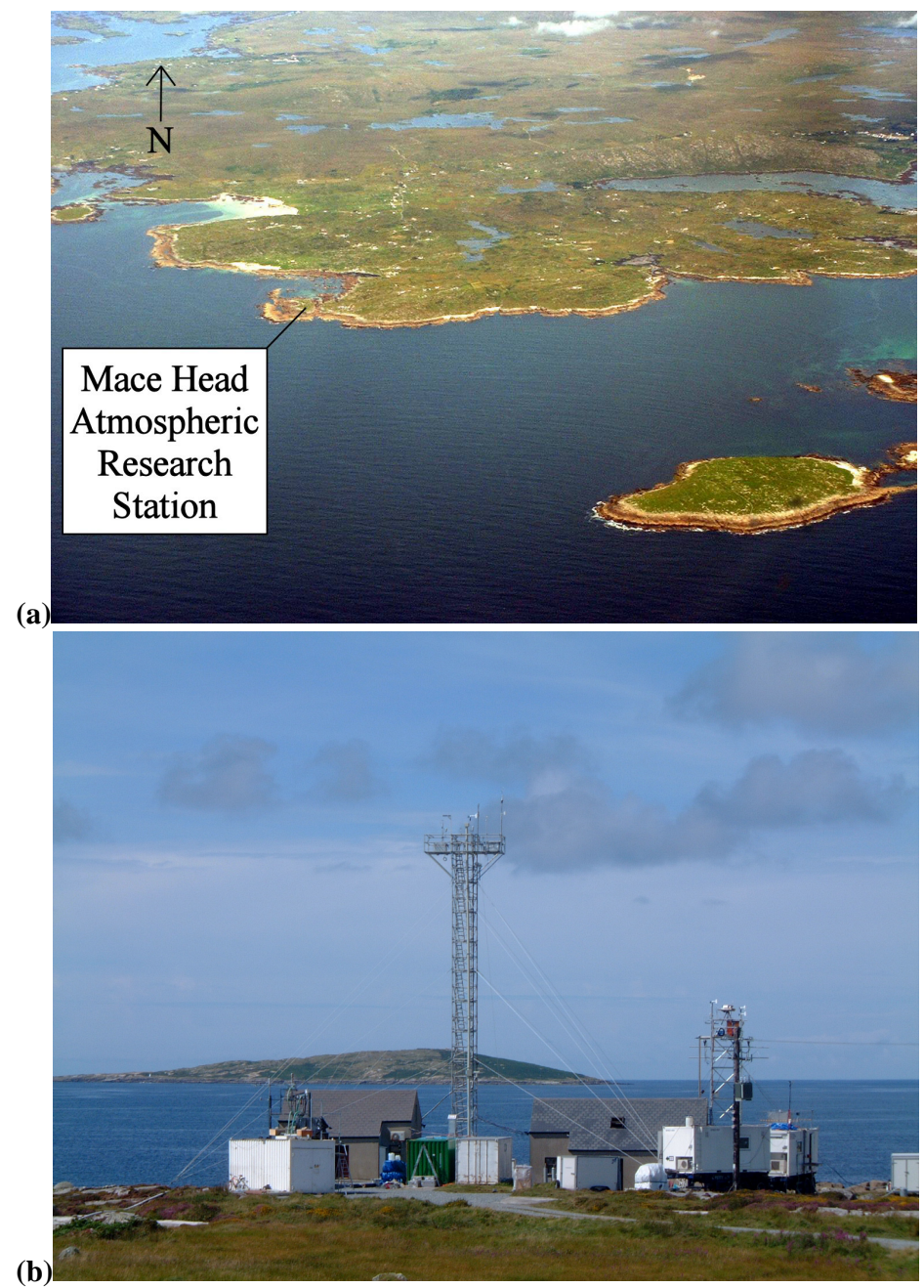

Fig. 2. (a): Aerial photograph, looking north, of the Mace Head area (taken by R. M. Purvis). (b): View, looking west, of the shore site with Croagnakeela island in the background, where the DOAS retro-reflector was situated (taken by D. E. Heard). From right to left, the visible shipping containers are numbers 1 (white), 2 (white), 3 (white), 4 (green), and 6 (white), as given in Fig. 1. Shipping container 5 (green) is directly behind container 6 and is not visible. and therefore define their budget. In this manner the accuracy of any chemical mechanisms could be tested. For the calculation of $\mathrm{HO}_{\mathrm{x}}, \mathrm{RO}_{\mathrm{x}}$ and $\mathrm{NO}_{3}$, a number of "campaign tailored" mechanisms of varying chemical complexity, were derived from the Master Chemical Mechanism (MCM) (Jenkin et al., 1997), which in its full form consists of $\sim 13500$ reactions and $\sim 5600$ species and describes the oxidation of 135 VOCs by $\mathrm{OH}, \mathrm{NO}_{3}$ and $\mathrm{O}_{3}$ all the way through to $\mathrm{CO}_{2}$ and $\mathrm{H}_{2} \mathrm{O}$ vapour. The mechanism is explicit and does not lump species together, using structural activity relationships where kinetic data are not available. The MCM has been used previously for field campaigns in the MBL (Carslaw et al., 2002, 1999b; Sommariva et al., 2004). The mechanisms used vary from a simple mechanism considering only $\mathrm{CO}$ and $\mathrm{CH}_{4}$ oxidation, all the way through to the oxidation of all measured hydrocarbons and o-VOCs, including the chemistry of halogen monoxides (IO and BrO). (Sommariva et al., 2005a and 2005b; Fleming et al., 2005). A detailed and rigorous methodology was developed to calculate the heterogeneous loss rates, which made full use of the aerosol size-distribution and composition measurements (Sommariva et al., 2005a). The free radical chemistry during both the night and daytime is discussed.

The MCM was embedded into a trajectory model and used to investigate the contribution of secondary production of oVOCs to the concentrations observed at Mace Head during NAMBLEX. The precursor NMHCs were initialised with anthropogenic emissions representative of a continental landmass and allowed to chemically evolve over a period of 10 days simulating the transport across the Atlantic (Lewis et al., 2005). In this manner the fraction of the observed oVOCs from in situ oxidation at Mace Head compared with long-lived transport could be investigated, although no efforts were made to reproduce actual concentrations.

Through the use of the gas-phase measurements of DMS and methanol, in conjunction with their respective windinduced turbulent gas transfer velocities calculated from a resistance model within a photochemical box model, an estimation for the uptake of methanol to the ocean was also established (Carpenter et al., 2004). 


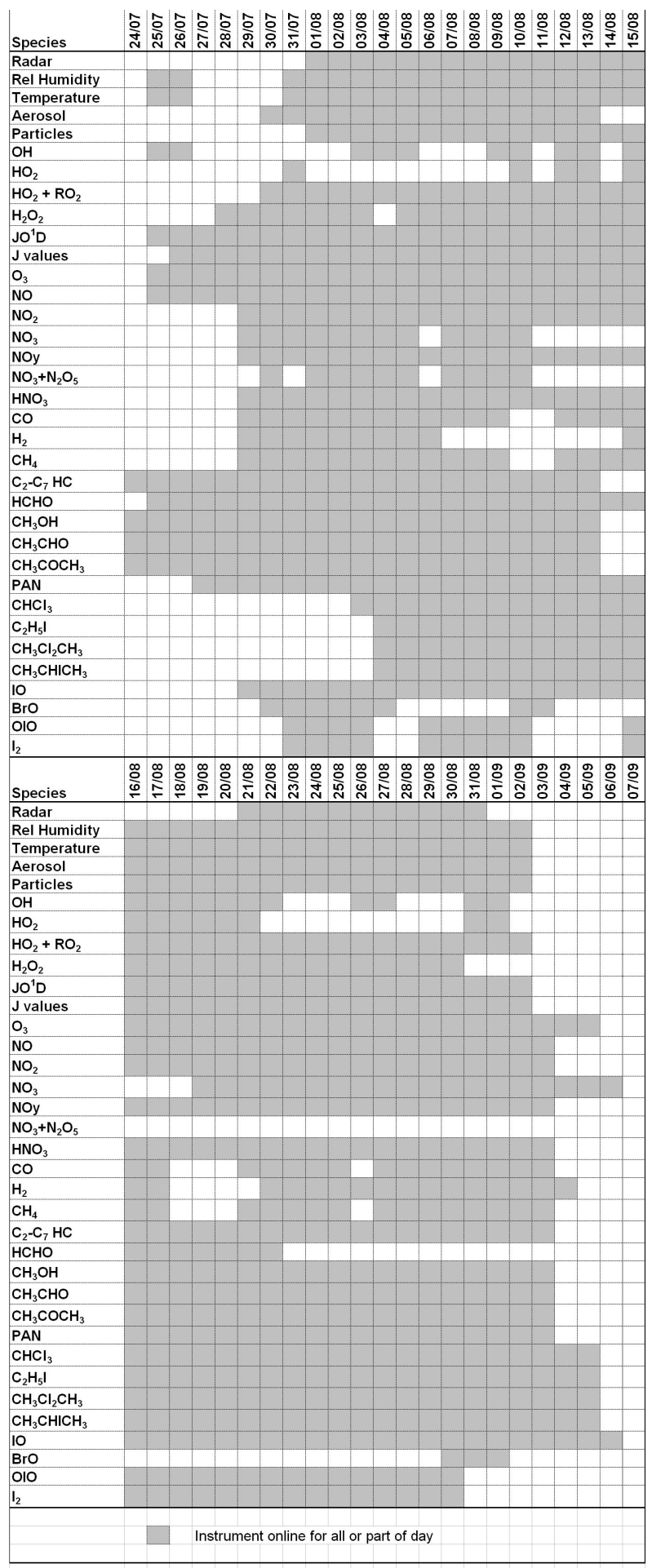

Fig. 3. Time-line showing data coverage for the NAMBLEX campaign, 2002.

A much simpler approach was used by Smith et al. (2006) to rationalise the observed concentrations of $\mathrm{OH}$ and $\mathrm{HO}_{2}$ radicals. A number of analytically explicit steady state expressions were constrained by co-measured sources and sinks and used to calculate $\mathrm{OH}$ and $\mathrm{HO}_{2}$ concentrations. This meant that the effect of individual species, for example reactions of halogen oxides with $\mathrm{HO}_{2}$ or heterogeneous uptake of $\mathrm{HO}_{2}$ onto aerosols could be investigated. 
Table 1. Species measured and instruments deployed during the NAMBLEX field experiment, Mace Head, Ireland, in July-September 2002.

\begin{tabular}{|c|c|c|c|c|c|}
\hline Species measured & Analytical technique & Temporal resolution & Detection limit & Measurement Uncertainty & Reference in this issue \\
\hline $\mathrm{OH}$ & Fluorescence Assay by Gas Expansion (FAGE) & $30 \mathrm{~s}$ & $\begin{array}{l}1.9 \times 10^{5} \text { molecule } \mathrm{cm}^{-3} \\
(300 \mathrm{~s}), 0.007 \mathrm{pptv}\end{array}$ & $22 \%( \pm 1 \sigma)$ & Smith et al. (2006) \\
\hline $\mathrm{HO}_{2}$ & Addition of $\mathrm{NO}$ to convert to $\mathrm{OH}$, then FAGE & $30 \mathrm{~s}$ & $\begin{array}{l}2.9 \times 10^{6} \text { molecule } \mathrm{cm}^{-3} \\
(300 \mathrm{~s}) 0.12 \mathrm{pptv}\end{array}$ & $25 \%( \pm 1 \sigma)$ & Smith et al. (2006) \\
\hline$\Sigma \mathrm{RO}_{2}+\mathrm{HO}_{2}$ & Peroxy Radical Chemical Amplifier (PERCA) & $1 \mathrm{~min}$ & $0.4 \mathrm{pptv}(10 \mathrm{~min})$ & $38 \%( \pm 1 \sigma)$ & Fleming et al. (2005) \\
\hline $\mathrm{NO}_{3}, \mathrm{IO}, \mathrm{OIO}, \mathrm{BrO}, \mathrm{I}_{2}$ & Differential Optical Absorption Spectroscopy, optical path $2 \times 4.2 \mathrm{~km}$ & $30 \mathrm{~min}$ & $0.5,0.8,3,1,5 \mathrm{pptv}$ & $0.6,0.9,2.5,1,4.5 \mathrm{pptv}$ & Saiz-Lopez et al. (2006a, b) \\
\hline $\mathrm{NO}_{3}, \mathrm{OIO}, \mathrm{I}_{2}$ & Broadband cavity ringdown spectroscopy & $100 \mathrm{~s}, 10,10 \mathrm{~min}$ & $1,4,20 \mathrm{pptv}$ & $1-2,4-10,20-40 \mathrm{pptv}$ & Bitter et al. $\left(2005,2006^{1}\right)$ \\
\hline Vertical profiles of $\mathrm{NO}_{3}$ & Zenith-pointing DOAS and altitude retrieval & 1 profile / day & $(1-5) \times 10^{13}$ molecule $\mathrm{cm}^{-2}$ & & Saiz-Lopez et al. (2006b) \\
\hline Aerosol optical extinction at 660 or $570 \mathrm{~nm}$ & Broadband cavity ringdown spectroscopy & $2 \min$ & $5 \times 10^{-4} \mathrm{~km}^{-1}$ & $5 \times 10^{-9} \mathrm{~cm}^{-1}$ & Bitter et al. (2006) ${ }^{1}$ \\
\hline \multirow[t]{2}{*}{ Photolysis frequencies, including $j$ - $\left(\mathrm{O}^{1} \mathrm{D}\right), j$-( $\left(\mathrm{NO}_{2}\right)$} & Calibrated filter radiometers & $1 \mathrm{~min}$ & & $12 \%$ and $11 \% 0-90^{\circ} \mathrm{SZA}$ & Heard et al. (2006) \\
\hline & Diode array spectral-radiometer $(2 \pi \mathrm{sr})$ & $1 \mathrm{~min}$ & & $14 \%$ and $13 \% 0-90^{\circ} \mathrm{SZA}$ & Heard et al. (2006) \\
\hline $\mathrm{O}_{3}$ & UV absorption spectroscopy & $1 \mathrm{~s}$ & $0.6 \mathrm{ppbv}$ & 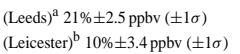 & $\begin{array}{l}\text { Heard et al. (2006) } \\
\text { Heard et al. (2006) }\end{array}$ \\
\hline NO & $\mathrm{NO} / \mathrm{O}_{3}$ chemiluminescence detectors & $10 \mathrm{~s}$ & $1 \mathrm{pptv}$ & $25 \%$ at $450 \mathrm{pptv}$ & Heard et al. (2006) \\
\hline $\mathrm{NO}_{2}$ & Photochemical convertor $\mathrm{NO}_{2} \rightarrow \mathrm{NO}$ & & $2 \mathrm{pptv}$ & $25 \%$ at $450 \mathrm{pptv}$ & Heard et al. (2006) \\
\hline$\Sigma \mathrm{NO}_{\mathrm{y}}$ & Gold tube/ $\mathrm{CO}$ converter $\mathrm{NO}_{\mathrm{y}} \rightarrow \mathrm{NO}$ & & $5 \mathrm{pptv}$ & $15-20 \%$ at $450 \mathrm{pptv}$ & Heard et al. (2006) \\
\hline $\mathrm{H}_{2} \mathrm{O}_{2}, \mathrm{CH}_{3} \mathrm{OOH}$ & Scrubbing/derivatisation, High performance liquid chromatography & $8 \mathrm{~min}$ & $10 \mathrm{pptv}$ & & Jackson et al. $(2006)^{2}$ \\
\hline $\mathrm{H}_{2} \mathrm{O}_{2}, \Sigma \mathrm{ROOH}$ & Dual-channel fluorometric detector & $20 \mathrm{~s}$ & $10 \mathrm{pptv}$ & & Jackson et al. $(2006)^{2}$ \\
\hline $\mathrm{H}_{2} \mathrm{O}$ vapour & IR absorption; from RH data, and Broadband cavity ringdown spectroscopy & $10 \mathrm{~s}$ & 5 ppmv & $3 \%$ & $\begin{array}{l}\text { Heard et al. }(2006) \\
\text { Bitter et al. }\left(2005,2006^{1}\right)\end{array}$ \\
\hline НСНо & $\begin{array}{l}\text { Fluorometric detection (Hantzsch reaction) } \\
\text { Selective trapping and gas chromatography/helium ionization detection }\end{array}$ & $\begin{array}{l}1 \mathrm{~min} \\
5.5 \mathrm{~min}\end{array}$ & $\begin{array}{l}50 \mathrm{pptv} \\
42 \mathrm{pptv}\end{array}$ & $13 \%,>25 \mathrm{pptv} 6 \%$ & Still et al. (2005) \\
\hline $\begin{array}{l}\text { Speciated } \mathrm{C}_{2}-\mathrm{C}_{7} \mathrm{NMHC} \\
\text { including isoprene, DMS }\end{array}$ & $\begin{array}{l}\text { Automated GC/ flame ionization detection using } \\
\text { programmed temperature injection } \\
\text { Seawater sampling using head-space GC }\end{array}$ & $40 \mathrm{~min}$ & 1 pptv & $<10 \mathrm{pptv}$ & Lewis et al. (2005) \\
\hline $\mathrm{CH}_{3} \mathrm{OH},\left(\mathrm{CH}_{3}\right)_{2} \mathrm{CO}, \mathrm{CH}_{3} \mathrm{CHO}$ & $\begin{array}{l}\text { Gas chromatography with flame ionization detection, } \\
\text { selective column for oxygenates }\end{array}$ & $40 \min$ & 1 pptv & $<20 \mathrm{pptv}$ & Lewis et al. (2005) \\
\hline Peroxy acetyl nitrate (PAN) & Gas chromatography / electron capture detection & $5 \min$ & $10 \mathrm{pptv}$ & $19 \%,>7 \mathrm{pptv} 11 \%$ & Heard et al. (2006) \\
\hline Alkyl nitrates & $\begin{array}{l}\text { Negative ion chemical ionisation } \\
\text { gas chromatography/mass spectrometry }\end{array}$ & $45 \mathrm{~min}$ & $\begin{array}{l}<0.1 \mathrm{pptv}_{1}-\mathrm{C}_{3} \\
<0.5 \mathrm{pptv} \mathrm{C}_{4}\end{array}$ & $\begin{array}{l}30 \% \\
50 \%\end{array}$ & \\
\hline Reactive halocarbons & Gas chromatography/mass spectrometry & $40 \mathrm{~min}$ & $<0.2 \mathrm{pptv}$ & $15 \%$ & Carpenter et al. (2005) \\
\hline $\begin{array}{l}\text { Aerosol number and size } \\
\text { distributions ( } 3 \mathrm{~nm} \text { to } 20 \mu \mathrm{m})\end{array}$ & $\begin{array}{l}\text { Scanning mobility particle sizer }(3-500 \mathrm{~nm}) \\
\text { range of optical particle counters }(0.1-300 \mu \mathrm{m}), \mathrm{CN} \text { counters, }(>3,5,10 \mathrm{~nm})\end{array}$ & $1 \mathrm{~min}$ & & & Coe et al. (2005) \\
\hline \multirow[t]{3}{*}{ Aerosol chemical composition, volatility } & Aerosol mass spectrometer (Aerodyne Inc.) $\left(\mathrm{NH}_{4}^{+}, \mathrm{Na}^{+}, \mathrm{Cl}^{-}, \mathrm{SO}_{4}^{2-}\right.$ ) & $0.05 \mathrm{~s}$ & $\begin{array}{l}100 \text { particles } \mathrm{s}^{-1}\left(0.25 \mu \mathrm{g} \mathrm{m}^{-3}\right) \\
\text { for a } 3 \text { min ave }\end{array}$ & & Coe et al. (2005) \\
\hline & Aerosol time of flight mass spectrometer (TSI Inc.) & $1 \mathrm{~h}$ & & & Dall'Osto et al. (2005) \\
\hline & Cascade impactors (filters) with ion chromatography & $\begin{array}{l}24 \mathrm{~h} \text { (component } \\
\text { dependent) }\end{array}$ & & & \\
\hline Vertically resolved wind-speed and direction & UHF Wind profiler $0.2-5 \mathrm{~km}$, (Doppler radar) Sodar $(10-200 \mathrm{~m}$ ), tethered balloon & $15 \mathrm{~min}$ & & & Norton et al. (2006) \\
\hline$u, v, w$ wind velocity & Sonic anemometers & $0.1 \mathrm{~s}$ & & & Norton et al. (2006) \\
\hline $\mathrm{CO}$ & $\begin{array}{l}\mathrm{GC} / \text { hot mercuric oxide reduction gas detector coupled with } \\
\mathrm{UV} \text { detection GC/flame ionization detector }\end{array}$ & $40 \min$ & & $2 \%( \pm 1 \sigma)$ & Heard et al. (2006) \\
\hline $\mathrm{CO}_{2}$ (in situ) & Non-dispersive infrared spectroscopy & $2 \mathrm{~h}$ & & & \\
\hline CFCs, HCFCs, HFCs & Gas chromatography / electron capture detector / mass spectrometer & $2 \mathrm{~h}$ & $<1 \mathrm{pptv}$ & & \\
\hline $\mathrm{H}_{2}$ & $\begin{array}{l}\text { Gas chromatography/hot mercuric oxide reduction gas } \\
\text { detector coupled with UV detection }\end{array}$ & $40 \mathrm{~min}$ & & & Heard et al. (2006) \\
\hline $\mathrm{CH}_{4}$ & Gas chromatography / Flame ionization detector & $40 \min$ & & & \\
\hline $\mathrm{CO}$ & Fast response resonance fluorescence, & $1 \mathrm{~s}$ & $1.5 \mathrm{ppbv}$ & $2 \%( \pm 1 \sigma)$ & Purvis et al. (2005) \\
\hline $\mathrm{O}_{3}$ & UV photometric analyser, & $1 \mathrm{~s}$ & $0.6 \mathrm{ppbv}$ & $(\text { DEFRA) })^{\mathrm{c}} 2 \%( \pm 1 \sigma)$ & Heard et al. (2006) \\
\hline $\mathrm{C}_{2}-\mathrm{C}_{7} \mathrm{NMHC}$ and DMS & WAS sampling with subsequent GC-FID & - & $0.5-6 \mathrm{pptv}$ & $<10 \mathrm{pptv}$ & \\
\hline
\end{tabular}

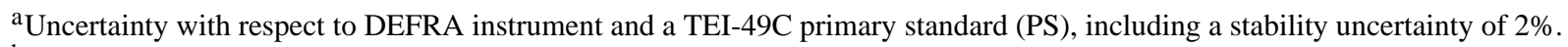

${ }^{\mathrm{b}}$ Uncertainty with respect to DEFRA instrument and a TEI-49C primary standard (PS), including a stability uncertainty of $2 \%$.

${ }^{\mathrm{c}}$ Uncertainty with respect to TEI-49C primary standard (PS) and including a stability uncertainty of $2 \%$.

A gas and aerosol phase model of halogen chemistry is described in Saiz-Lopez et al. (2006a, b), and used to calculate the gas phase concentration of a number of halogen intermediates for comparison with field measurements. The model considers the impact of coastal emissions of molecular iodine on $\mathrm{O}_{3}$ concentrations, and calculates the rate of nucleation of iodine oxide nanoparticles and their subsequent growth by condensation and coagulation.

\section{Measurements of atmospheric composition}

Figure 1 (panel b) shows the sampling positions of the measured species. The sampling inlet for the measurement of VOCs, aerosol, and reactive halocarbons was at the top of the $23 \mathrm{~m}$ tower (panel b, Fig. 1). The Department of the En- vironment, Food and Rural Affairs (DEFRA) measurements of $\mathrm{O}_{3}$, and AGAGE measurements of $\mathrm{CO}, \mathrm{CH}_{4}$ and $\mathrm{H}_{2}$, were collected from the top of the $10 \mathrm{~m}$ tower along with the $\mathrm{CN}$ and meteorological data. Both towers were within $100 \mathrm{~m}$ of the ocean at high tide (Fig. 1). Measurements of short-lived free radicals were all made at the shoreline site via, custommade inlets localised at respective containers (see Fig. 1). The inlet for the Leeds peroxide instrument was also at the top of the $10 \mathrm{~m}$ tower. Some measurements, $\mathrm{HCHO}$ (Leeds), alkyl nitrates (UEA) and large-chain $\left(>\mathrm{C}_{7}\right)$ VOCs (York), were made in a third laboratory (Building C) situated $200 \mathrm{~m}$ east of the other measurements.

The Differential Optical Absorption Spectrometer (DOAS) instrument was housed in Building A and an $8.4 \mathrm{~km}$ path length was achieved by positioning a retro-reflector 


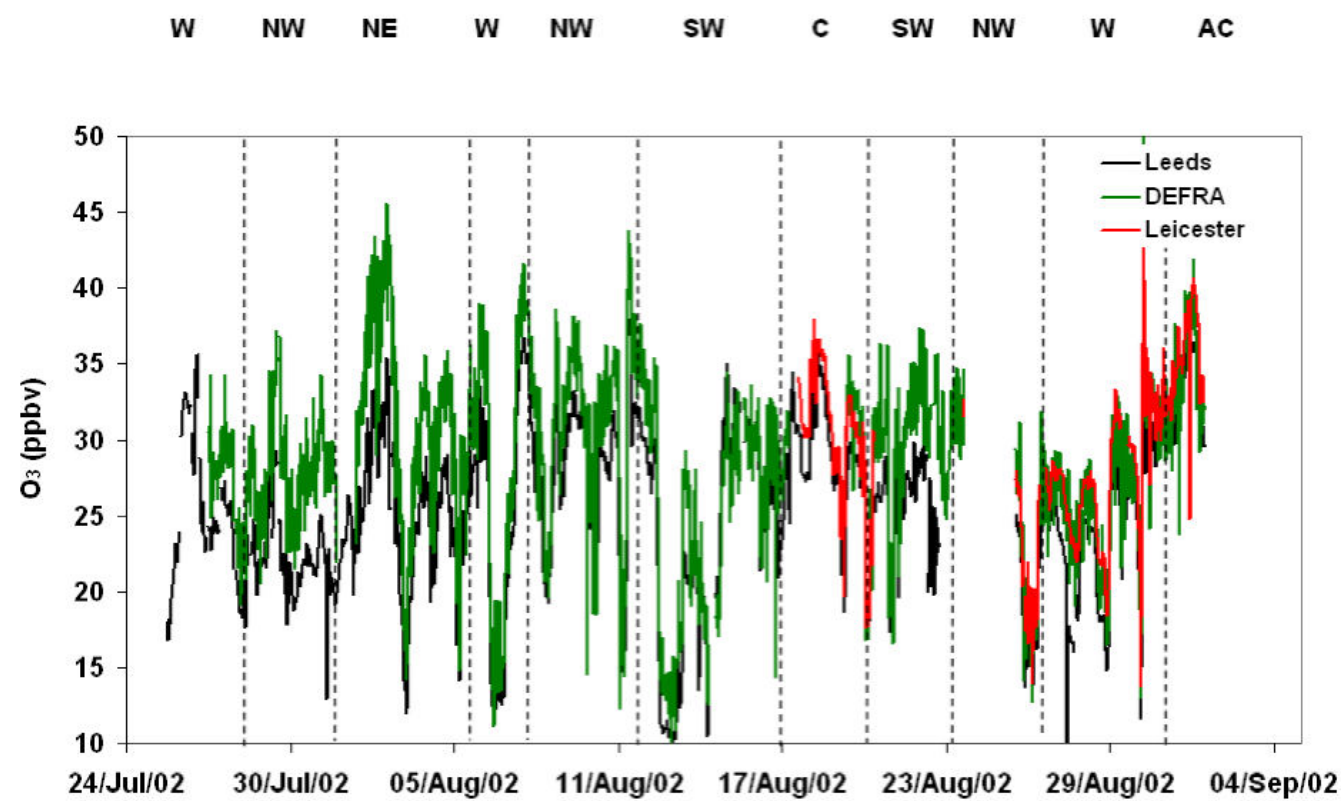

Fig. 4. Time-series of 30-min averaged $\mathrm{O}_{3} . \mathrm{W}=$ West, $\mathrm{NW}=$ Northwest, $\mathrm{NE}=$ Northeast, $\mathrm{SW}=$ Southwest, $\mathrm{C}=\mathrm{Cyclonic}, \mathrm{AC}=\mathrm{Anticyclonic}$.

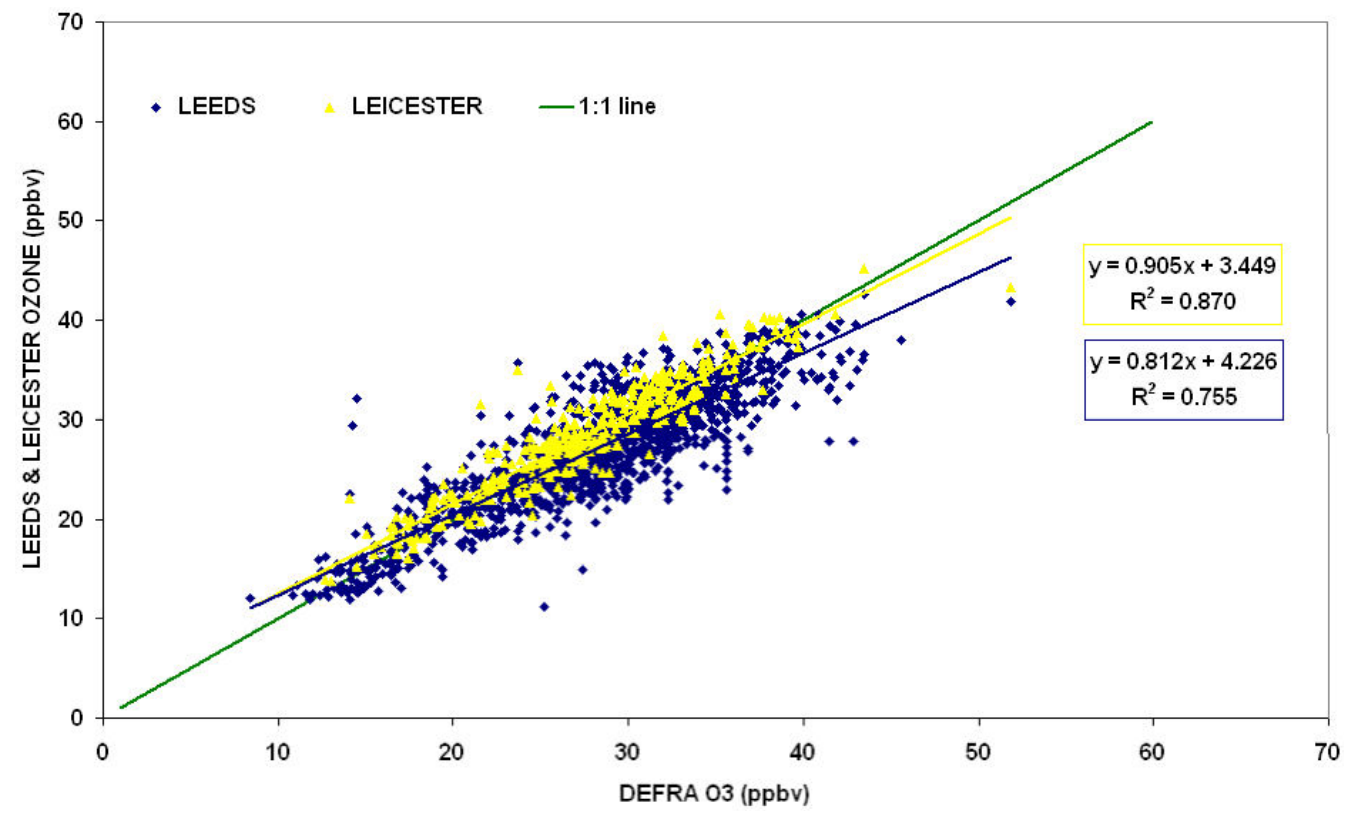

Fig. 5. Correlation of all $\mathrm{O}_{3}$ measurements made during NAMBLEX at Mace Head.

on Croaghnakeela Island, $4.2 \mathrm{~km}$ west of the site (panel a, Fig. 1). The light path ran mostly over the ocean, at a height of between 4 and $10 \mathrm{~m}$ (Saiz-Lopez et al., 2006a, b). The Broad Band Cavity Ringdown Spectrometer (BBCRDS) sampled via a similar $(10 \mathrm{~km})$ effective absorption path length, but was achieved with a spatial resolution of $2 \mathrm{~m}$ via an open-path ringdown cavity positioned $90 \mathrm{~cm}$ above the
Cambridge container (Bitter et al., 2005, 2006 ${ }^{1}$ ).

\footnotetext{
${ }^{1}$ Bitter, M., Ball, S. M., Povey, I. M., Jones, R. L., Saiz-Lopez, A., and Plane, J. M. C.: Measurements of $\mathrm{NO}_{3}, \mathrm{~N}_{2} \mathrm{O}_{5}$, OIO, $\mathrm{I}_{2}$, water vapour and aerosol optical depth by broadband cavity ring down spectroscopy during the NAMBLEX campaign, Atmos. Chem. Phys. Discuss., to be submitted , 2006.
} 
$3.1 \mathrm{O}_{3}$

As $\mathrm{O}_{3}$ is such a central tropospheric species, three independent measurements were made during NAMBLEX and these are shown in Fig. 4. Details of the three instruments are: (1) Department of Environment, Food and Rural Affairs (DEFRA) Monitor Labs UV spectrometer (permanently installed at Mace Head), which uses UV absorption at $254 \mathrm{~nm}$ to make measurements at a height of $3 \mathrm{~m}$ above the ground from the $23 \mathrm{~m}$ main tower, reporting ozone every $10 \mathrm{~s}$ as $1 \mathrm{~min}$ averages for the entire campaign. (2) The University of Leeds TEI (Thermo Environmental Instruments Inc) 42C UV absorption instrument located at a height of $5 \mathrm{~m}$ from the ground reported 1 minute averages for the entire campaign, and (3) The University of Leicester TEI 42C UV absorption instrument operated from building B (Fig. 1), sampling from a height of $4 \mathrm{~m}$ above the ground. This latter instrument was primarily deployed on the NERC Dornier 228-101 research aircraft (Purvis et al., 2005), with measurements only made at the Mace Head site at the end of the campaign (17-20 August, 26 August -4 September).

Figure 5 shows correlation plots with respect to the DEFRA measured $\mathrm{O}_{3}$ for the entire campaign from which the following best-fit linear regressions were found:

$$
\begin{aligned}
& \operatorname{Leic}\left(\mathrm{O}_{3}\right)=\left[0.905 \times \operatorname{DEFRA}\left(\mathrm{O}_{3}\right)\right]+3.4 \mathrm{ppbv} R^{2}=0.87 \\
& \operatorname{Leeds}\left(\mathrm{O}_{3}\right)=\left[0.812 \times \operatorname{DEFRA}\left(\mathrm{O}_{3}\right)\right]+2.5 \mathrm{ppbv} R^{2}=0.75
\end{aligned}
$$

During 17-20 August and 26 August-4 September when all three instruments were measuring simultaneously, the best-fit linear regressions were:

$$
\begin{aligned}
& \operatorname{Leic}\left(\mathrm{O}_{3}\right)=\left[0.905 \times \operatorname{DEFRA}\left(\mathrm{O}_{3}\right)\right]+3.5 \mathrm{ppbv} R^{2}=0.87 \\
& \operatorname{Leeds}\left(\mathrm{O}_{3}\right)=\left[0.903 \times \operatorname{DEFRA}\left(\mathrm{O}_{3}\right)\right]+0.6 \mathrm{ppbv} R^{2}=0.82
\end{aligned}
$$

During NAMBLEX all three instruments were independently calibrated on site by the National Physics Laboratory (NPL) using a certified standard. This process corrects the absorbance reading for the temperature and pressure measurement drifts within the respective instruments. All three instruments were within $10 \%$ of this calibration standard and the calibration was applied to the entire dataset. In addition a $\mathrm{GAW} \mathrm{O}_{3}$ audit was carried out by EMPA Swiss Federal Laboratories for Materials Testing and Research during the campaign (21-26 August) and all three instruments were checked against a TEI-49C PS (Primary Standard). While both Leicester and Leeds instruments were within GAW specifications, they actually were not as well calibrated as they could have been - the factory settings for background and slope were a little different. The Leicester instrument was calibrated and the settings were adjusted to give more or less perfect agreement with the Primary Standard (PS). Although the Leeds instrument was not adjusted, the calibration was applied to the final data.

$\mathrm{PS}=[\mathrm{DEFRA} \times 1.011]-0.39 \mathrm{ppbv}$
$\mathrm{PS}=[$ Leicester $\times 1.065]-0.93 \mathrm{ppbv}($ before calibration $)$

$\mathrm{PS}=[$ Leicester $\times 0.999]-0.01 \mathrm{ppbv}($ after calibration $)$

$\mathrm{PS}=[$ Leeds $\times 1.027]+1.68 \mathrm{ppbv}$

Laboratory tests have shown the stability of the ozone instruments to be $<2 \%$ at all levels and this has been included into the uncertainties detailed in Table 1. However, even considering these uncertainties, after calibrations the three instruments report values which differ by up to $20 \%$. Investigations into this are on-going and so in the meantime the reason for the discrepancy remains unknown.

The Leeds measurements were used to constrain the models for the calculation of free-radical concentrations (Sommariva et al., 2005a, b) as the instrument inlet was positioned closest to where the $\mathrm{HO}_{x}$ measurements were made. Errors resulting from ozone measurement uncertainty were taken into account in the final modelled free-radical concentrations. The DEFRA data series, which was considerably noisier, was used for the interpretation of sampled air masses and correlations with longer lived species. The Leicester instrument was used on the aircraft for a significant part of the campaign (Purvis et al., 2005) and so the time-series is more limited.

The maximum and minimum 1-min averaged $\mathrm{O}_{3}$ mixing ratio using the DEFRA instrument was $53.4 \mathrm{ppbv}$ and $6.3 \mathrm{ppbv}$ respectively, with a campaign average of $29.0 \pm 6.5 \mathrm{ppbv}$, within error of previous average summer $\mathrm{O}_{3}$ measurements at Mace Head between 1988 and 2002 (Simmonds et al, 2004; Monks, 2005; Simmonds et al., 1997).

\section{$3.2 \mathrm{CO}$ and $\mathrm{H}_{2}$}

$\mathrm{CO}$ and $\mathrm{H}_{2}$ were measured by AGAGE (http://agage.eas. gatech.edu/) using a RGA3 (Residual Gas analyzer) hot mercuric oxide reduction gas detector coupled with UV detection. Alternate calibration and ambient air measurements were recorded every $40 \mathrm{~min}$ during the campaign except for a period between the 1 and 2 August and between the 17 and 21 August because of technical difficulties. For modelling purposes missing $\mathrm{CO}$ data at these times were inferred from the correlation with acetylene (Smith et al., 2006):

$$
[\mathrm{CO}]=270\left[\mathrm{C}_{2} \mathrm{H}_{2}\right]+68.88 \mathrm{ppbv}, R_{\text {whole campaign }}^{2}=0.84
$$

An average of $91.3 \pm 18.9 \mathrm{ppbv}$ was observed for CO through the campaign with a minimum of $58 \mathrm{ppbv}$ and maximum of 197 ppbv. A time-series for CO is shown on Fig. 6 along with acetylene and DMS.

The time-series for $\mathrm{H}_{2}$, a relatively minor contributor to the reactive loss of $\mathrm{OH}(\sim 6 \%)$ is shown in Fig. 7. The campaign average of $503.4 \pm 24.9 \mathrm{ppbv}$ is slightly lower than the globally averaged value of $531 \mathrm{ppbv}$, but is consistent with the minimum at Mace Head occurring during August/September (Novelli et al., 1999). The concentration of 


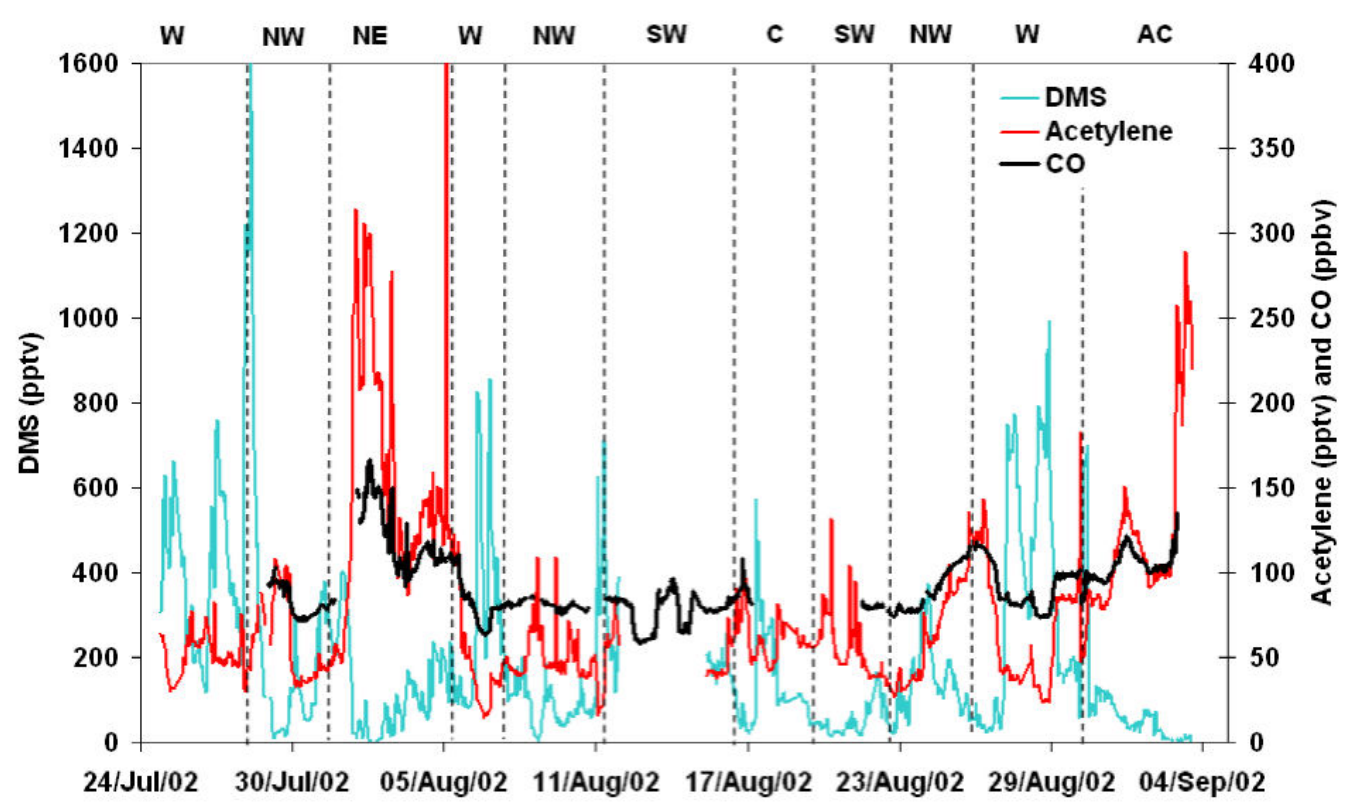

Fig. 6. Time-series of carbon monoxide, acetylene and dimethyl sulfide.

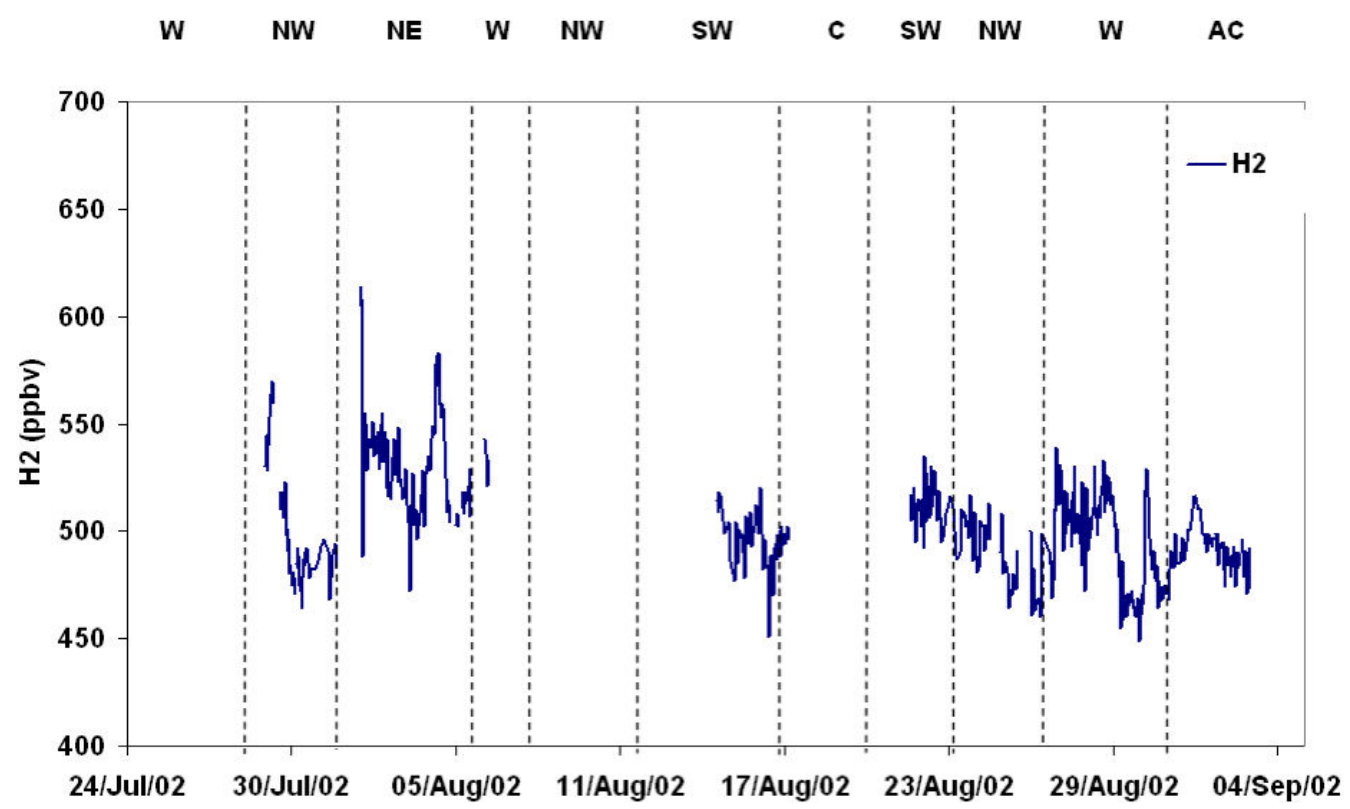

Fig. 7. Time-series for hydrogen at Mace Head during NAMBLEX.

$\mathrm{H}_{2}$ is lower in the northern hemisphere when compared to the southern hemisphere except at very high latitudes, because in addition to reaction with $\mathrm{OH}$ the other main sink for this species is uptake by soils which is larger in the northern hemisphere (Simmonds et al., 2000).

\section{$3.3 \mathrm{CH}_{4}$}

Atmospheric $\mathrm{CH}_{4}$ concentrations were determined by AGAGE every $40 \mathrm{~min}$ using a Gas Chromatograph-Flame
Ionisation Detector (GC-FID) and are shown in Fig. 8, together with propane and $\mathrm{CO}$. Although the lifetime for $\mathrm{CH}_{4}$ is long ( $\sim 9$ years), correlations with NMHC for example propane, $\left(\mathrm{C}_{3} \mathrm{H}_{8}\right)$, and also $\mathrm{CO}$, are commonly seen (Methven et al., 2001), and can be explained by changes in air mass origin, sources and photochemical history. For NAMBLEX, the following best-fit linear fits were obtained:

$$
\left[\mathrm{CH}_{4}\right]=850\left[\mathrm{C}_{3} \mathrm{H}_{8}\right]+1754 \mathrm{ppbv} R_{\text {whole campaign }}^{2}=0.58
$$




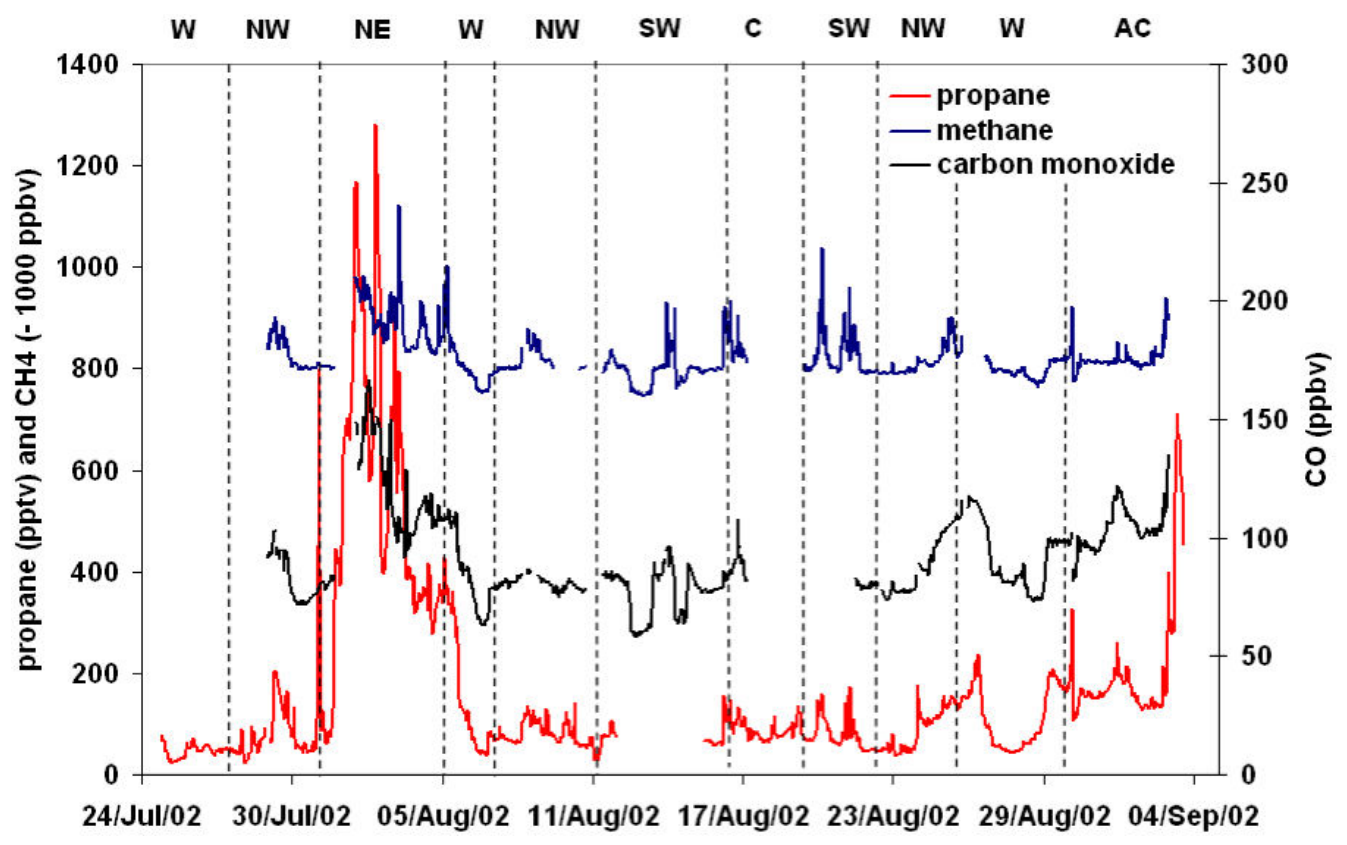

Fig. 8. Time-series of methane, propane and carbon monoxide.

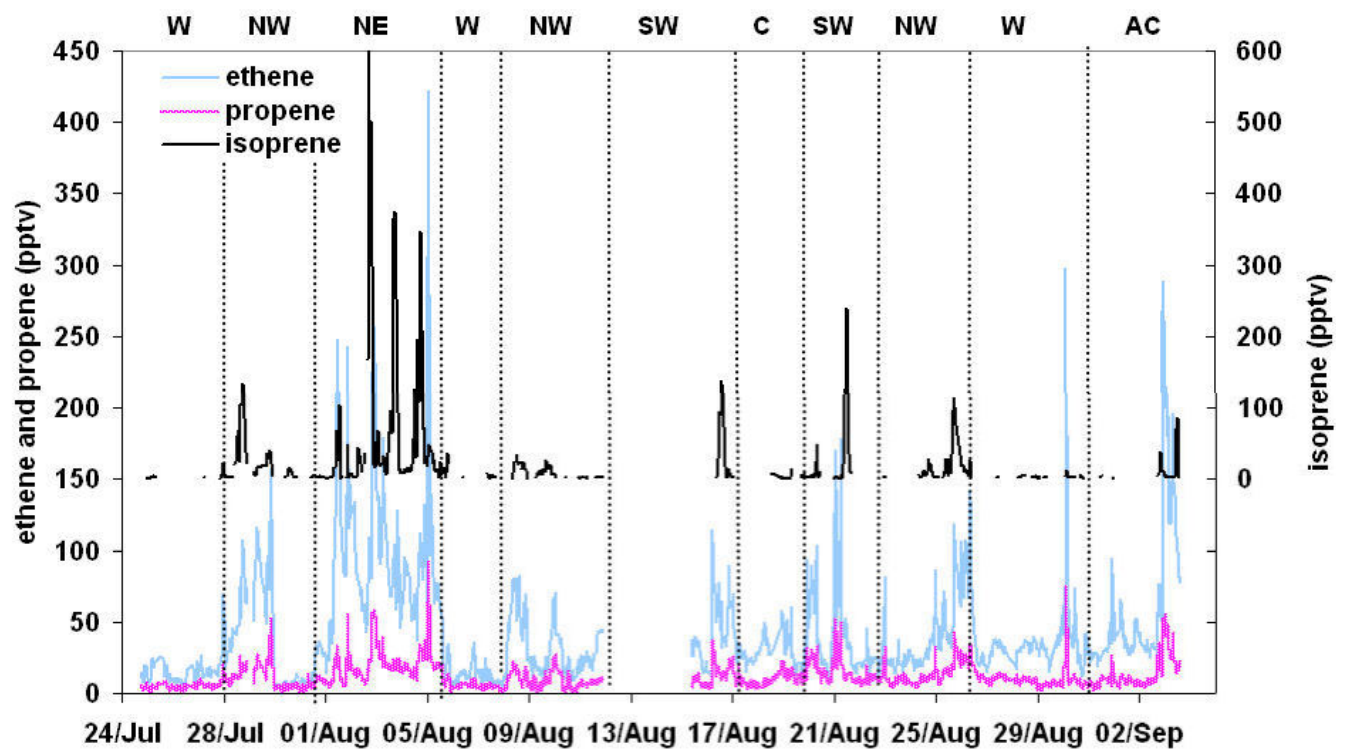

Fig. 9. Time-series of ethene, propene, and isoprene (vertically displaced for clarity).

$[\mathrm{CO}]=0.33\left[\mathrm{CH}_{4}\right]-517.8 \mathrm{ppbv} R_{\text {whole campaign }}^{2}=0.61$

$\mathrm{CH}_{4}$ is an important sink for $\mathrm{OH}$, and when $\mathrm{CH}_{4}$ measurements were not available, concentrations were inferred from the correlation with propane (Smith et al., 2006).
3.4 Non-methane hydrocarbons (NMHCs) and oxygenated volatile organic compounds (o-VOCs)

A total of $23 \mathrm{C}_{2}-\mathrm{C}_{7} \mathrm{NMHC}$ (including dimethyl sulphide (DMS)) and three o-VOCs, (methanol, acetone and acetaldehyde), were measured simultaneously with $40 \mathrm{~min}$ resolution during the campaign using a newly developed automated dual channel Perkin Elmer GC-FID coupled to a thermal desorption sampling system. More details are given in Hopkins et al. (2002). Formaldehyde (HCHO) measurements 
are discussed in the next section. Figures 6,8 and 9 show time-series for some NMHC species during NAMBLEX, with excellent data coverage except for 13-16 August (failed pump). The larger NMHC and $>\mathrm{C}_{3}$ oxygenates were also measured using an Agilent $6890 \mathrm{GC}$ with two independent columns connected via a valve modulator device (Hamilton and Lewis., 2003). The NMHC data were used in conjunction with observed $\mathrm{CH}_{4}, \mathrm{CO}, \mathrm{NO}_{\mathrm{x}}, \mathrm{NO}_{\mathrm{y}}$ and $\mathrm{O}_{3}$ data to produce a chemical climatology for the duration of the campaign, which is discussed in Sect. 6. Possible sources of NMHC include direct anthropogenic and biogenic emission, whereas for the o-VOCs another source is oxidation of precursor NMHC along the sampled trajectory. For oVOCs, possible sinks include reaction with $\mathrm{OH}$, deposition to the ocean, and photolysis, and these points are discussed in Lewis et al. (2005). Methanol deposition to the ocean and DMS flux from the ocean during NAMBLEX have been discussed in detail in Carpenter et al. (2004).

\subsection{Formaldehyde (HCHO)}

$\mathrm{HCHO}$ was measured using two independent techniques during NAMBLEX and although the sampling position of the instruments were $200 \mathrm{~m}$ apart, the campaign offered an opportunity for intercomparison. The University of Leeds deployed a Gas Chromatograph with pulsed discharge Helium Ionisation Detection (GC-pd-HID), with selective cryogenic trapping, which was situated in the laboratory at the top site ( $300 \mathrm{~m}$ from the ocean at high tide, $25 \mathrm{~m}$ a.s.l.), whilst UEA used the Hantzsch method, utilising a glass coil scrubber with derivitisation of $\mathrm{HCHO}$ and UV fluorescence detection, with the instrument deployed at the shoreline site in container 5 (panel b, Fig. 1). The time-series for the two methods, together with a model comparison, are discussed in Still et al. (2005). The temporal variation of the two sets of measurements correlated closely, but an offset was observed between them $\left(\mathrm{y}=1.11( \pm 0.06) \times+0.65( \pm 0.02) \mathrm{R}^{2}=0.52\right)$.

\subsection{Inorganic $\left(\mathrm{H}_{2} \mathrm{O}_{2}\right)$ and organic $\left(\mathrm{CH}_{3} \mathrm{OOH}\right)$ peroxides}

Speciated peroxide measurements were also measured by two instruments positioned in close proximity at the shoreline site (panel b, Fig. 1). UEA (Container 5) used scrubbing of peroxides into solution followed by the catalysed reduction of peroxides by para hydroxyl phenyl acetic acid (POPHA), followed by fluorescence detection of the products formed. Reaction with the enzyme catalase, which selectively removes $\mathrm{H}_{2} \mathrm{O}_{2}$ prior to measurement, enables speciated measurements of total peroxide and $\mathrm{H}_{2} \mathrm{O}_{2}$. The University of Leeds (Building A) deployed an instrument which scrubbed peroxide into solution using a nebulisation reflux concentrator, followed by separation by High Performance Liquid Chromatography (HPLC) and postcolumn enzyme derivatisation with fluorescence detection (Morgan and Jack- son, 2002). The measurements from NAMBLEX are discussed in Jackson et al. (2006) ${ }^{2}$.

\subsection{Reactive halogen species (RHS)}

Reactive organo-halogens including $\mathrm{CH}_{3} \mathrm{I}$ (methyl iodide), $\quad \mathrm{C}_{2} \mathrm{H}_{5} \mathrm{I}$ (ethyl iodide), $\mathrm{CH}_{2} \mathrm{IC}_{2} \mathrm{H}_{5}$, (1iodopropane) and $\mathrm{CH}_{3} \mathrm{CHICH}_{3}$ (2-iodopropane), $\mathrm{CH}_{2} \mathrm{ICl}$ (chloroiodomethane), $\mathrm{CH}_{2} \mathrm{I}_{2}$ (diodomethane), $\mathrm{CH}_{2} \mathrm{Br}_{2}$ (dibromomethane), $\mathrm{CHBr}_{2} \mathrm{Cl}$ (dibromochloromethane), $\mathrm{CHBr}_{3}$ (bromoform), and $\mathrm{CHCl}_{3}$ (chloroform) were measured by a GC-MS (Gas-Chromatography-Mass Spectrometry) system operated by the University of York (Container 2) (Wevill and Carpenter, 2004). $\mathrm{CHBr}_{3}$ measurements made by the University of York during NAMBLEX and during a 2.5 year period by a GC-MS system operated by the University of Bristol (Building B) are discussed in Carpenter et al. (2005), with evidence of a terrestrial source. In addition, both instruments measured $\mathrm{CHCl}_{3}$ and the good agreement between the concentrations is also discussed.

$\mathrm{I}_{2}$, OIO, IO, and $\mathrm{BrO}$ were detected using the UEA DOAS instrument from spectra in the regions $535-575 \mathrm{~nm}, 535-$ $575 \mathrm{~nm}, 430-460 \mathrm{~nm}$, and $345-359 \mathrm{~nm}$, respectively, with a time resolution of $30 \mathrm{~min}$. These represent the first measurements of $I_{2}$ in the atmosphere, a compound which itself may be the major source of atmospheric iodine in many coastal regions rich in macro-algae. First estimations of its contribution to the global iodine budget are considered in SaizLopez and Plane (2004) who show that this species may well be a significant component. NAMBLEX was also the first time $\mathrm{BrO}$ had been measured in mid-latitude regions. The presence of $\mathrm{I}_{2}$, IO and OIO in measurable concentrations during the night was of particular interest, as previously discussed for NAMBLEX in Saiz-Lopez and Plane (2004) and Saiz-Lopez et al. (2004). A mechanism for the gas and aerosol-phase chemistry of iodine, including the nucleation of particles, was developed and is discussed in Saiz-Lopez et al. (2006a) and McFiggans et al. (2004).

The Broadband cavity ringdown spectrometer (BBCRDS), developed by Cambridge University (Container 6, Fig. 1b), was deployed for the first time during NAMBLEX, and is discussed in Bitter et al. (2005). The technique uses a Nd:YAG pumped modeless dye laser with broad spectral output which enters a high-finesse cavity containing highly reflecting mirrors. Measurements of OIO and $\mathrm{I}_{2}$ were performed with a spatial resolution of $2 \mathrm{~m}$ by recording wavelength resolved ringdown times around $570 \mathrm{~nm}$ using a clocked charge coupled device (CCD) camera. Exchanging the cavity mirrors and laser dye enabled measurements of the $\mathrm{NO}_{3}$ radical and its reservoir compound $\mathrm{N}_{2} \mathrm{O}_{5}$ to be performed around $660 \mathrm{~nm}$. Aerosol optical depths and wa-

\footnotetext{
${ }^{2}$ Jackson, A., Morgan, R. B., Mills, G., et al.: Gas phase hydroperoxide measurements at Mace Head, Ireland, during the NAMBLEX campaign, in preparation, 2006.
} 
ter vapour concentrations were also measured in both wavelength regions (Bitter et al., 2006 ${ }^{1}$ ).

\section{$3.8 \mathrm{NO}_{3}$}

$\mathrm{NO}_{3}$ was measured during the campaign using both the DOAS technique (with the telescope and receiving optics situated in Building A (Fig. 1) and the long-path almost entirely over the ocean) and the in situ BBCRDS technique, situated in Container 6 (Fig. 1), sampling on land but close to the shore. The two time-series for $\mathrm{NO}_{3}$ provided a unique opportunity to examine horizontal gradients in the radical's concentration in air advected across the land/ocean interface, as discussed in Bitter et al. (2006) ${ }^{1}$. In addition a verticallypointing Zenith sky spectrometer was deployed to measure the slant column density (SCD) variation of $\mathrm{NO}_{3}$ as a function of the solar zenith angle (SZA) during sunrise, from which vertically resolved $\mathrm{NO}_{3}$ concentrations in the MBL and free troposphere were determined. The $\mathrm{NO}_{3}$ time-series from the DOAS and Zenith sky spectrometers, and a discussion of night-time chemistry, are presented in Saiz-Lopez et al. (2006b).

\section{9 $\mathrm{NO}, \mathrm{NO}_{2}$, total $\mathrm{NO}_{\mathrm{y}}$, PAN, alkyl nitrates, and $\mathrm{HNO}_{3}$}

Measurements of nitric oxide (NO), nitrogen dioxide $\left(\mathrm{NO}_{2}\right)$, total $\mathrm{NO}_{\mathrm{y}}$ and total $\mathrm{NO}_{\mathrm{y}}$ minus nitric acid $\left(\mathrm{HNO}_{3}\right)$ were made by a 4-channel analyser which detected the chemiluminescence produced upon reaction of $\mathrm{NO}$ with $\mathrm{O}_{3}$. Before detection, $\mathrm{NO}_{2}$ was first converted to $\mathrm{NO}$ using a photolysis converter consisting of a Peltier cooled quartz cylindrical cell (Bauguitte, 2000) which gave a stable conversion efficiency of around $35 \%$. The stability of this system relies on the lamp which has a 500 hour lifetime and when degraded is replaced. $\mathrm{NO}_{\mathrm{y}}$ measurements were made with a gold converter which reduced all $\mathrm{NO}_{\mathrm{y}}$ species including PAN, $\mathrm{NO}_{2}$, $\mathrm{HNO}_{3}$, and organic nitrates to $\mathrm{NO}$ before detection. The converter was run at $300^{\circ} \mathrm{C}$ in the presence of carbon monoxide (CO). Nitric acid was determined by subtracting the signal from two identically specified $\mathrm{NO}_{\mathrm{y}}$ converters, the only difference being that one had a length of nylon tube between the inlet and the converter to remove the $\mathrm{HNO}_{3}$ before detection. The converters had previously been validated in the laboratory with both instruments in the same set-up. In addition nitric acid permeation tubes were used to check the agreement between the conversion efficiency of $\mathrm{HNO}_{3}$ on the converters and to ensure that the nylon denuder removes all the $\mathrm{HNO}_{3}$ before the sample air stream reaches the hot gold surface. Direct measurements of the nylon tube efficiency were not done although thought to be greater than 95\%. Comparative experiments with $\mathrm{HNO}_{3}$ filter pack measurements showed excellent agreement (Gradient 1.03, $\mathrm{R}^{2}=0.99$ ) indicating a very high efficiency for this removal. Full details of the instrument with detection limits and uncertainties are quoted in Brough et al. (2003) and are reproduced in Table 1.

Peroxy acetyl nitrate (PAN) was measured by a standard GC-ECD (Gas Chromatography-Electron Capture Detection) method. A $2 \mathrm{ml}$ sample of air, dried with a Nafion ${ }^{\mathrm{TM}}$ dryer, was injected onto a $10 \mathrm{~m}$ length and $0.53 \mathrm{~mm}$ diameter, MXT-200 column (Thames Restek Ltd) and separation was isothermal at $15^{\circ} \mathrm{C}$ with nitrogen as the carrier gas. Detection was by ECD and the duty cycle of the instrument was $10 \mathrm{~min}$. Calibrations (using the acetone/air/NO photolysis method) were usually performed twice a day at single PAN concentrations and blanks were performed every few days by inserting a length of stainless steel tube into the inlet line and heating to $120^{\circ} \mathrm{C}$. Full calibration curves were performed at the start and end of the campaign. A detection limit of $15 \mathrm{pptv}(\mathrm{s} / \mathrm{N}=3)$ was achieved with an estimated total uncertainty (based on NO standard, NO conversion efficiency, gas flows and instrument precision) of $\pm 16 \%$.

At the beginning of the campaign the measurement of $\mathrm{NO}_{\mathrm{x}}$ and $\mathrm{NO}_{\mathrm{y}}$ species were unfortunately compromised by local contamination problems. This gave rise to large excursions in the signals of $\mathrm{NO}, \mathrm{NO}_{2}$ and $\mathrm{NO}_{\mathrm{y}}$. The $\mathrm{NO}_{x}$ and $\mathrm{NO}_{y}$ datasets were flagged prior to submission and the contaminated data was removed prior to plotting, analysis, or averaging. The origin of the spikes is unknown (e.g. electronic or contamination), and they were classified using local wind direction, wind speed and CPC counts. Some were not correlated at all with particle count from the CPC, suggesting it is not a sitewide meteorological feature. In addition these were large and of very short duration ( $<3$ data points), and hence extremely easy to identify and remove. Others which were not as intense and longer in duration (but still less than a minute or so), were correlated with CPC count, suggesting a site-wide meteorological event. However, they were quite obvious and as they were not representative of the general NO levels over that period were not included in the modelling, or for calculating average values for that period. Following the removal of flagged data, the remaining $\mathrm{NO}_{\mathrm{xy}}$ data should be of high quality and can be used without undue concern. Figure 10 shows a plot of $\mathrm{NO}, \mathrm{NO}_{2}$ and $\mathrm{NO}_{\mathrm{y}}$ expressed as hourly averages after removal of contamination.

The nitric oxides $\mathrm{NO}$ and $\mathrm{NO}_{2}\left(\mathrm{NO}_{\mathrm{x}}\right)$ are converted into more highly oxidised forms in the atmosphere such as $\mathrm{HNO}_{3}$, PAN and organic nitrates. The total amount of oxidised nitrogen present is referred to as $\mathrm{NO}_{\mathrm{y}}$ and $\mathrm{NO}_{\mathrm{z}}\left(\mathrm{NO}_{\mathrm{z}}=\mathrm{NO}_{\mathrm{y}}-\mathrm{NO}_{\mathrm{x}}\right)$. A good test of the performance of the $\mathrm{NO}_{\mathrm{y}}$ instrumentation is to compare the measured $\mathrm{NO}_{\mathrm{y}}$ signal with the sum of $\mathrm{NO}$, $\mathrm{NO}_{2}, \mathrm{HNO}_{3}$ and PAN, most of which are determined independently. This is shown in Fig. 11 where the two quantities $\left(\mathrm{NO}_{\mathrm{y}}\right.$ measured and $\mathrm{NO}_{\mathrm{y}}$ calculated) are shown to coincide throughout the campaign.

The sum of $\mathrm{HNO}_{3}$ and PAN also coincides with the $\mathrm{NO}_{z}$ signal calculated from $\mathrm{NO}_{\mathrm{y}}-\mathrm{NO}_{\mathrm{x}}$ throughout much of the campaign (not shown) suggesting that the total organic nitrate signal $\left(\Sigma \mathrm{RONO}_{2}\right)$ is small. Figure 12 shows a 


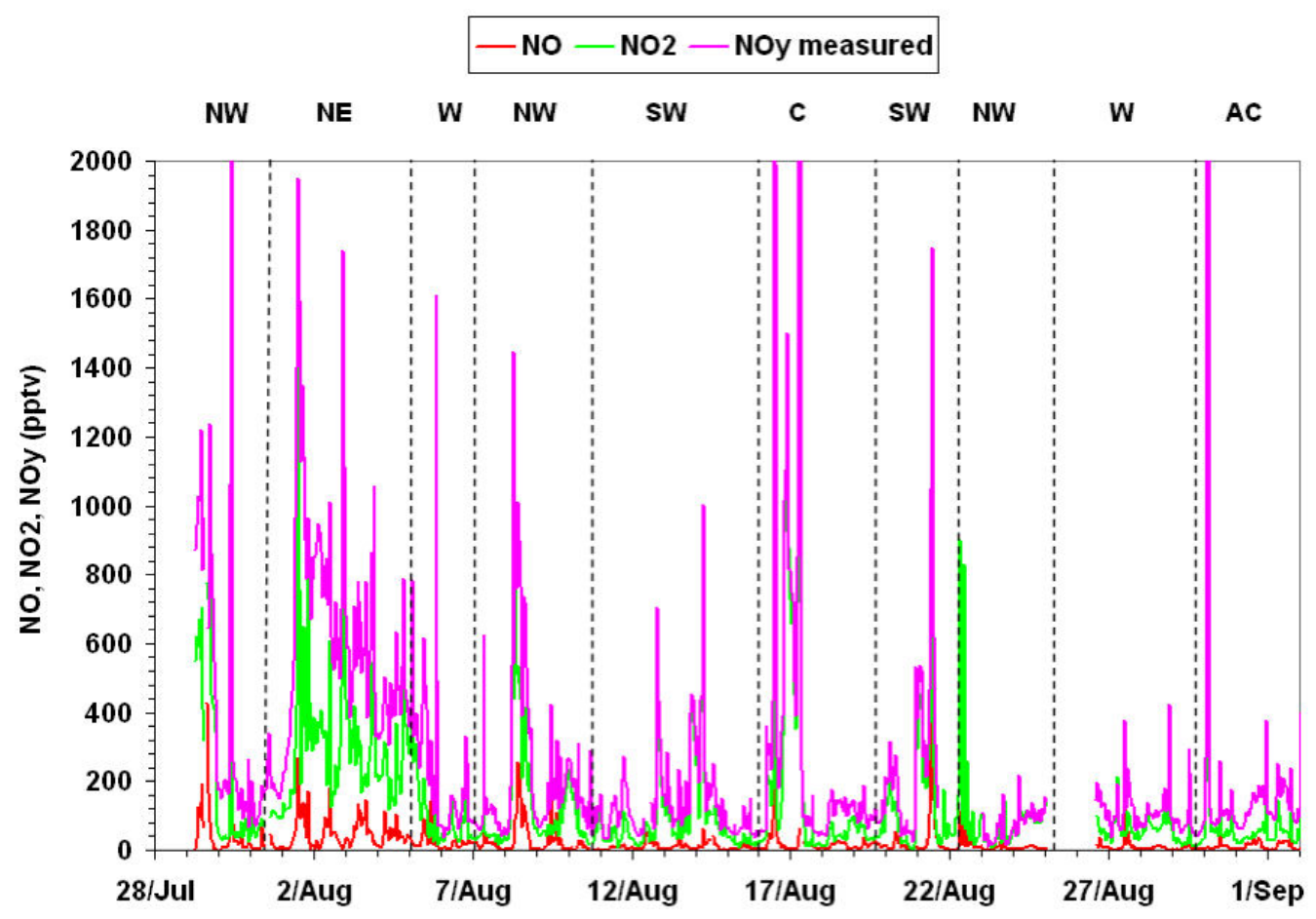

Fig. 10. Time-series of $\mathrm{NO}, \mathrm{NO}_{2}$, and measured $\mathrm{NO}_{\mathrm{y}}$.

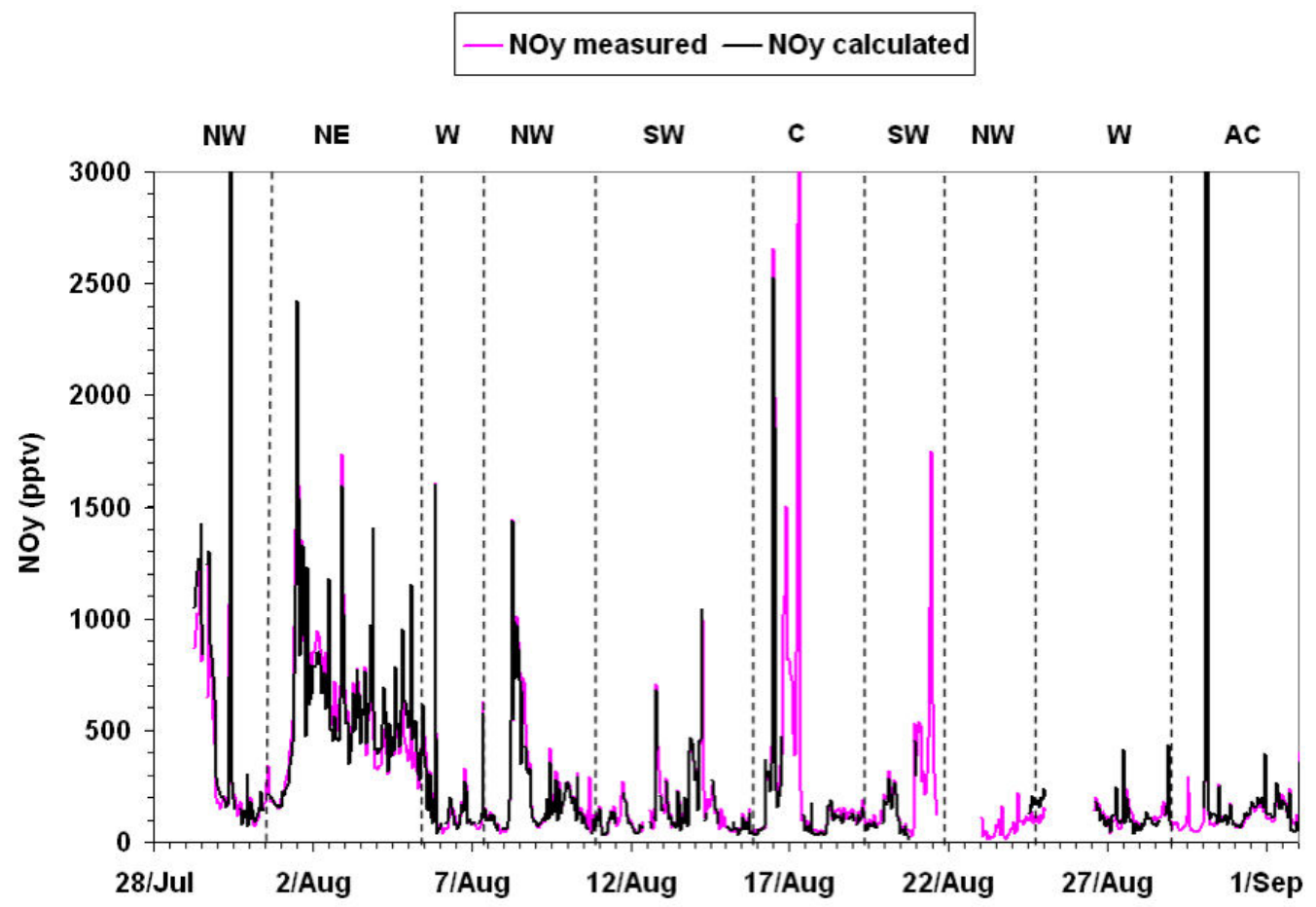

Fig. 11. Time-series of measured and calculated $\mathrm{NO}_{\mathrm{y}}$, the latter by summing the measured $\mathrm{NO}, \mathrm{NO}_{2}, \mathrm{HNO}_{3}, \mathrm{PAN}$ and organic $\mathrm{N}$.

plot of $\mathrm{NO}_{\mathrm{y}}, \mathrm{HNO}_{3}$ and PAN for the NAMBLEX campaign. The sum of the two products of atmospheric oxi- dation $\left(\mathrm{PAN}+\mathrm{HNO}_{3}\right)$ is approximately $50 \%$ of the $\mathrm{NO}_{y}$ on many occasions. In cleaner air however the two products can 


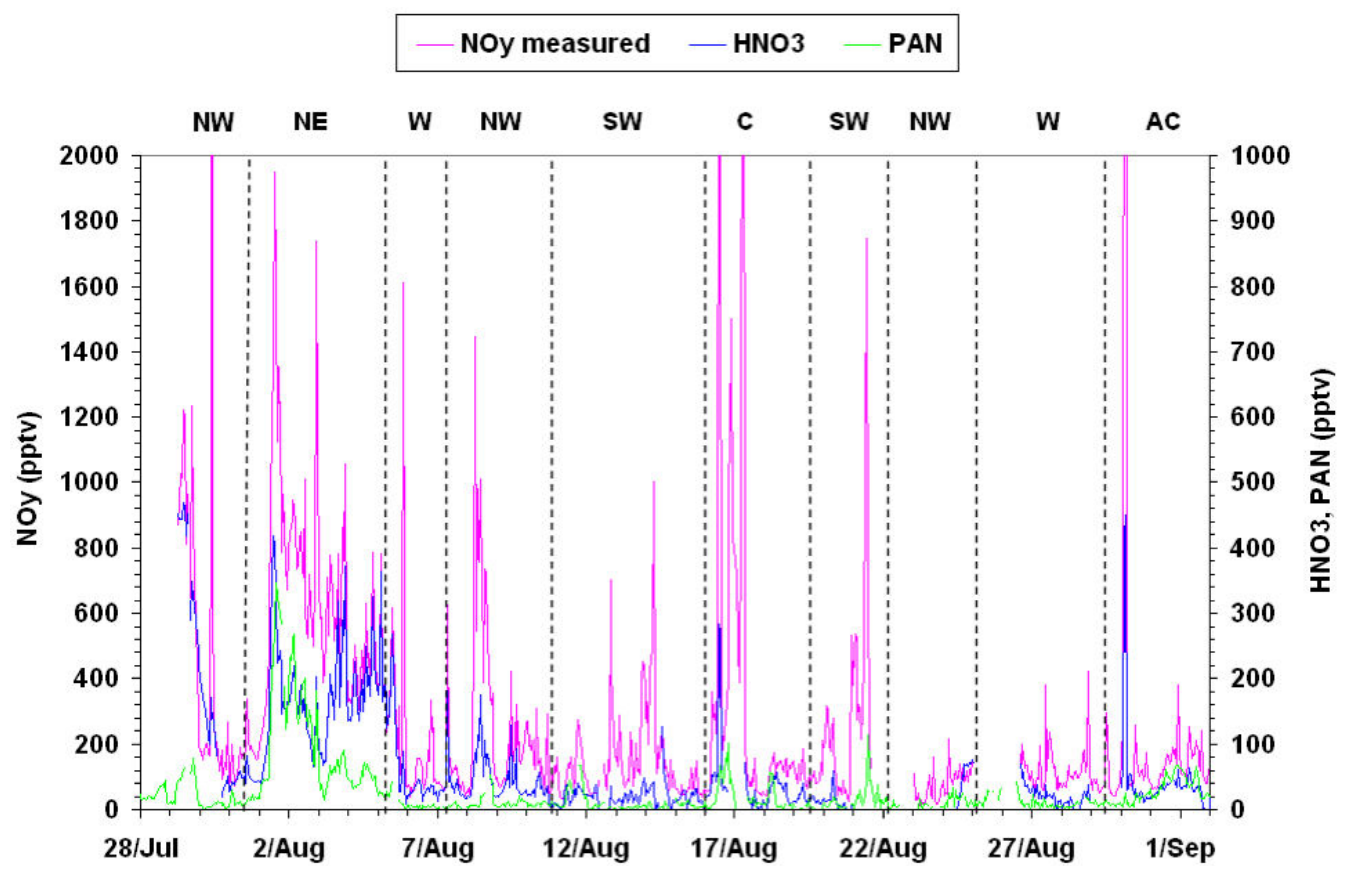

Fig. 12. Time-series of measured $\mathrm{NO}_{y}, \mathrm{HNO}_{3}$, and PAN.

dominate, as is shown towards the end of the campaign. The small amount of $\mathrm{NO}_{\mathrm{x}}$ present in clean air is very likely produced from decomposition of the PAN, or possibly a minor contribution from local soil emission; the $\mathrm{NO}_{\mathrm{x}}$ will then be quickly converted to $\mathrm{HNO}_{3}$ by reaction of $\mathrm{NO}_{2}$ with $\mathrm{OH}$, and $\mathrm{HNO}_{3}$ will be rapidly removed by dry deposition to any surface including the sea. Investigations into this process are on-going, but the combination of these data with other Mace Head datasets for these species will allow the budget of reactive nitrogen in marine boundary air, over the North Atlantic, to be assembled for all types of conditions experienced during this campaign.

\subsection{Photolysis rates}

Photolysis frequencies were measured using one $j-\left(\mathrm{NO}_{2}\right)$ fixed-bandwidth radiometer (FR) (above Container 5, Fig. 1b), two $j-\left(\mathrm{O}^{1} \mathrm{D}\right)$ fixed-bandwidth filter radiometers (above Containers 1 and 5, Fig. 1b), and a spectroradiometer (SR) (above Container 5, Fig. 1b) by the University of Leicester (Edwards and Monks, 2003) and the University of Leeds. All instruments used an upward pointing $2 \pi$ sr (sterradians) integrating spherical dome made of ground-quartz with an artificial horizon and all instruments had an integration time of $1 \mathrm{~min}$. The fixed-bandwidth radiometers measure solar radiation using a PMT after transmission through optical filters that mimic the wavelength-dependent product of the absorption cross-section $(\sigma)$ and photo-dissociation quantum yield $(\phi)$ of either $\mathrm{O}_{3}$ or $\mathrm{NO}_{2}$. Thus, the output signal of the filter radiometer is proportional to the spe- cific photolysis frequency and is calibrated by actinometry (see Monks et al., 2004). The spectroradiometer uses a single imaging spectrograph and a diode array detector to spectrally resolve sunlight in the range $285-710 \mathrm{~nm}$, and raw intensities are converted to actinic fluxes $(\mathrm{F})$ using primary irradiance standards (NIST) (see Hofzumahaus et al., 2004). Photolysis frequencies are then calculated using these fluxes and tabulated absorption cross-section and photodissociation quantum yield data, as described in Monks et al. (2004). Of particular interest during NAMBLEX are $j$ $\left(\mathrm{O}^{1} \mathrm{D}\right), j-\left(\mathrm{NO}_{2}\right), j-(\mathrm{HCHO}), j-\left(\mathrm{CH}_{3} \mathrm{CHO}\right), j-\left(\mathrm{CH}_{3} \mathrm{COCH}_{3}\right)$, $j$-(HONO), $j$ - $\left(\mathrm{H}_{2} \mathrm{O}_{2}\right), j-\left(\mathrm{CH}_{3} \mathrm{CO}_{2} \mathrm{H}\right), j-(\mathrm{HOI})$ and $j$-(HOBr).

Figures $13 \mathrm{a}$ and $\mathrm{b}$ show correlation plots of SR versus FR measured $j-\left(\mathrm{O}^{1} \mathrm{D}\right)$ and $j$ - $\left(\mathrm{NO}_{2}\right)$, respectively. For $j-\left(\mathrm{O}^{1} \mathrm{D}\right)$ the agreement is reasonable, with the observed scatter attributable to inadequacies in both the $j-\left(\mathrm{O}^{1} \mathrm{D}\right)$ FR and SR measurements. The slight curvature at low elevation sun, high solar zenith angles (SZAs), corresponding to low values of $j-\left(\mathrm{O}^{1} \mathrm{D}\right)$ highlights the shortcomings of filter radiometers at high SZAs, where the path length through the atmosphere is longer, and as a consequence, shifts the wavelength dependent spectral distribution of $j-\left(\mathrm{O}^{1} \mathrm{D}\right)\left(\sigma_{O 3}(\lambda) \times \phi_{O 1 D}(\lambda) \times F(\lambda)\right.$, see for example Monks et al., 2004) to longer wavelengths (Bohn et al., 2004; Hofzumahaus et al., 2004). In addition, the single spectrograph spectroradiometer used here inherently suffers from stray light effects (see Edwards and Monks, 2003, for details), which can have a significant effect on the measured actinic flux at short wavelengths (towards the $290 \mathrm{~nm}$ cut-off region) at all SZAs. A significant amount of scatter will be 

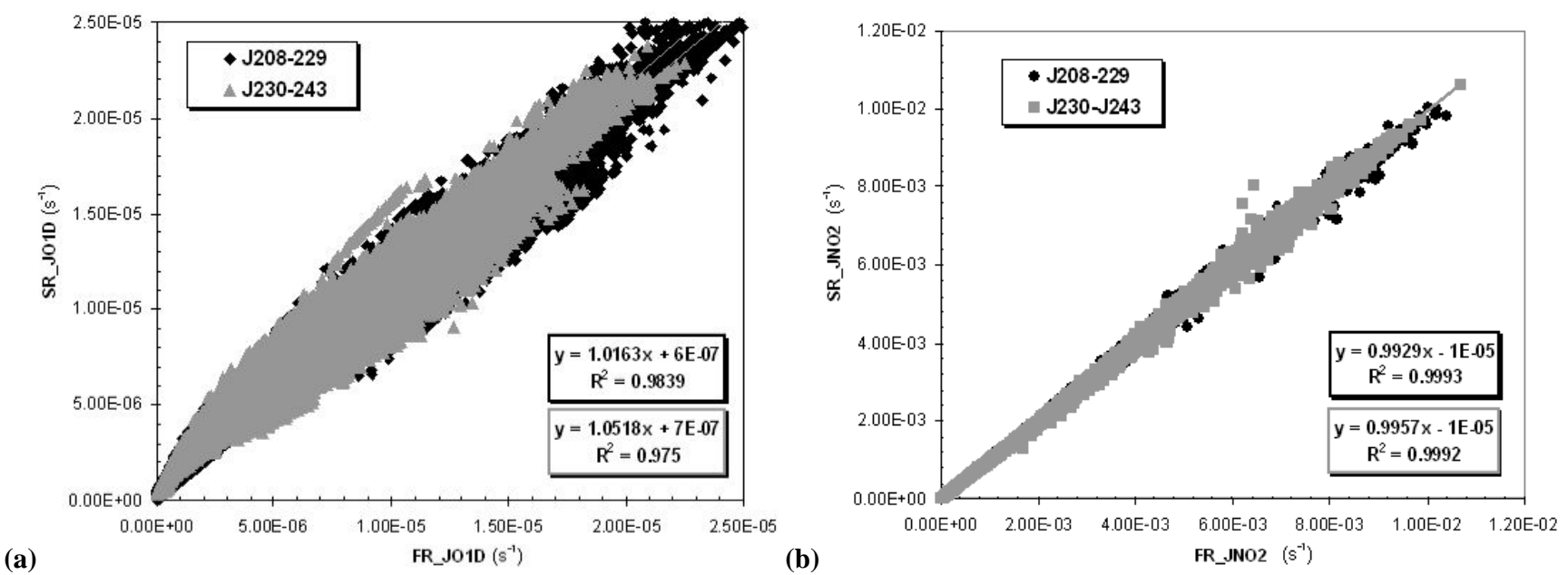

Fig. 13. (a): Correlation plot for $j-\left(\mathrm{O}^{1} \mathrm{D}\right)$ measured using the University of Leicester's filter radiometer (FR) and diode array spectroradiometer (SR). (b): Correlation plot for $j-\left(\mathrm{NO}_{2}\right)$ measured using the University of Leicester's filter radiometer (FR) and diode array spectroradiometer (SR). The two Julian day ranges refer to data from the first and second halves of the campaign, respectively.

observed due to the modification of the spectral actinic flux by clouds not being factored into the filter radiometer calibration (Monks et al., 2004). For $j$ - $\left(\mathrm{NO}_{2}\right)$ there is excellent agreement between the SR and FR data. The slight curvature at high SZAs seen in Fig. 13a for $j-\left(\mathrm{O}^{1} \mathrm{D}\right)$ and the significant scatter at all SZAs are both absent, because the action spectrum for $j$ - $\left(\mathrm{NO}_{2}\right),\left(\sigma_{\mathrm{NO} 2}(\lambda) \times \phi_{\mathrm{O} 3 \mathrm{P}}(\lambda) \times F(\lambda)\right)$ occurs at longer wavelengths (290-420 nm) compared with that for $j$ $\mathrm{O}^{1} \mathrm{D}(280-320 \mathrm{~nm})$, and so is much less affected by changes in absorption from variations in the overhead $\mathrm{O}_{3}$ column, increased optical path-length at high SZAs or modifications by clouds.

Uninterrupted measurements over 39 days were recorded, however, some short term gaps in the SR measurements occurred owing to instrumental problems. For the constrained box modelling studies, missing SR data were estimated using the FR measurements using the correlation method as described in Sommariva et al. (2006b). Figure 14a shows actinic flux, and Figs. $14 \mathrm{~b}$ and $\mathrm{c}$ diurnal variations for $j-\left(\mathrm{O}^{1} \mathrm{D}\right)$, $j$-( $\left.\mathrm{NO}_{2}\right), j$-(HONO), $j$-(HCHO) (radical $\mathrm{H}+\mathrm{HCO}$ and nonradical $\mathrm{CO}+\mathrm{H}_{2}$ channels $), j-\left(\mathrm{CH}_{3} \mathrm{CHO}\right)$ and $j-\left(\mathrm{CH}_{3} \mathrm{COCH}_{3}\right)$, all calculated from the actinic flux, for 18 August 2002, which was typical of the clean conditions encountered.

The structure in the mornings is due to the presence of clouds which attenuate the radiation (Monks et al., 2004). $j$ (HCHO_NR) (non-radical), and $j$-(HCHO_R) (radical) show wider profiles compared with $j-\left(\mathrm{O}^{1} \mathrm{D}\right)$ because absorption occurs at longer wavelengths. The measurement of a wider range of photolysis frequencies compared with previous campaigns at Mace Head has assisted enormously with the quantification of the budget for many species, especially free-radicals, and has enabled photolysis frequencies required by the model to be inputted directly, reducing model uncertainties. Previously, $j$-values other than $j-\left(\mathrm{O}^{1} \mathrm{D}\right)$ and $j$ - $\left(\mathrm{NO}_{2}\right)$ had to be calculated from $j$ - $\left(\mathrm{O}^{1} \mathrm{D}\right)$ and/or $j$ - $\left(\mathrm{NO}_{2}\right)$ whilst making assumptions about attenuation factors at different wavelengths (Carslaw et al., 2002, 1999a).

\section{$3.11 \mathrm{OH}, \mathrm{HO}_{2}$ and $\left(\mathrm{HO}_{2}+\Sigma \mathrm{RO}_{2}\right)$ free-radicals}

$\mathrm{OH}$ and $\mathrm{HO}_{2}$ measurements were made simultaneously with $30 \mathrm{~s}$ time-resolution using two independent fluorescence cells, and are discussed in Smith et al. (2006). The FAGE (Fluorescence Assay by Gas Expansion) (Hard et al., 1984) technique uses laser-induced fluorescence spectroscopy at low-pressure and the instrument was located in Container 1 (Fig. 1, panel b), with considerably improved detection limits compared with previous deployments at Mace Head (Table 1). Measurements of the sum of $\mathrm{HO}_{2}$ and $\Sigma \mathrm{RO}_{2}$ (where $\mathrm{R}$ represents an organic group, for example $\mathrm{CH}_{3}$ ) were reported with 1 min time-resolution by a dual channel PERCA (PEroxy Radical Chemical Amplifier). Full details of the PERCA instrument can be found in Fleming et al. (2005), with the major improvement from previous deployments being the addition of a second channel which enables a continuous measure of the background signal, improving signal-tonoise ratios. Comparisons for $\mathrm{OH}, \mathrm{HO}_{2}$ and $\mathrm{HO}_{2}+\Sigma \mathrm{RO}_{2}$ are made with the calculations of a detailed model based on the MCM in later papers of this issue (Sommariva et al., 2005a, 2006b; Fleming et al., 2005). Further discussion of the coupling observed between the $\mathrm{HO}_{\mathrm{x}}$ and $\mathrm{XO}_{\mathrm{x}}$ families can be found in Bloss et al. (2005). 

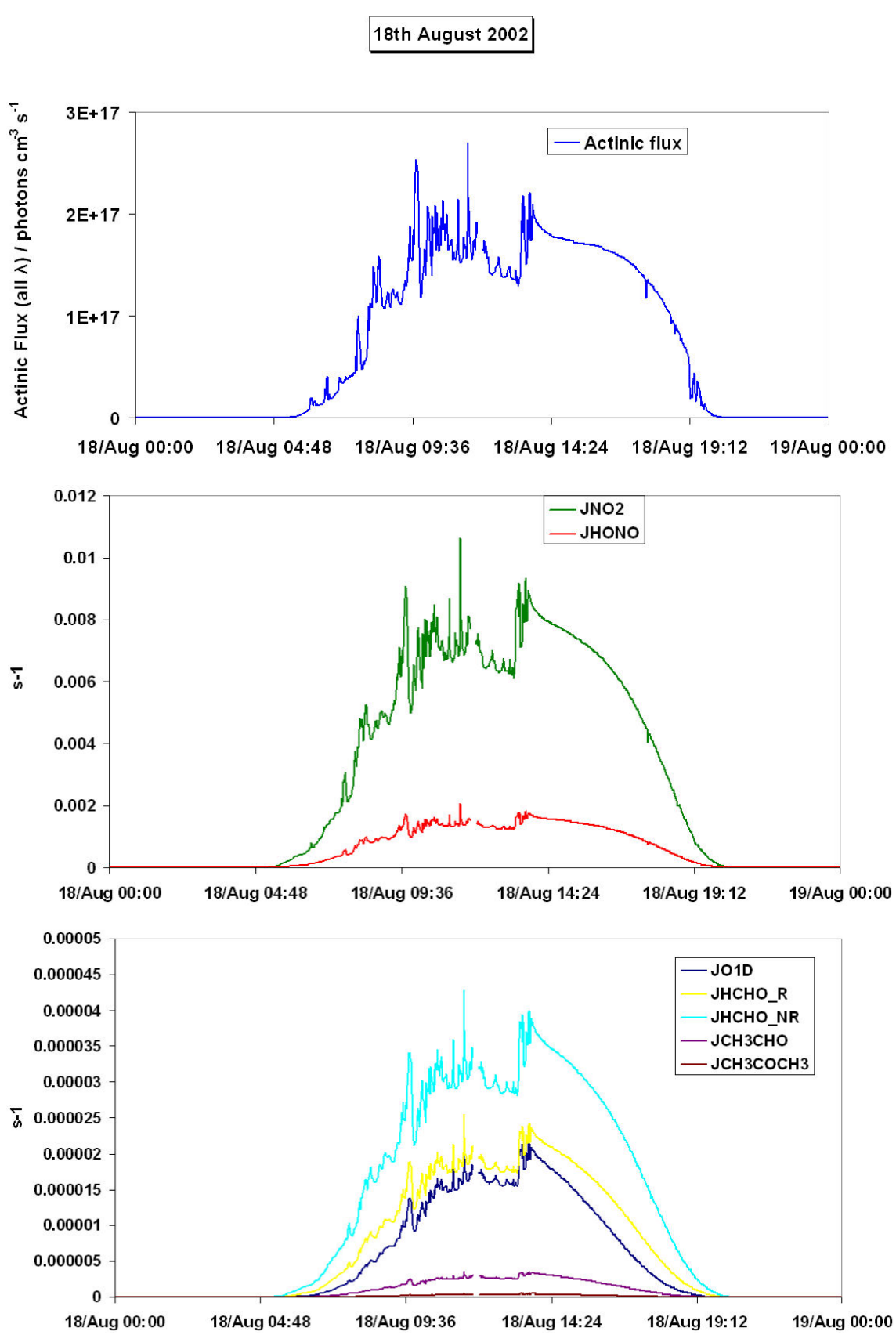

Fig. 14. (a): Actinic flux, (b): $j$-( $\left.\mathrm{NO}_{2}\right)$ and $j-(\mathrm{HONO}),(\mathbf{c}): j-\left(\mathrm{O}_{1} \mathrm{D}\right), j$-(HCHO)NR (non-radical, $\left.\mathrm{HCHO}+\mathrm{hv} \rightarrow \mathrm{H}_{2}+\mathrm{CO}\right), j$-(HCHO)R(radical, $\left.\mathrm{HCHO}+\mathrm{hv} \rightarrow \mathrm{HCO}+\mathrm{H} \rightarrow \mathrm{HO}_{2}+\mathrm{HO}_{2}+\mathrm{CO}\right), j-\left(\mathrm{CH}_{3} \mathrm{CHO}\right)$, and $j-\left(\mathrm{CH}_{3} \mathrm{COCH}_{3}\right)$ for a clean day 18 August 2002.

\subsection{Measurements of aerosols}

3.12.1 Aerosol size- and number-distributions and hygroscopic growth factors

As can be seen in Table 1, a wide range of instrumentation was deployed during NAMBLEX by NUI, Galway, TNO Holland and the Universities of Manchester, Birmingham, Edinburgh, and Leeds to measure a large number of aerosol parameters. Number densities of aerosols as a function of their dry and wet diameters from $3 \mathrm{~nm}$ to $20 \mu \mathrm{m}$ diameter were made at several heights using a scanning mobility particle sizer (SMPS), a Grimm optical particle counter (OPC), a differential mobility particle sizer (DMPS), a forward scattering spectrometer probe (FSSP) and other optical particle counters, and are discussed in full by Coe et al. (2005). Most measurements were made at two heights ( 7 and $22 \mathrm{~m}$ ) using a home-built sampling manifold attached to the $23 \mathrm{~m}$ tower 
(Fig. 1). Coe et al. (2005) also investigate if the aerosol size distribution is affected by local effects induced by changes in tide height. Aerosol optical depth was measured using BBCRDS by the University of Cambridge and reported within Bitter et al. (2006) ${ }^{1}$. The sea spray source function, describing the amount of sea spray aerosol produced at the sea surface as a function of environmental conditions, is highly uncertain. To better constrain these, a sea spray flux package was used. Vertical wind speed was measured with a sonic anemometer. Concentrations of particles larger than $10 \mathrm{~nm}$ were measured with a CPC. Size segregated measurements of sea spray aerosol were made with an optical particle counter with an inlet heated to $600^{\circ} \mathrm{C}$ which effectively removed all volatile aerosol components other than sea spray, as confirmed by inlet temperature scans up to $900^{\circ} \mathrm{C}$. Due to losses in the inlet system, only submicron particles were retained. Their concentrations were binned in a few size ranges. The covariance of particle concentrations and vertical flow velocity provides the sea spray fluxes (De Leeuw et al., 2003) and the total aerosol fluxes (Nilsson et al., 2001; Geever et al., 2005) which are further analysed as a function of (micro-)meteorological and oceanographic parameters to further constrain the source function. Cloud condensation nuclei $(\mathrm{CCN})$, a subset of condensation nuclei " $\mathrm{CN}$ ", provide surfaces upon which water vapour can condense to create cloud droplets, are formed from a variety of nucleation sources including dust, pollen, smoke, sea-salt aerosols from ocean spray and sulphate aerosols. Three sizes of CN were measured during NAMBLEX using CPCs (TSI 3025, $>3 \mathrm{~nm}$, TSI $3010 \mathrm{CPC}>5 \mathrm{~nm}$, and TSI $3010 \mathrm{CPC}>10 \mathrm{~nm}$ ). Similar to previous campaigns the number concentrations $\left(\mathrm{cm}^{-3}\right)$ for $>3 \mathrm{~nm}$ particles correlated with tidal height with enhanced numbers of particles (particle bursts) occurring at low tides during the daytime, particularly in air which had approached the site along the coast, and hence had been exposed to the inter-tidal region for longer periods (north west or south west air masses) (Grenfell et al., 1999). In SaizLopez et al. (2006a) a model involving nucleation of iodine species is developed to predict the formation of $\mathrm{CN}$.

A model of heterogeneous uptake (Schwartz and Freiberg, 1984) that takes into account mass transfer to the particle surface as well as mass accommodation at the surface has been calculated for a range of accommodation coefficients that are representative of key species in the MBL (Bloss et al., 2005; Coe et al., 2005). The use of real-time measured size- and number-distributions represents a considerable advance on merely using the total aerosol surface area to calculate heterogeneous loss rates, and the model considers explicitly the mass transfer limitation for gases with high accommodation onto coarse mode aerosol.
3.12.2 Aerosol composition as a function of size. Realtime and off-line methods

Perhaps the most exciting addition to the arsenal of aerosol measurements compared with previous campaigns at Mace Head was the deployment of two complementary aerosol mass spectrometers. The first, an Aerodyne Inc. aerosol mass spectrometer (AMS) was used to make composition measurements in real-time of aerosols as a function of size (from $40 \mathrm{~nm}$ to $1 \mu \mathrm{m}$ ). Aerosol size is related to the arrival time of particles at a heater on which they are flash volatilised, and the non-refractory components are analysed using a quadrupole mass spectrometer. Various mass-tocharge $(\mathrm{m} / \mathrm{z})$ ratios are used to identify specific constituents within the aerosol (nitrate, sulphate, ammonium, organic, chloride), and the signals at these $\mathrm{m} / \mathrm{z}$ ratios are calibrated using ammonium nitrate particles of a known size (Allan et al., 2003). Hence quantitative information is gained on composition, but averaged over many aerosols of a given size. The second, a TSI Inc. Aerosol Time-of-Flight Mass Spectrometer (ATOFMS, Model 3800-100), uses laser-scattering at two positions within the aerosol sampling inlet to determine the diameter of a given aerosol via its velocity, and the same aerosol is then vaporised and ionised using a pulsed YAG laser, followed by measurement of the mass spectrum of positive and negative ions using a time-of-flight mass spectrometer. Hence the composition of a single particle is determined, with peaks at specific $m / z$ ratios used to identify various constituents. The ATOFMS was deployed between 1-21 August and can determine the composition of aerosol particles in the size range $200 \mathrm{~nm}-3 \mu \mathrm{m}$. As discussed in Dall'Osto et al. (2004, 2005), a very large number of constituents can be identified (including a wide range of metals), including refractory materials (so useful for sea-salt aerosols). Aerosols were also trapped onto filters using either a Micro Orifice Uniform Deposit Impactor (MOUDI) impactor or a $\mathrm{Hi}$-Vol sampler for a period of $24 \mathrm{~h}$ and subsequently analysed using ion chromatography for various species over a limited range of aerosol diameters. Comparisons of composition (e.g. for aerosol $\mathrm{SO}_{4}^{2-}$ ) were made between the mass spectrometers and the MOUDI impactor/Hi-Vol instruments. Also, comparison of ATOFMS single-particle composition and impactor (averaged) data gives information on whether the aerosols are internally mixed (composition of all particles is the same) or externally mixed (composition of different particles is very different). The use of aerosol composition as a tracer of air mass history is also discussed in Coe et al. (2005). Filter samples were also used subsequently to the NAMBLEX campaign to trap atmospheric molecular iodine, and following analysis could be compared to the measurements using DOAS and BBCRDS (Saiz-Lopez et al., 2006a). 
Table 2. Meteorological summary from (Norton et al., 2006).

\begin{tabular}{cll}
\hline Period & Date & Conditions \\
\hline 1 & 1-5 August & Complex meteorology, weak winds from the north east \\
2 & 6-11 August & Westerly/north westerly wind \\
3 & 12-17 August & Azores high retreated south and depressions crossed Ireland from West \\
4 & 18-27 August & Stagnant, anti-cyclonic conditions until 27th \\
5 & 28-30 August & Return to westerly wind and unsettled weather \\
\hline
\end{tabular}

3.13 Supporting measurements using an airborne platform during NAMBLEX

An aircraft campaign SNAP (Supporting NAMBLEX from an Airborne Platform) was run concurrently with the groundbased campaign in order to determine if the composition of the air sampled at Mace Head was representative of the coastal and open ocean region. A total of four flights were carried out using the NERC Dornier 228-101 research aircraft. Two flights have been reported, the first on the $8 \mathrm{Au}-$ gust 2002, when the aircraft was flown in a North-South direction along the coastline centering on Mace Head at various levels between $390 \mathrm{~m}$ and $3.2 \mathrm{~km}$, and for the second flight on 10 August 2002, the aircraft flew $\sim 320 \mathrm{~km}$ west from the Mace Head observatory to the continental shelf region of the Atlantic Ocean at a height of $3 \mathrm{~km}$ and returned at a height of $400 \mathrm{~m} . \mathrm{O}_{3}$ and $\mathrm{CO}$ concentrations were measured in situ on both flights whilst Whole Air Sampling (WAS) flasks were filled in-flight for the subsequent measurement of $\mathrm{C}_{2}-\mathrm{C}_{7}$ NMHCs and DMS concentrations using a GC-FID system on the ground. The data obtained on both flights was compared to the simultaneously obtained ground measurements and the results are discussed in Purvis et al. (2005).

\section{A climatology of the meteorological conditions for the duration of the campaign}

In the following paper of this issue, Norton et al. (2006), have interpreted synoptic charts and meteorological measurements in order to divide the NAMBLEX campaign into five periods of similar synoptic type, as summarised in Table 2. This meteorological climatology aids interpretation of the chemical and aerosol measurements, and is complementary to the chemical climatology presented in Sect. 6 below.

\section{Trajectory analysis of air masses arriving at Mace Head during NAMBLEX}

Back trajectory calculations, usually for a period of 5 days, provide information about the evolution of the position and altitude of the sampled air prior to sampling at the site, and are very commonly used to aid interpretation of the vari- ability of measurements of atmospheric composition (Derwent and Davies, 1994; Lewis et al., 1999). Such an analysis combined with a knowledge of the atmospheric lifetime of the trace species in question enables allocation of possible source origins. Trajectories arriving at the site during NAMBLEX were calculated using winds from the operational atmospheric analysis produced by the European Centre for Medium-Range Weather Forecasts (ECMWF, 1995). The latitude, longitude and pressure coordinates for a given air parcel were calculated every $30 \mathrm{~min}$, but the trajectory points are only plotted every $6 \mathrm{~h}$ in Fig. 17. Back trajectories were initiated from a column of points above Mace Head at hourly intervals. Generally for these analyses only trajectories from the $500 \mathrm{~m}$ level are used. This level was chosen because it usually lies within the daytime boundary layer (see Figs. 7 10 in Norton et al., 2006) and therefore in rapid contact with the surface through turbulent mixing, but is more representative of the average resolved-scale flow advecting air into the Mace Head area.

5.1 Consistency of trajectory analyses and local meteorological measurements

Norton et al. (2006) compared observations of wind speed and direction from anemometers on the mast and from a wind profiler with ECMWF analyses at $10 \mathrm{~m}$ and $1100 \mathrm{~m}$. Throughout most of the NAMBLEX campaign there is remarkably good agreement between the analyses and observations. In addition, during the westerly Periods 2,3 and 5 (see Table 2) the wind direction at $10 \mathrm{~m}$ is almost the same as at $1100 \mathrm{~m}$ explaining the insensitivity of the trajectory origins to the choice of arrival level. However, on some occasions the local winds were decoupled from the synoptic scale flow (during Periods 1 and 4), when the arrival direction of the back trajectories following the flow resolved in the ECMWF analyses were not in agreement with the measured wind direction at the site. This observation has been attributed to the presence of weak sea breezes as evidenced by the diurnal variation of wind direction and speed observed between $7 \mathrm{~m}$ and $24 \mathrm{~m}$ on the met mast. However, at $1100 \mathrm{~m}$ the ECMWF analyses were in good agreement with the wind profiler retrievals. The sea breeze occurs in a shallow layer that grows throughout the afternoon but never exceeds $800 \mathrm{~m}$ 


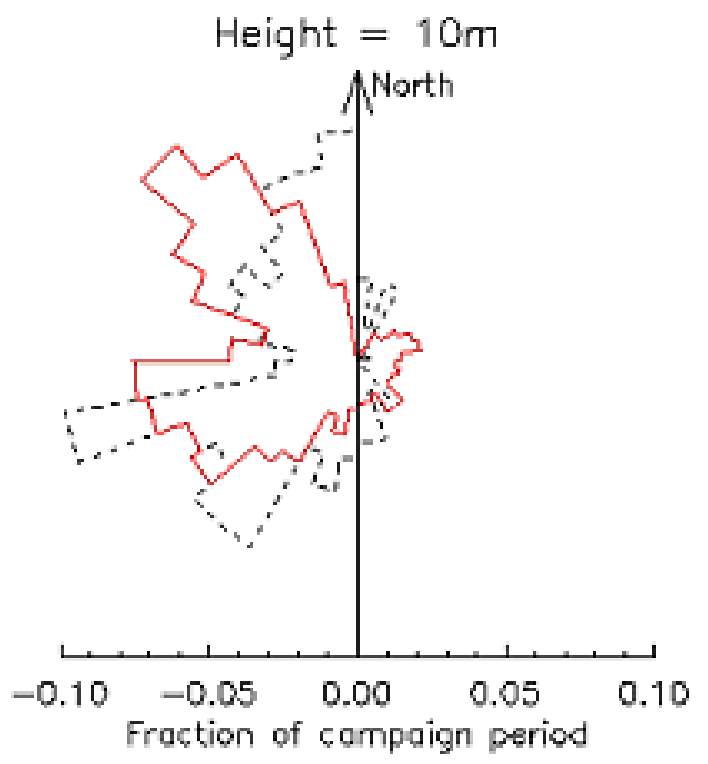

Fig. 15. Wind Rose showing the frequency of different wind directions for the local measurement from the met mast (red) and for the ECMWF analyses at $10 \mathrm{~m}$ (dashed).

(on 4 August in Fig. 7 of Norton et al., 2006). Interestingly, the "sea breeze periods" (2-4 and 26-27 August) occur when the flow above the boundary layer (as seen around $1 \mathrm{~km}$ by the wind profiler and in ECMWF analyses) is northerly to northeasterly. It is likely that the Connemara Mountains (about $30 \mathrm{~km}$ northeast of Mace Head with peak heights of $700-800 \mathrm{~m}$ ) block the low level flow and cause air to approach the site from the east or northwest depending on time of day, instead of from the north (Fig. 15). As a result, the local wind direction measured on the mast was never from the North during NAMBLEX.

5.2 Densities of origin for the sampled air at Mace Head during NAMBLEX

Methven et al. (2001) describe the use of back trajectories to create density of origin maps for a given campaign, and are shown for 5 and 10 day back trajectories for NAMBLEX in Figs. 16a and b, respectively. It is clear that although the spread of origins increases for 10 day trajectories, the change is not large from 5 days indicating that these low level trajectories meander a great deal: they do not systematically come from further south or west, except over Northern Canada. It is difficult therefore to solely use these plots as a means of classification. However, the analysis does illustrate that during NAMBLEX the site experienced a high proportion of air masses which had originated in the west. Figures 16c-f show similar plots of origin-averaged fields calculated for origin pressure (i.e. pressure at the beginning of the trajectory), $\mathrm{O}_{3}$, acetylene and DMS. Trajectories from the $500 \mathrm{~m}$ level were used to calculate these although the origin averages are quite insensitive to the choice of level between $10 \mathrm{~m}$ and $800 \mathrm{~m}$. Except for pressure (Fig. 16c), the plots rely on the measurements made at the site during the campaign. Care must be taken when interpreting these plots (Figs. 16d-f) as they show the concentrations measured at the site as a function of where the air mass has originated from, and injections into the air mass may have occurred at any time along the trajectory, not only at the origin (Methven et al., 2001).

\subsection{Sampling of clean air versus polluted air}

As in previous campaigns at Mace Head the "clean" air sector was defined as between $180^{\circ}$ and $300^{\circ}$, occurring on average $52 \%$ of the time (Jennings et al., 2003), and during NAMBLEX local wind direction measurements gave a considerably higher value of $80 \%$ in this sector. The polluted air sector is defined for a wind direction data between $>45^{\circ}$ and $<135^{\circ}$. Non-methane hydrocarbons (NMHC) have widely varying anthropogenic and biogenic sources and 1/e atmospheric lifetimes with respect to reaction with $\mathrm{OH}$ (assuming $[\mathrm{OH}]=1 \times 10^{6}$ molecule $\left.\mathrm{cm}^{-3}\right)$, ranging from $\sim 2 \mathrm{~h}$ for isoprene $\left(k_{\mathrm{OH}}=1.01 \times 10^{-10} \mathrm{~cm}^{3}\right.$ molecule $\left.{ }^{-1} \mathrm{~s}^{-1}\right)$ (Atkinson et al., 1997) to $\sim 1$ month for ethane $\left(k_{\mathrm{OH}}=2.68 \times 10^{-13} \mathrm{~cm}^{3}\right.$ molecule ${ }^{-1} \mathrm{~s}^{-1}$ ) (Atkinson et al., 1997), making them particularly useful indicators of air mass history (Jobson et al., 1998). Figure 16e shows the origin-averaged plot for observed acetylene, emitted almost exclusively from vehicle exhausts and so is a tracer for anthropogenic pollution. Considering this map there were three areas showing high concentration, (i) Northern Europe, (ii) Canada and (iii) Greenland, however to reiterate, this is not necessarily where the acetylene measured at the site was originally produced, only where the 5-day trajectory originated. Figure $16 \mathrm{f}$ shows the origin-averaged plot for DMS, having a sole source from the breakdown of phytoplankton in the ocean. Lifetimes of these species with respect to removal by $\mathrm{OH}$ $\left([\mathrm{OH}]=1 \times 10^{6}\right.$ molecule $\left.\mathrm{cm}^{-3}\right)$ are two days and two weeks for DMS and acetylene respectively $\left(k_{\mathrm{OH}, \mathrm{DMS}}=6.3 \times 10^{-12}\right.$ and $k_{\mathrm{OH}, \mathrm{C} 2 \mathrm{H} 2}=8.2 \times 10^{-13} \mathrm{~cm}^{3}$ molecule ${ }^{-1} \mathrm{~s}^{-1}$ ) (Atkinson et al., 1997). Figure 6 showed time-series for these species and highlights the existence of a strong anti-correlation in their concentrations throughout the entire campaign. It is clearly evident when the air was of marine or continental origin.

\section{An air mass classification based on chemical measure- ments}

Although rather subjective, the behaviour of NMHC species such as acetylene and DMS considered alongside those of $\mathrm{CH}_{4}, \mathrm{CO}, \mathrm{NO}_{\mathrm{x}}, \mathrm{NO}_{\mathrm{y}}$ and $\mathrm{O}_{3}$ can provide further clues as to the distribution of emission sources before or during the 5 days prior to sampling. This analysis can be used to produce a chemical climatology for the duration of the campaign (Evans et al., 2000) to be used in conjunction with 
(a)

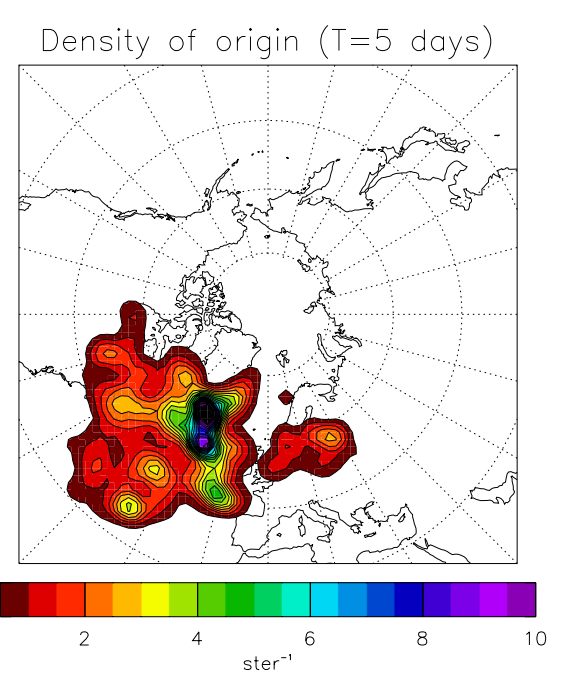

(c)

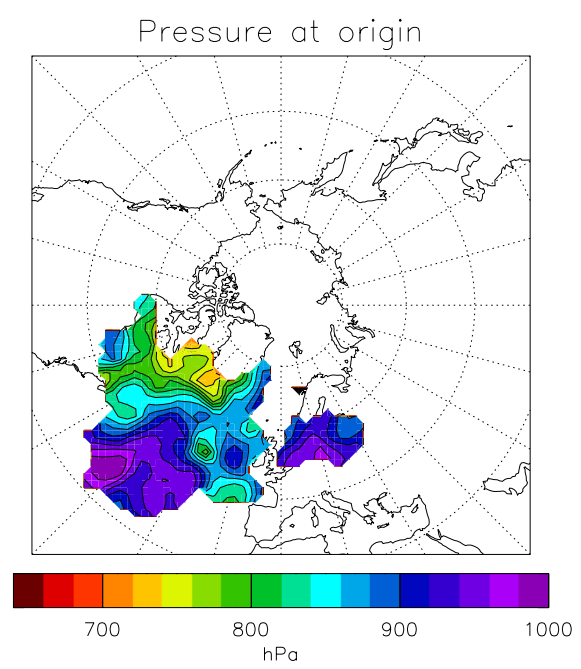

(e)

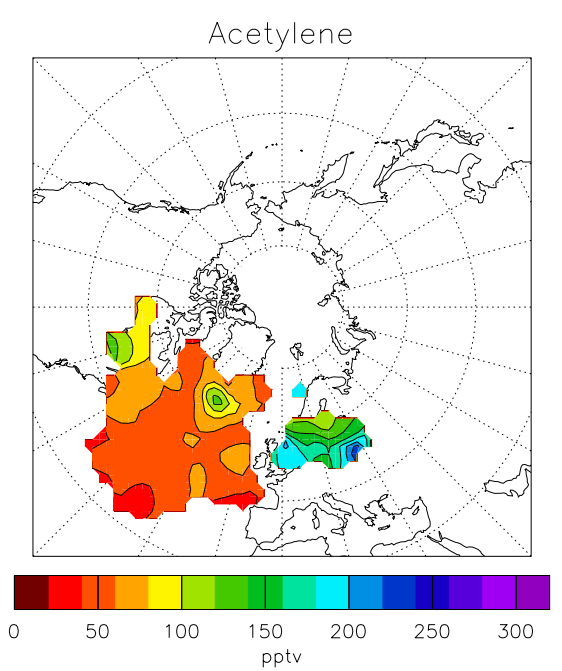

(b)

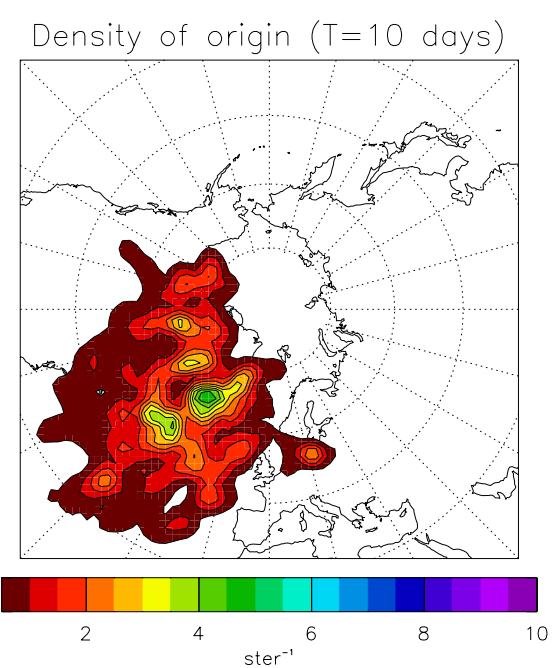

(d)

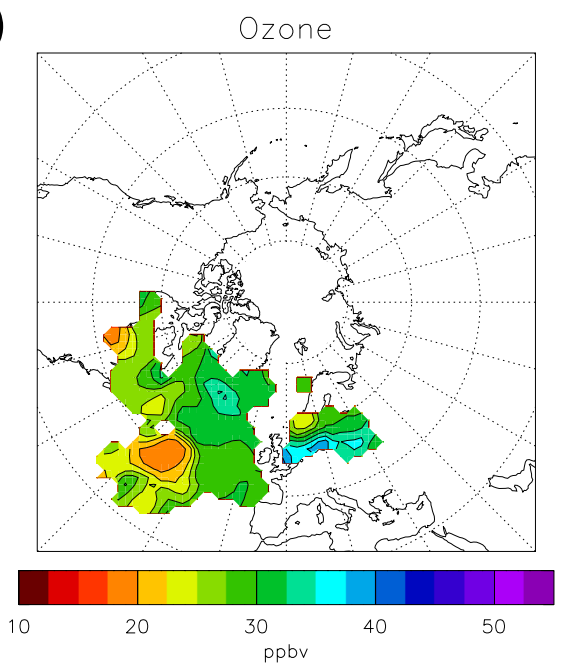

(f)

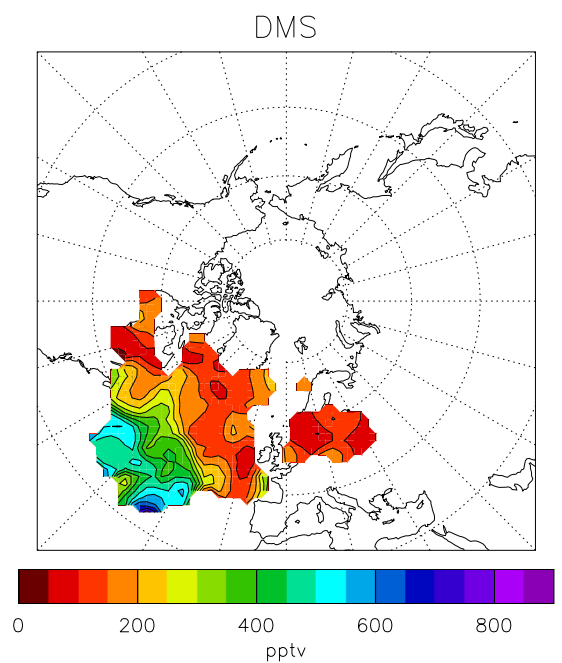

Fig. 16. (a): Density of origin plot for 5-day back trajectories from $500 \mathrm{~m}$ above Mace Head during NAMBLEX, (b): As (a) but for 10 days, (c): Origin-averaged pressure at origin of air mass, (d): Origin-averaged ozone, (e): Origin-averaged acetylene, (f): Origin-averaged DMS. (c-f based on 5-day trajectories). 

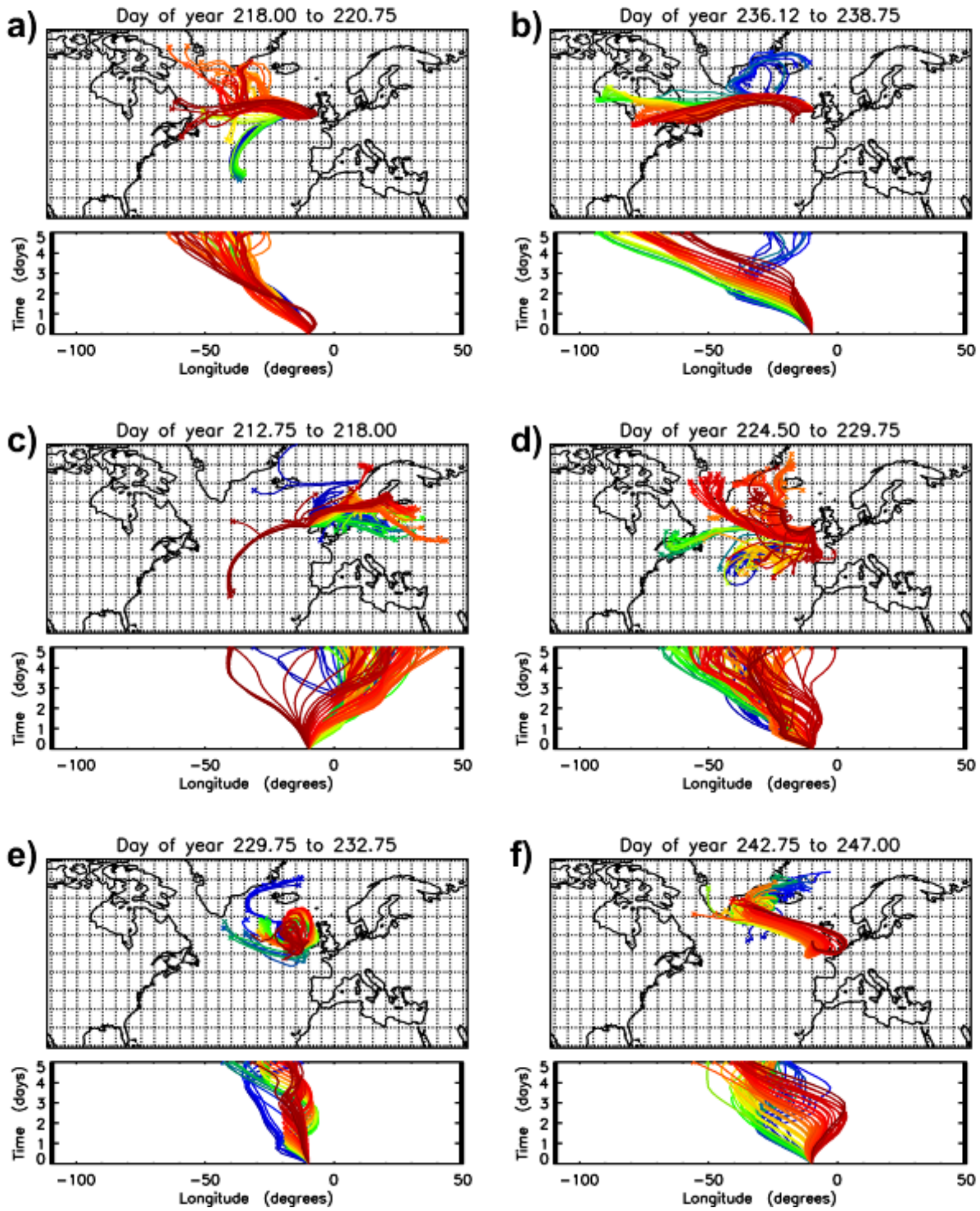

Fig. 17. Trajectories illustrating air flow during some periods of the 6 classifications. In all panels the colours correspond to time during the period (every hour) moving through the rainbow from blue to red. The classifications are based on the final day of the trajectories: (a) 00:00 UT 6 August-18:00 UT 8 August (Second W period), (b) 12:00 UT 24 August-18:00 UT 26 August (Third NW period), (c) 18:00 UT 31 August-00:00 UT 6 August (NE period), (d) 12:00 UT 12 August-18:00 UT 17 August (First SW period), (e) 18:00 UT 17 August-18:00 UT 20 August (Cyclonic period) (f) 18:00 UT 30 August-00:00 UT 4 September (Anti-cyclonic period). 
the meteorological data and back trajectories classifications. Other approaches have been to perform cluster analyses of the trajectories (Cape et al., 2000a) which are then used to bin chemical concentrations by air mass, rather than by concentrations of species. These are however, calculated without any consideration of the chemistry and so often lead to overlap in the classifications.

The chemical climatology analysis coupled with the ECMWF back trajectories ( 2 days before arrival), led to six classifications with the frequency of occurrence in parentheses: West (3), North West (3), North East (1), South West (2), Cyclonic (1) and Anti-cyclonic (1), which are described in subsequent sections below. The 6 classifications are shown in Fig. 17, and annotated labels for each air mass (W, NW, NE, SW, C, AC, respectively) have been added above the time-series in Figs. 4, 6, 7, 8, 9, 10, 11, and 12. Figure 18 shows the fraction of the NAMBLEX campaign for which each classification of air mass was experienced.

\subsection{Westerly}

There were no measurements of the parameters used for the meteorological classification (Norton et al., 2006) prior to 1 August, however with the use of the trajectory calculations, local wind speed and wind direction data in conjunction with measurements of NHMCs, $\mathrm{CH}_{4}, \mathrm{CO}, \mathrm{NO}_{\mathrm{x}}, \mathrm{NO}_{\mathrm{y}}$ and $\mathrm{O}_{3}$, it was possible to classify the air experienced by the site between the 24 July and the 28 July as being of westerly origin. In addition, westerly conditions dominated between the 6 and the 8 August (in agreement with the meteorological analysis (Norton et al., 2006), and again between the 27 and the 30 August. During all three of these periods DMS concentrations were the highest observed during the campaign (up to 1.9 ppbv, Fig. 16f) whilst the concentrations of other NMHC were at their lowest (Figs. 6, 8 and 9, 16e). The average [DMS] of $188 \pm 112$ pptv was higher than previous observations at this site (Lewis et al., 1997), consistent with the suggestion that the "cleaner" marine-influenced air dominated during NAMBLEX.

Longer-lived species such as ethane, propane, $\mathrm{CH}_{4}$ and $\mathrm{CO}$ show large drops to close to their minimum concentrations during these periods supporting the assumption of the air being clean and well-processed (Figs. 6 and 8). Similar to previous campaigns at this site, $\mathrm{O}_{3}$ behaves in a comparable way, displaying concentrations $<15 \mathrm{ppbv}$, reflecting photochemical loss in humid air and deposition to the ocean (Fig. 4). In addition, during these periods there were very few contaminant peaks recorded in the $\mathrm{NO} / \mathrm{NO}_{2}$ data (Fig. 10), and concentrations were similar to those measured previously at Mace Head in air classified as clean in the summer 1996 and in the spring 1997 ACSOE EASE deployments (Carslaw et al., 2002). During these low concentration periods the 5-day back trajectories show that the air has been transported from latitudes as far south as the Azores $\left(30^{\circ} \mathrm{N}\right)$

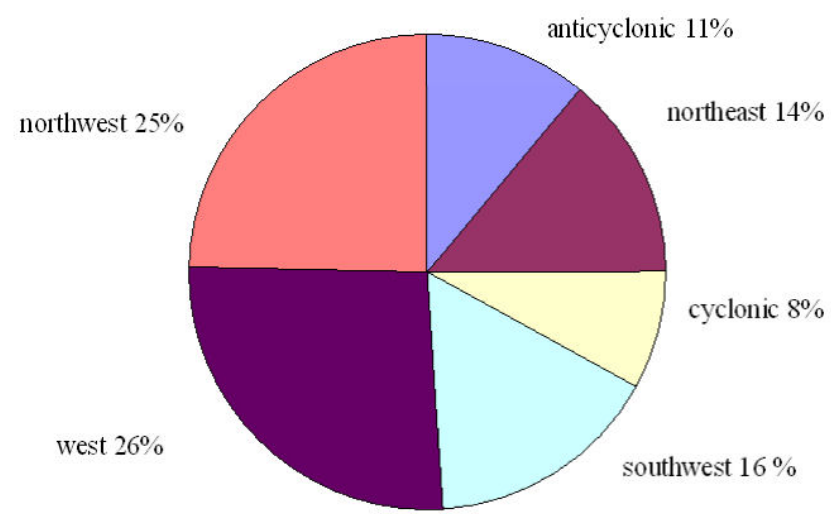

Fig. 18. The distribution of trajectory classifications during NAMBLEX.

similar to previous campaigns (Simmonds et al., 1997) and is illustrated by the blue/green trajectories on Fig. 17a.

\subsection{North westerly}

According to trajectories late on 28 July, the air swung round towards the north to give a more coastally influenced north westerly air flow. The air was still fairly clean during this time, with characteristically similar drops in the concentrations of long-lived species to those observed in the westerly periods (Figs. 6 and 8). Due to its northerly coastal approach however, the air also showed evidence of localised pollution, manifested as "spikes" of high concentration visible particularly in ethene and propene which peaked at $157 \mathrm{pptv}$ and 52 pptv, respectively (Fig. 9). Isoprene was present in this air mass with maximum concentrations in the mid-afternoons, indicating that this biogenically produced species may have a source close to the site, consistent with previous campaigns (Carslaw et al., 2000). Similar north westerly conditions were observed between 8 and 12 August and also between the 24 and 27 August with correspondingly similar chemical signatures in these species. During this latter half of 26 August much higher acetylene concentrations were measured (Sect. 5.3, and Fig. 16e). Red trajectories in Fig. 17b correspond to this "pollution" event, originating from cities around Lake Superior between 6 and 6.5 days prior to Mace Head (Fig. 16b).

\subsection{North easterly}

Although the meteorology for the period between 1 and 5 August implies weak north-easterly winds, the high concentrations of VOC species (benzene and toluene are up to $170 \mathrm{pptv}$ and up to $201 \mathrm{pptv}$, respectively) and CO (up to $167 \mathrm{ppbv}$ ) at this time strongly indicates that the air received at the site had been influenced by the continent. Indeed the back trajectories show origins in Northern Europe (Fig. 17c). In addition, the $\mathrm{NO} / \mathrm{NO}_{2}$ data pattern is very similar to other 

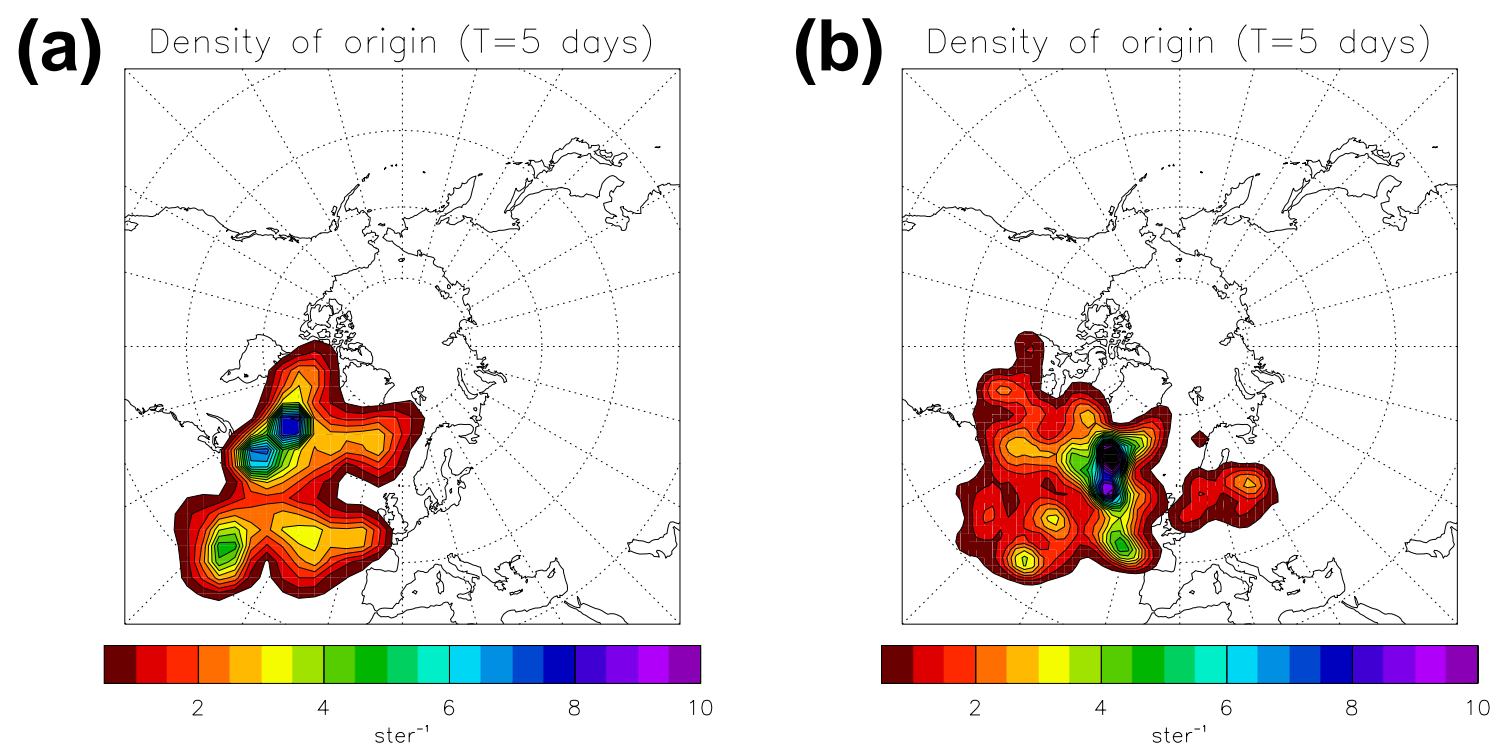

Fig. 19. Density of origin plots using 5-day back trajectories for EASE96 (left) (a) and NAMBLEX (right) (b).

tracers of anthropogenic emissions such as propane (Figs. 6 and 10) with higher values during this period. The pollution is also clear in the origin-averaged map for acetylene (Fig. 16e), and reflected for $\mathrm{O}_{3}$ (Fig. 16d), whose maximum concentrations are for air originating in Europe with additional formation of $\mathrm{O}_{3}$ from precursor NMHCs and $\mathrm{CO}$ en route to Mace Head. The concentrations of long-lived species such as methane, ethane and propane are unlikely to be influenced by local emissions during periods of weak winds close to the site, and so the trajectory analysis is valid for these species. The local meteorology and sea breeze effects will, however, impact the concentrations of shorter lived species, for example alkenes, all of which showed higher variability at this time (Fig. 9).

\subsection{South westerly}

Between the 6 and 17 August the analysis of the back trajectories was in agreement with the meteorological analysis (Table 2) (Norton et al., 2006). A south westerly classification is given for the period between the 12 and 17 August and also for a period occurring later in the campaign, between the 21 and the 24 August, for which unfortunately there are limited wind profiler data. During these periods the air was generally clean (Sect. 5.3), with high DMS and low acetylene concentrations (Figs. 6, 16e and f) and similar to the north westerly classified periods, isoprene was also observed. Observed $\left[\mathrm{O}_{3}\right]$ and $[\mathrm{CO}]$ were lowest during these periods particularly at times corresponding to the blue trajectories on Fig. 17 d.

\subsection{Cyclonic}

Cyclonic conditions dominated the period between the 17 and 21 August, when a region of low pressure caused the air to spend at least 5 days circling over the ocean (Figs. 16c and 17e). This period proved to be a good case study for investigating DMS flux from the ocean and methanol deposition to the ocean as the successive trajectories showed a varying wind speed throughout this period (Carpenter et al., 2004a; Lewis et al., 2005).

The sustained period of air originating from the clean oceanic sector, combined with generally sunny weather enabled a long time-series of $\mathrm{OH}, \mathrm{HO}_{2}$ and $\mathrm{HO}_{2}+\Sigma \mathrm{RO}_{2}$ to be measured, together with a comprehensive suite of supporting measurements to constrain zero-dimensional models. For example, it was possible to compare modelled and measured concentrations for all these species continuously for daylight hours on 7 consecutive days between 15-22 August (as well as other days) (Sommariva et al., 2006b; Fleming et al., 2005; Smith et al., 2006).

\subsection{Anticyclonic}

The end of the campaign (30 August-3 September) was influenced by the build up of generally anticyclonic conditions over Ireland and the UK following the passage of a depression on 30 August. The hydrocarbon concentrations showed a strong increase (Figs. 6, 8 and 9) as the trajectories developed anticyclonic curvature bringing air from SE Greenland over the UK and mainland Ireland before reaching Mace Head (yellow to red in Fig. 17f). It is these trajectories that account for the high values close to Greenland in the originaveraged acetylene (Fig. 16e) and to a lesser extent in $\mathrm{O}_{3}$ (Fig. 17d). The pollution is not carried from Greenland but 


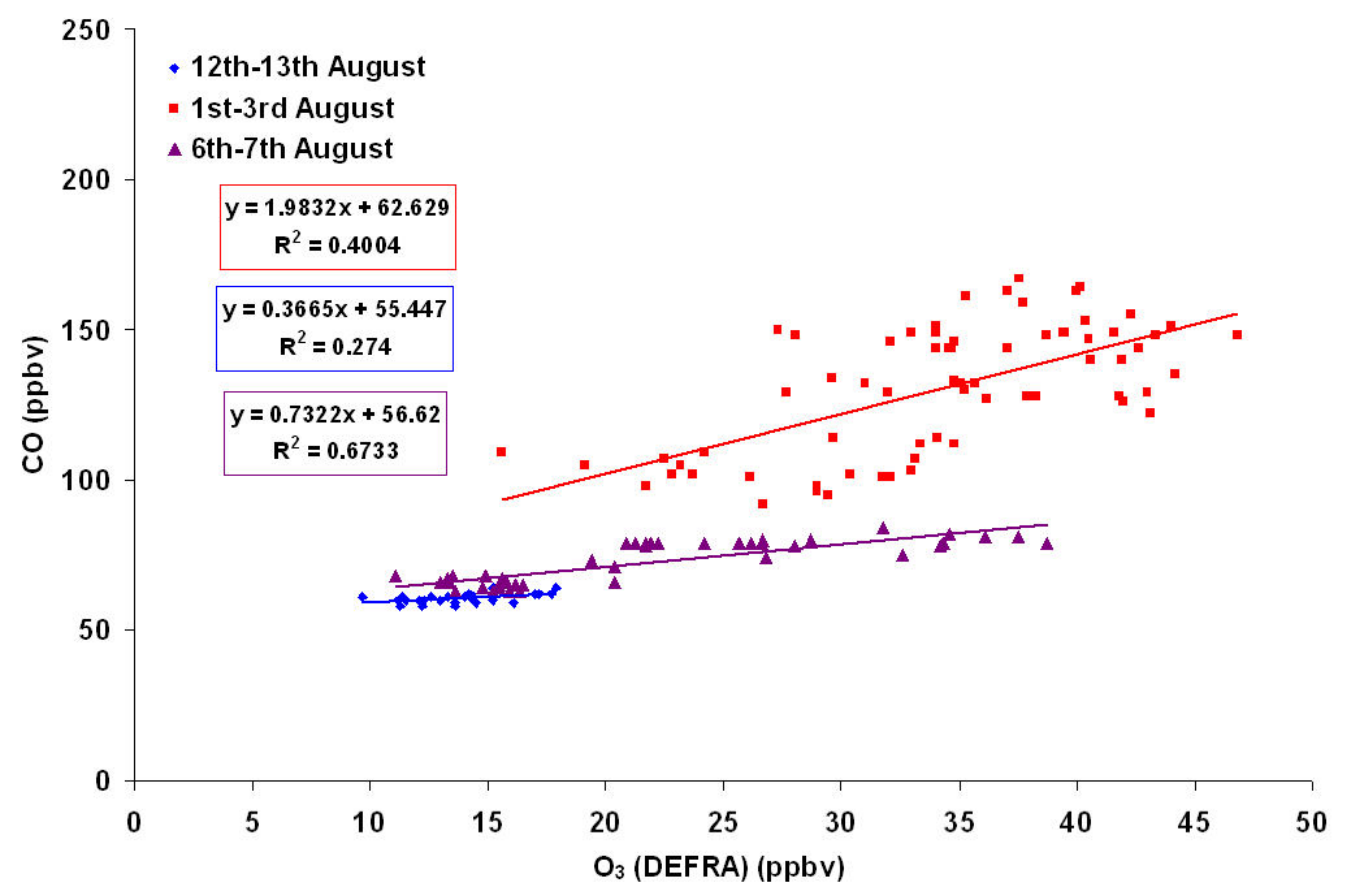

Fig. 20. $\mathrm{CO}$ versus $\mathrm{O}_{3}$ for a "polluted" period (1-3 August in red) a "clean" westerly period (6-7 August in purple), and for a "cleaner" south westerly period (12-13 August in blue) during NAMBLEX 2002.

is picked up over the UK and Ireland. This type of transport is similar to a sustained pollution event that was observed during EASE96, and is probably the most common type of polluted back trajectory from Mace Head (Methven et al., 2001).

\section{A comparison of conditions encountered during NAMBLEX with the EASE 96 summer campaign held at Mace Head}

The EASE96 campaign took place at Mace Head between the 8 July and 8 August 1996, falling $\sim 3$ weeks earlier than NAMBLEX. The density of origin plots for 5-day back trajectories for both campaigns are shown in Fig. 19. Generally the types of conditions experienced by the site were similar between the two campaigns, with classifications of easterly anti-cyclonic flow, south westerly flow and westerly flow existing for EASE96 (Evans et al., 2000). Differences arose in the frequency of conditions with the site suffering much less influence from the north and east during NAMBLEX, dominated instead by clean, westerly air. In addition, the spread of 5-day trajectory origins is less in the NAMBLEX illustrating that the air generally travelled a shorter distance over the 5 days than it did during EASE96.

Both $[\mathrm{CO}]$ and $\left[\mathrm{O}_{3}\right]$ were lower than those measured during EASE96, showing values of 91 and 29 ppbv compared to 125 and 34 ppbv, respectively (Evans et al., 2000). Models for EASE96 demonstrated that high levels of CO
(170 ppbv) leading to high levels of photochemically produced $\mathrm{O}_{3}(50 \mathrm{ppbv})$, were reported to be present in polluted easterly anti-cyclonic air masses at Mace Head, during which time $\mathrm{O}_{3}$ production was estimated to be more than $10 \mathrm{ppbv}$ per day (Evans et al., 2000). Derwent et al. has also used models to calculate $\mathrm{O}_{3}$ production from $\mathrm{CO}$ at Mace Head and found that during summertime there are clear frequent episodes of regional scale photochemical $\mathrm{O}_{3}$ production occurring particularly in polluted European air masses (Derwent et al., 1994, 1998). However, during periods of high $[\mathrm{CO}]$ in similar air masses during NAMBLEX, i.e. between 1 and 3 August when values reached $170 \mathrm{ppbv},\left[\mathrm{O}_{3}\right]$ remained within the error of the average value, at $34.2 \pm 6.6 \mathrm{ppbv}$ (average $29.0 \pm 6.5 \mathrm{ppbv}$ ) which may indicate that photochemical production was low at this time (Fig. 4). The 5-day back trajectory shows that during this episode continentally polluted air from Europe loops to the north before approaching Mace Head and so has a long passage over the sea. Considering this, it is likely that $\mathrm{O}_{3}$ loss via deposition to the ocean over the last few days prior to sampling offsets any photochemical production that may have occurred closer to the source, leading to a lower observed concentration. Derwent et al. used plots of $\mathrm{CO}$ versus $\mathrm{O}_{3}$ (for which the slope is a crude measure of $\mathrm{O}_{3}$ production) to further demonstrate photochemical production (Derwent et al., 1994). A similar plot is shown in Fig. 20 which although indicates that under these conditions a $37 \mathrm{ppbv}$ increase in $\mathrm{O}_{3}$ is associated with a $70 \mathrm{ppbv}$ increase in $\mathrm{CO}$, this may also be as a result of air mass mixing 

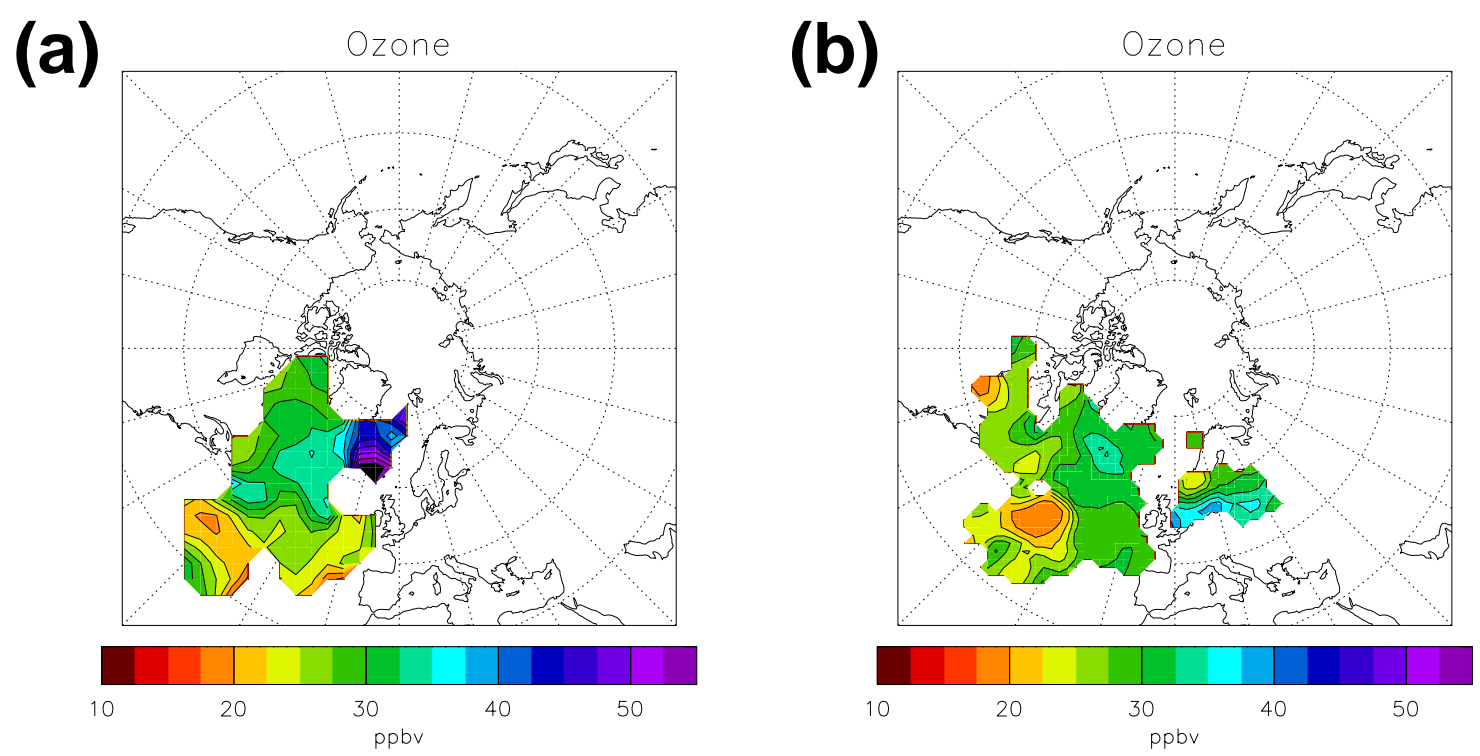

Fig. 21. Map of origin-averaged ozone. Plots showing average ozone data (DEFRA) for every hour during EASE96 on lefta and NAMBLEX on rightb which are used to label the origin of the 5 day back trajectory from Mace Head.

and models including other compounds are needed to reassure this assumption. From the maps of origin-averaged $\mathrm{O}_{3}$ for both campaigns (Fig. 21) it appears that periods of high $\mathrm{O}_{3}(>45 \mathrm{ppbv}$ ) only in fact occurred during EASE96 (blue areas) and were not a feature of NAMBLEX.

Under "clean" westerly conditions during NAMBLEX (e.g. between 6 and 7 August) when the air has not had any continental influence for at least 5 days, levels of $\mathrm{O}_{3}$ were lower but there is also a small positive correlation between $\mathrm{CO}$ and $\mathrm{O}_{3}$. Long-range transport in the form of perturbed $\mathrm{CO} / \mathrm{O}_{3}$ ratios, can allow pollution signatures to be seen in air received at Mace Head even after 5 days. There was a similar finding during the ICARTT Lagrangian experiment carried out over the Atlantic ocean in July 2004, when the same air mass was sampled at 5 points along its trajectory (pers. comm. Methven, 2005). Figure 20 also shows the CO versus $\mathrm{O}_{3}$ correlation for an even "cleaner" south westerly period. Along with $\mathrm{O}_{3}$ and $\mathrm{CO}, \mathrm{CH}_{4}$ and NMHC concentrations measured at the site were generally at their lowest during south westerly periods with campaign minima for $\mathrm{CH}_{4}$ of 1730 ppbv for EASE96 and 1746 ppbv for NAMBLEX.

The percentage of concentration variance in the observed time-series that can be explained by the average relationship between chemical composition and trajectory origin is also a useful metric, and can be estimated following Methven et al. (2001), and is given by the rank correlation squared between the observed time-series and its origin-averaged timeseries (Fig. 21). During EASE96 this parameter was calculated for $\mathrm{O}_{3}, \mathrm{CO}$ and $\mathrm{CH}_{4}$ and gave values of $42 \%, 41 \%$ and $50 \%$, respectively (Methven et al., 2001). The same analysis was performed for NAMBLEX with values of $41 \%, 63 \%$ and $57 \%$ calculated for the same species. For $\mathrm{CO}$ and $\mathrm{CH}_{4}$ therefore, the fluctuations in concentration are better related to air mass origin than they were during EASE96. This is in part due to a more distinct difference between polluted and unpolluted or clean events during NAMBLEX.

\section{Summary}

In this overview paper, the NAMBLEX field campaign was placed in the context of previous intensive field campaigns in the marine boundary layer (MBL), in particular those held at Mace Head. NAMBLEX represented one of the most detailed studies of the MBL, and chemists, physicists and meteorologists worked closely together to deploy a wide range of instrumentation and models for the measurement and interpretation of trace gases and aerosols. A detailed listing of the deployed instrumentation was given, and species data coverage, together with a summary of the operational details for each instrument. For measurements not considered in detail in other papers in this issue, time-series of measurements were presented and discussed, and interpreted in terms of classifications based on calculated air-mass back trajectories. The conditions encountered during NAMBLEX were compared with the EASE96 campaign, which took place at Mace Head at a similar time of year.

\section{Appendix A}

\section{Papers in the NAMBLEX Special Issue}

Heard, D. E., Read, K. A., Methven, J., et al.: The North Atlantic Marine Boundary Layer Experiment (NAMBLEX). 
Overview of the campaign held at Mace Head, Ireland, in summer 2002.

Norton, E. G., Vaughan, G., Methven, J., Coe, H., Brooks, B., Gallagher, M., and Longley, I.: Boundary layer structure and decoupling from synoptic scale flow during NAMBLEX.

Lewis, A. C., Hopkins, J. R., Carpenter, L. J., Stanton, J., Read, K. A., and Pilling, M. J.: Sources and sinks of acetone, methanol, and acetaldehyde in North Atlantic air.

Purvis, R. M., McQuaid, J. B., Lewis, A. C., Hopkins, J. R., and Simmonds, P.: Horizontal and vertical profiles of ozone, CO, NMHCs, and DMS near the Mace Head Observatory, Ireland.

Carpenter, L. J., Wevill, D. J., O’Doherty, S., Spain, G., and Simmonds, P. G.: Atmospheric bromoform at Mace Head, Ireland: Evidence for a peatland source.

Jackson, A. and Morgan, R. B.: Gas phase hydroperoxide measurements at Mace Head, Ireland, during the NAMBLEX campaign.

Still T. J., Al-Haider, S., Seakins, P. W., Sommariva, R., Stanton, J. C., Mills, G., and Penkett, S.: Ambient formaldehyde measurements made at a remote marine boundary layer site during the NAMBLEX campaign. A comparison of data from chromatographic and modified Hantzsch techniques.

Saiz-Lopez, A., Shillito, J. A., Coe, H., and Plane, J. M. C.: Measurements and modelling of $\mathrm{I}_{2}, \mathrm{IO}, \mathrm{OIO}, \mathrm{BrO}$ and $\mathrm{NO}_{3}$ in the mid-latitude marine boundary layer.

Bitter, M., Ball, S. M., Povey, I. M., and Jones, R. L.: A broadband cavity ringdown spectrometer for in-situ measurement of atmospheric trace gases.

Bitter, M., Ball, S. M., Povey, I. M., Jones, R. L., SaizLopez, A., and Plane, J. M. C.: Measurements of $\mathrm{NO}_{3}$, $\mathrm{N}_{2} \mathrm{O}_{5}, \mathrm{OIO}, \mathrm{I}_{2}$, water vapour and aerosol optical depth by broadband cavity ring down spectroscopy during the NAMBLEX campaign.

Saiz-Lopez, A., Plane, J. M. C., McFiggans, G., Ball, S. M., Bitter, M., Jones, R. L., Hongwei, C., and Hoffmann, T.: Modelling molecular iodine emissions in a coastal marine environment: the link to particle formation.

Smith, S., Lee, J. D., Bloss, W. J., Johnson, G. P., Ingham, T., and Heard, D. E.: Concentrations of $\mathrm{OH}$ and $\mathrm{HO}_{2}$ radicals during NAMBLEX: Measurement and steady state analysis.

Sommariva, R., Bloss, W. J., Carslaw, N., Haggerstone, A.-L., Heard, D. E., Lee, J. D., McFiggans, G., Monks, P. S., Pilling, M. J., Plane, J. M. C., Rickard, A. R., and SaizLopez, A.: $\mathrm{OH}$ and $\mathrm{HO}_{2}$ chemistry during the NAMBLEX campaign.

Fleming, Z., Monks, P. S., Rickard, A. R., Heard, D. E., Still, T. J., Sommariva, R., Pilling, M. J., Green, T., Brough, N., Penkett, S. A., Lewis, A. C., Lee, J. D., Saiz-Lopez, A., and Plane, J. M. C.: Peroxy radical chemistry at Mace Head, Ireland during the summer of 2002.

Sommariva, R., Pilling, M. J., Fleming, Z., Monks, P. S., Bitter, M., Ball, S., Jones, R., Plane, J. M. C., Saiz Lopez, A., Bloss, W. J., Lee, J. D., and Heard, D. E.: Night-time radical chemistry in the marine boundary layer during the NAMBLEX campaign.

Coe, H., Allan, J., Alfarra, M., Bower, K., Flynn, M., McFiggans, G., Topping, D., Williams, P., Dall'Osto, M., Beddows, D., and Harrison, R.: A physical and chemical characterisation of aerosol particles during the North Atlantic Boundary Layer Experiment.

Dall'Osto, M., Harrison, R. M., Furutani, H., Prather, K. A., Coe, H., and Allan, J. D.: Studies of aerosol at a coastal site using two aerosol Mass Spectrometry instruments and identification of biogenic particle types.

Heard, D. E.: A summary of the major results from the NAMBLEX campaign.

Acknowledgements. The success of this campaign was due to the hard work of all the instrument scientists, modellers and principal investigators, and D. E. Heard is grateful to all of them. The Mace Head site is operated by the National University of Ireland, Galway, and the AGAGE instrumentation by the University of Bristol. Thanks are given to all the mechanical and electronics workshops at each of the participating institutes for their hard work in the preparation of instruments for the campaign. We are grateful to the Natural Environment Research Council for funding the work (grant number NER/A/S/2000/01313) and for providing core-support for some of the instruments through the National Centres for Atmospheric Science (NCAS) Universities Facility for Atmospheric Measurements (UFAM). Further details of UFAM can be found at http://www.env.leeds.ac.uk/ufam/.

Edited by: A. Hofzumahaus

\section{References}

Allan, B. J., Carslaw, N., Coe, H., Burgess, R. A., and Plane, J. M. C.: Observations of the Nitrate Radical in the Marine Boundary Layer, J. Atmos. Chem., 33, 129-154, 1999.

Allan, J. D., Jimenez, J. L., Coe, H., Bower, K. N., Williams, P. I., and Worsnop, D. R.: Quantitative sampling using an Aerodyne Aerosol Mass Spectrometer. Part 1: Techniques of data interpretation and error analysis, J. Geophys. Res., 108(D9), 4090, doi:10.1029/2002JD002358, 2003.

Atkinson, R., Baulch, D. L., Cox, R. A., Hampson, R. F. H., Kerr, J. A., Rossi, M. J., and Troe, J.: Evaluated kinetic, photochemical and heterogeneous data for atmospheric chemistry: Supplement V, IUPAC subcommittee on gas kinetic data evaluation for atmospheric chemistry, Journal of Physical Chemistry Reference data, Data 26, 521-1011, 1997.

Bauguitte, S.: A Study of Topospheric Reactive Nitrogen Oxides in the North Atlantic Region, School of Environmental Sciences, University of East Anglia., 448, November 2000.

Bitter, M., Ball, S. M., Povey, I. M., and Jones, R. L.: A broadband cavity ringdown spectrometer for in-situ measurement of atmospheric trace gases, Atmos. Chem. Phys., 2547-2560, 2005.

Bloss, W. J., Lee, J. D., Johnson, G. P., Sommariva, R., Heard, D. E., Saiz-Lopez, A., Plane, J. M. C., McFiggans, G., Coe, H., Flynn, M., Williams, P., Rickard, A. R., and Fleming, Z. L.: Impact of halogen monoxide chemistry upon boundary layer $\mathrm{OH}$ and 
$\mathrm{HO}_{2}$ concentrations at a coastal site, Geophys. Res. Lett., 32(6), L06814, doi:10.1029/2004GL022084, 2005.

Brasseur, G., Orlando, J. J., and Tyndall, G.: Atmospheric chemistry and global change, OUP, Oxford, 1999.

Brasseur, G. P., Prinn, R. G., and Pszenny, A. A. P.: The Changing Atmosphere. An integration and Synthesis of a Decade of Tropospheric Chemistry Research, in: Global Change - The IGBP Series, Springer, Heidelberg, 2002.

Brough, N., C. E. Reeves, Penkett, S. A., Stewart, D. J., Dewey, K., Kent, J., Barjat, H., Monks, P. S., Ziereis, H., Stock, P., Huntrieser, H., and Schlager, H.: Intercomparison of aircraft measurements on board the C-130 and Falcon over southern Germany during EXPORT 2000, Atmos. Chem. Phys., 3, 21272138, 2003, http://www.atmos-chem-phys.net/3/2127/2003/.

Cape, J. N., Methven, J., and Hudson, L. E.: The use of trajectory cluster analysis to interpret trace gas measurements at Mace Head, Ireland, Atmos. Environ., 34, 3651-3663, 2000a.

Carpenter, L. J., Lewis, A. C., Hopkins, J. R., Read, K. A., Longley, I. D., and Gallagher, M. W.: Uptake of methanol to the North Atlantic Ocean surface, in: Global Biogeochemical Cycles, GB4027, 2004.

Carpenter, L. J., Liss, P. S., and Penkett, S. A.: Marine organohalogens in the atmosphere over the Atlantic and Southern Oceans, J. Geophys. Res., 108(D9), 4256, doi:10.1029/2002JD002769, 2003.

Carpenter, L. J., Monks, P. S., Bandy, B. J., Penkett, S. A., Galbally, I. E., and Meyer, C. P.: A study of peroxy radicals and ozone photochemistry at coastal sites in the northern and southern hemispheres, J. Geophys. Res., 102(D21), 25 417-25 427, 1997.

Carpenter, L. J., Sturges, W. T., Penkett, S. A., Liss, P. S., Alicke, B., Hebestreit, K., and Platt, U.: Short-lived alkyl iodides and bromides at Mace Head, Ireland: Links to biogenic sources and halogen oxide production, J. Geophys. Res., 104(D1), 16791689, 1999.

Carpenter, L. J., Wevill, D. J., ODoherty, S., Spain, G., and Simmonds, P. G.: Atmospheric bromoform at Mace Head, Ireland: Evidence for a peatland source, Atmos. Chem. Phys., 29272934, 2005.

Carslaw, N., Bell, N., Lewis, A. C., McQuaid, J. B., and Pilling, M. J.: A detailed case study of isoprene chemistry during the EASE96 Mace Head campaign., Atmos. Environ., 34, 28272836, 2000.

Carslaw, N., Creasey, D. J., Heard, D. E., Jacobs, P. J., Lee, J. D., Lewis, A. C., McQuaid, J. B., Pilling, M. J., Bauguitte, S., Penkett, S. A., Monks, P. S., and Salisbury, G.: Eastern Atlantic Spring Experiment 1997 (EASE97) - 2. Comparisons of model concentrations of $\mathrm{OH}, \mathrm{HO}_{2}$, and $\mathrm{RO}_{2}$ with measurements, J. Geophys. Res.-Atmos., 107(D14), 4190, 2002.

Carslaw, N., Creasey, D. J., Heard, D. E., Lewis, A .C., McQuaid, J. B., Pilling, M. J., Monks, P. S., Bandy, B. J., and Penkett, S. A.: Modeling $\mathrm{OH}, \mathrm{HO}_{2}$, and $\mathrm{RO}_{2}$ radicals in the marine boundary layer -1 . Model construction and comparison with field measurements, J. Geophys. Res., 104(D23), 30 241-30 255, 1999a.

Carslaw, N., Creasey, D. J., Heard, D. E., Lewis, A. C., McQuaid, J. B., Pilling, M. J., Monks, P. S., Bandy, B. J., and Penkett, S. A.: Modelling $\mathrm{OH}, \mathrm{HO}_{2}$, and $\mathrm{RO}_{2}$ radicals in the marine boundary layer. 1. Model construction and comparison with field measurements, J. Geophys. Res., 104(D23), 30 241-30 255, 1999b.

Coe, H., Allan, J. D., Alfarra, M. R., Bower, K. N., Flynn, M. J.,
McFiggans, G. B., Topping, D. O., Williams, P. I., O’Dowd, C. D., Dall'Osto, M., Beddows, D. C. S., and Harrison, R. M.: Chemical and physical characterisation of aerosol particles at a remote coastal location, Mace Head, Ireland, during NAMBLEX, Atmos. Chem. Phys. Discuss., 5, 11 643-11 678, 2005.

Creasey, D. J., Evans, G. E., Heard, D. E., and Lee, J. D.: Measurements of $\mathrm{OH}$ and $\mathrm{HO}_{2}$ concentrations in the Southern Ocean marine boundary layer, J. Geophys. Res., 108(D15), 4475, doi:10.1029/2002JD003206, 2003.

Creasey, D. J., Heard, D. E., and Lee, J. D.: Eastern Atlantic Spring Experiment 1997 (EASE97) 1. Measurements of OH and $\mathrm{HO}_{2}$ concentrations at Mace Head, Ireland, J. Geophys. Res., 107(D10), doi:10.1029/2001JD000892, 4091, 2002.

Dall'Osto, M., Beddows, D. C. S., Kinnersley, R. P., Harrison, R. M., Donovan, R. J., and Heal, M. R.: Characterization of individual airborne particles by using aerosol time-of-flight mass spectrometry at Mace Head, Ireland, J. Geophys. Res., 109(D21), D21302, doi:10.1029/2004JD004747, 2004.

Dall'Osto, M., Harrison, R. M., Furutani, H., Prather, K. A., Coe, H., Allan, J. D.: Studies of aerosol at a coastal site using two aerosol Mass Spectrometry instruments and identification of biogenic particle type, Atmos. Chem. Phys. Discuss., 5, 10799 $10838,2005$.

De Leeuw, G., Moerman, M., Cohen, L., Brooks, B., Smith, M., and Vignati, E.: Aerosols, bubbles and sea spray production studies during the RED experiments, Proceedings of the Annual Meeting of the American Meteorological Society, 9.6, Long Beach CA, February 2003.

Derwent, R. G. and Davies, T. J.: Modelling the impact of $\mathrm{NO}_{\mathrm{x}}$ on hydrocarbon control on photochemical ozone in Europe, Atmos. Environ., 28(12), 2039-2052, 1994.

Derwent, R. G., Simmonds, P. G., and Collins, W. J.: Ozone and Carbon-Monoxide Measurements at a Remote Maritime Location, Mace-Head, Ireland, from 1990 to 1992, Atmos. Environ., 2623-2637, 1994.

Derwent, R. G., Simmonds, P. G., Seuring, S., and Dimmer, C.: Observation and interpretation of the seasonal cycles in the surface concentrations of ozone and carbon monoxide at Mace Head, Ireland from 1990 to 1994, Atmos. Environ., 32(2), 145-157, 1998.

ECMWF: The description of the ECMWF/WRCP Level III-A global atmospheric data archive, ECMWF, Shinfield Park, Reading, RG2 9AX, UK, 1995.

Evans, M. J., Shallcross, D. E., Law, K. S., Wild, J. O. F., Simmonds, P. G., Spain, T. G., Berrisford, P., Methven, J., Lewis, A. C., McQuaid, J. B., Pilling, M. J., Bandy, B. J., Penkett, S. A., and Pyle, J. A.: Evaluation of a Lagrangian box model using field measurements from EASE (Eastern Atlantic Summer Experiment) 1996, Atmos. Environ., 3843-3863, 2000.

Fleming, Z., Monks, P. S., Rickard, A. R., Heard, D. E., Still, T. J., Sommariva, R., Pilling, M. J., Green, T., Brough, N., Penkett, S. A., Lewis, A. C., Lee, J. D., Saiz-Lopez, A., and Plane, J. M. C.: Peroxy radical chemistry at Mace Head, Ireland during the summer of 2002, Atmos. Chem. Phys. Discuss., 5, 12313 $12371,2005$.

Geever, M., ODowd, C., van Ekeren, S., Flanagan, R., Nilsson, D., de Leeuw, G. and Rannik, U.: Sub-micron sea-spray fluxes, Geophys. Res. Lett., 32, L15810, doi:10.1029/2005GL023081, 2005.

Grenfell, J. L., Harrison, R. M., Allen, A. G., Shi, J. P., Penkett, S. A., O’Dowd, C. D., Smith, M. H., Hill, M. K., Robertson, L., 
Hewitt, C. N., Davison, B., Lewis, A. C., Creasey, D. J., Heard, D. E., Hebestreit, K., Alicke, B., and James, J.: An analysis of rapid increases in condensation nuclei concentrations at a remote coastal site in western Ireland, J. Geophys. Res., 104(D11), 13 771-13 780, 1999.

Haggerstone, A. L., Carpenter, L. J., Carslaw, N., and McFiggans, G.: Improved model predictions of $\mathrm{HO}_{2}$ with gas to partical mass transfer rates calculated using aerosol number size distibutions, J. Geophys. Res., 110, D04303, doi:10.1029/2004JD005282, 2005.

Hamilton, J. F. and Lewis, A. C.: Monoaromatic complexity in urban air and gasoline assessed using comprehensive GC and fast GC-TOF/MS, Atmos. Environ., 37(5), 589-602, 2003.

Hard, T. M., O'Brien, R. J., Chan, C. Y., Mehrabzadeh, A. A.:Tropospheric free radical determination by FAGE, Environ. Sci. and Technology., 18(10), 768-777, 1984.

Heard, D. E. and Pilling, M. J.: Measurement of $\mathrm{OH}$ and $\mathrm{HO}_{2}$ in the troposphere, Chemical Reviews, 103, 5163-5198, 2003.

Hofzumahaus, A., Lefer, B. L., Monks, P. S., Hall, S. R., Kylling, A., Mayer, B., Shetter, R. E., Junkermann, W., Bais, A., Calvert, J. G., Cantrell, C. A., Madronich, S., Edwards, G. D., Kraus, A., Muller, M., Bohn, B., Schmitt, R., Johnston, P., McKenzie, R., Frost, G. J., Griffioen, E., Krol, M., Martin, T., Pfister, G., Roth, E. P., Ruggaber, A., Swartz, W. H., Lloyd, S. A., and Weele, M. V.: Photolysis frequency of $\mathrm{O}_{3}$ to $\mathrm{O}^{1} \mathrm{D}$ : Measurements and modelling during the International Photolysis Frequency Measurement and Modelling Intercomparison (IPMMI), J. Geophys. Res., 109, D08S90, doi:1029/2003JD004333, 2004.

Holton, J. R., Pyle, J. A., and Curry, J. A. (Eds.): Encyclopaedia of Atmospheric Sciences, Elsevier, 2003.

Hopkins, J. R., Lewis, A. C., and Read, K. A.: A Two-column method for long-term monitoring of Non-methane hydrocarbons (NMHC) and oxygenated volatile organic compounds (o-VOCs), J. Environ. Monitor., 5, 8-13, 2002.

Jenkin, M. E., Saunders, S. M., and Pilling, M. J.: The tropospheric degradation of volatile organic compounds: A protocol for mechanism development, Atmos. Environ., 31, 81-104, 1997.

Jenkin, M. E., Saunders, S. M., Wagner, V., and Pilling, M. J.: Protocol for the development of the Master Chemical Mechanism, MCM v3 (Part B): tropospheric degradation of aromatic volatile organic compounds, Atmos. Chem. Phys., 3, 181-193, 2003, http://www.atmos-chem-phys.net/3/181/2003/.

Jennings, S. G., Kleefeld, C., O’Dowd, C. D., Junker, C., Spain, T. G., O’Brien, P., Roddy, A. F., and O'Connor, T. C.: Mace Head Atmospheric Research Station-characterization of aerosol radiative parameters, Boreal Environ. Res., 303-314, ISSN 12396095, 2003.

Jobson, T., Parrish, D. D., Goldan, P., Kuster, W., Fehsenfeld, F. C., Blake, D. R., Blake, N. J., and Niki, H.: Spatial and temporal variability of non-methane hydrocarbon mixing ratios and their relation to photochemical lifetime, J. Geophys. Res., 103(D11), $13557-13567,1998$.

Lewis, A. C., Bartle, K. D., Heard, D. E., McQuaid, J. B., Pilling, M. J., and Seakins, P. W.: In situ, gas chromatographic measurements of non-methane hydrocarbons and dimethyl sulfide at a remote coastal location (Mace Head, Eire) July-August 1996, J. Chem. Soc., Faraday Transactions, 93(16), 2921-2927, 1997.

Lewis, A. C., Carpenter, L. J., and Pilling, M. J.: Non-methane hydrocarbons in Southern Ocean boundary layer air, J. Geophys. Res., 106(D5), 4987-4994, 2001.
Lewis, A. C., McQuaid, J. B., Carslaw, N., and Pilling, M. J.: Short communication: Diurnal cycles of short-lived tropospheric alkenes at a North Atlantic coastal site, Atmos. Environ., 33, 2417-2422, 1999.

Lewis, A. C., Hopkins, J. R., Carpenter, L. J., Stanton, J., Read, K. A., and Pilling, M. J.: Sources and sinks of acetone, methanol, and acetaldehyde in North Atlantic marine air, Atmos. Chem. Phys., 5, 1963-1974, 2005, http://www.atmos-chemphys.net/5/1963/2005/.

McFiggans, G., Coe, H., Burgess, R., Allan, J., Cubison, M., Alfarra, M. R., Saunders, R., Saiz-Lopez, A., Plane, J. M. C., Wevill, D. J., Carpenter, L. J., Rickard, A. R., and Monks, P. S.: Direct evidence for coastal iodine particles from Laminaria macroalgae - linkage to emissions of molecular iodine, Atmos. Chem. Phys., 4, 701-713, 2004, http://www.atmos-chemphys.net/4/701/2004/.

Methven, J., Evans, M., Simmonds, P., and Spain, G.: Estimating relationships between air mass origin and chemical composition, J. Geophys. Res., 106(D5), 5005-5019, 2001.

Monks, P. S.: A review of the observations and origins of the spring ozone maximum, Atmos. Environ., 34(21), 3545-3561, 2000.

Monks, P. S.: Gas-phase radical chemistry in the troposphere, Chem. Soc. Rev., 34(5), 376-395, 2005.

Monks, P. S., Carpenter, L. J., Penkett, S. A., and Ayers, G. P.: Night-time peroxy radical chemistry in the remote marine boundary layer over the Southern ocean, Geophys. Res. Lett., 23(5), 535-538, 1996.

Monks, P. S., Carpenter, L. J., Penkett, S. A., Ayers, G. P., Gillet, R. W., Galbally, I. E., and Meyer, C. P.: Fundamental ozone photochemistry in the remote marine boundary layer: The SOAPEX experiment, measurement and theory, Atmos. Environ., 32(21), 3647-3664, 1998.

Monks, P. S., Rickard, A. R., Hall, S. L., and Richards, N. A. D.: Attenuation of spectral actinic flux and photolysis frequencies at the surface through homogenous cloud fields, J. Geophys. Res.Atmospheres, 109(D17), D17206, doi:10.1029/2003JD004076, 2004.

Monks, P. S., Salisbury, G., Holland, G., Penkett, S. A., and Ayers, G. P.: A seasonal comparison of ozone photochemistry in the remote marine boundary layer, Atmos. Environ., 34(16), 25472561, 2000.

Morgan, R. B. and Jackson, A. V.: Measurements of gas-phase hydrogen peroxide and methyl hydroperoxide in the coastal environment during the PARFORCE project, J. Geophys. Res.Atmospheres, 107(D19), 8109, doi:10.1029/2000JD000257, 2002.

Nilsson, E. D., Rannik, U., Swietlicki, E., Leck, C., Aalto, P. P., Zhou, J., and Norman, M.: Turbulent Aerosol Fluxes Over the Arctic Ocean: 2. Wind driver sources from the sea, J. Geophys. Res., 106(D23), 32 139-32 154, 2001.

Norton, E. G., Vaughan, G., Methven, J., Coe, H., Brooks, B., Gallagher, M., and Longley, I.: Boundary layer structure and decoupling from synoptic scale flow during NAMBLEX, Atmos. Chem. Phys., 6, 433-445, 2006, http://www.atmos-chemphys.net/6/433/2006/.

Novelli, P. C., Lang, P. M., Masarie, K. A., Hurst, D. F., Myers, R., and Elkins, J. W.: Molecular hydrogen in the troposphere: Global distribution and budget, J. Geophys. Res., 30 427-30 444, 1999. 
O’Dowd, C. D., Facchini, M. C., Cavalli, F., Ceburnis, D., Mircea, M., Decesari, S., Fuzzi, S., Yoon, Y. J., and Putaud, J. P.: Biogenically driven organic contribution to marine aerosol, Nature, 431(7009), 676-680, 2004.

O’Dowd, C. D., Hameri, K., Makela, J., Vakeva, M., Aalto, P., de Leeuw, G., Kunz, G. J., Becker, E., Hansson, H. C., Allen, A. G., Harrison, R. M., Berresheim, H., Geever, M., Jennings, S. G., and Kulmala, M.: Coastal new particle formation: Environmental conditions and aerosol physicochemical characteristics during nucleation bursts, J. Geophys. Res., 107(D19), 8107, doi:10.1029/2000JD000206, 2002a.

O’Dowd, C. D., Hameri, K., Makela, J. M., Pirjola, L., Kulmala, M., Jennings, S. G., Berresheim, H., Hansson, H. C., de Leeuw, G., Kunz, G. J., Allen, A. G., Hewitt, C. N., Jackson, A., Viisanen, Y., and Hoffmann, T.: A dedicated study of New Particle Formation and Fate in the Coastal Environment (PARFORCE): Overview of objectives and achievements, J. Geophys. Res., 107(D19), 8108, doi:10.1029/2001JD000555, 2002b.

O’Dowd, C., McFiggans, G., Creasey, D. J., Pirjola, L., Hoell, C., Smith, M. H., Allan, B. J., Plane, J. M. C., Heard, D. E., Lee, J. D., Pilling, M. J., and Kulmala, M.: On the photochemical production of new particles in the coastal boundary layer, Geophys. Res. Lett., 26(12), 1707-1710, 1999.

Purvis, R. M., McQuaid, J. B., Lewis, A. C., Hopkins, J. R., Simmonds, P.: Horizontal and vertical profiles of ozone, CO, NMHCs, and DMS near the Mace Head Observatory, Ireland, Atmos. Chem. Phys. Discuss., 5, 12 505-12 530, 2005.

Rickard, A. R., Salisbury, G., Monks, P. S., Lewis, A. C., Bauguitte, S. A., Bandy, B. J., Clemitshaw, K. C., and Penkett, S. A.: Comparison of measured ozone production efficiencies in the marine boundary layer at two european coastal sites under different pollution regimes, J. Atmos. Chem., 43, 107-134, 2002.

Saiz-Lopez, A. and Plane, J. M. C.: Novel iodine chemistry in the marine boundary layer, Geophys. Res. Lett., 31(4), L04112, doi:10.1029/2003GL019215, 2004.

Saiz-Lopez, A., Plane, J. M. C., and Shillito, J. A.: Bromine oxide in the mid-latitude marine boundary layer, Geophys. Res. Lett., 31(3), L03111, doi:10.1029/2003GL018956, 2004.

Saiz-Lopez, A., Plane, J. M. C., McFiggans, G., Ball, S. M., Bitter, M., Jones, R. L., Hongwei, C., and Hoffmann, T.: Modelling molecular iodine emissions in a coastal marine environment: the link to new particle formation, Atmos. Chem. Phys., 883-895, 2006a.

Saiz-Lopez, A., Shillito, J. A., Coe, H., and Plane, J. M. C.: Measurements and modelling of $\mathrm{I}_{2}, \mathrm{IO}, \mathrm{OIO}, \mathrm{BrO}$ and $\mathrm{NO}_{3}$ in the mid-latitude marine boundary layer, Atmos. Chem. Phys., 6, 1513-1528, 2006b.

Salisbury, G., Monks, P. S., Bauguitte, S., Bandy, B. J., and Penkett, S. A.: A seasonal comparison of the ozone photochemistry in clean and polluted air masses at Mace Head, Ireland, J. Atmos. Chem., 41(2), 163-187, 2002.

Salisbury, G., Rickard, A. R., Monks, P. S., Allan, B. J., Bauguitte, S., Penkett, S. A., Carslaw, N., Lewis, A. C., Creasey, D. J., Heard, D. E., Jacobs, P. J., and Lee, J. D.: Production of peroxy radicals at night via reactions of ozone and the nitrate radical in the marine boundary layer, J. Geophys. Res., 106(D12), 12669 $12687,2001$.
Saunders, S. M., Jenkin, M. E., Derwent, R. G., and Pilling, M. J.: Protocol for the development of the Master Chemical Mechanism, MCM v3 (Part A): tropospheric degradation of nonaromatic volatile organic compounds, Atmos. Chem. Phys., 3, 161-180, 2003, http://www.atmos-chem-phys.net/3/161/2003/.

Savage, N. H., Harrison, R. M., Monks, P. S., and Salisbury, G.: Steady-state modelling of hydroxyl radical concentrations at Mace Head during the EASE 97 campaign, May 1997, Atmos. Environ., 35, 515-524, 2001.

Schwartz, S. E. and Freiberg, J. E.: Mass-transport considerations pertinent to aqueous reactions of gases in liquid-water clouds, in: Chemistry of multiphase atmospheric systems, Springer, Heidelberg, 1984.

Simmonds, P. G., Seuring, S., Nickless, G., and Derwent, R. G.: Segregation and interpretation of ozone and carbon monoxide measurements by air mass origin at the TOR station Mace Head, Ireland from 1987 to 1995, J. Atmos. Chem., 28, 45-59, 1997.

Simmonds, P. G., Derwent, R. G., O’Doherty, S., Ryall, D. B., Steele, L. P., Langenfelds, R. L., Salameh, P., Wang, H. J, Dimmer, C. H., Hudson, L. E.: Continuous high-frequency observations of hydrogen at the Mace Head baseline atmospheric monitoring station over the 1994-1998 period, J. Geophys. Res., 105(D10), 12 105-12 121, 2000.

Simmonds, P. G., Derwent, R. G., Manning, A. L., Spain, G.:Significant growth in surface ozone at Mace Head, Ireland, 1987-2003, Atmos. Environ., 38, 4769-4778, 2004.

Smith, S., Lee, J. D., Bloss, W. J., Johnson, G. P., Ingham, T., and Heard, D. E.: Concentrations of $\mathrm{OH}$ and $\mathrm{HO}_{2}$ radicals during NAMBLEX: measurements and steady state analysis, Atmos. Chem. Phys., 6, 1435-1453, 2006, http://www.atmos-chemphys.net/6/1435/2006/.

Sommariva, R., Haggerstone, A. L., Carpenter, L. J., Creasey, D. J., Carslaw, N., Heard, D. E., Lee, J. D., Lewis, A. C., Pilling, M. J., and Zador, J.: $\mathrm{OH}$ and $\mathrm{HO}_{2}$ chemistry in clean marine air during SOAPEX-2, Atmos. Chem. Phys., 4, 839-856, 2004, http://www.atmos-chem-phys.net/4/839/2004/.

Sommariva, R., Bloss, W. J., Carslaw, N., Haggerstone, A.-L., Heard, D. E., Lee, J. D., McFiggans, G., Monks, P. S., Pilling, M. J., Plane, J. M. C., Rickard, A. R., and Saiz-Lopez, A.: OH and $\mathrm{HO}_{2}$ chemistry during NAMBLEX: roles of oxygenates, halogen oxides and heterogeneous uptake, Atmos. Chem. Phys. Discuss., 5, 10947-10 996, 2005a.

Sommariva, R., Ball, S. M., Bitter, M., Bloss, W. J., Fleming, Z. L., Heard, D. E., Jones, R. L., Lee, J. D., Monks, P. S., Pilling, M. J., Plane, J. M. C., and Saiz Lopez, A.: Night-time radical chemistry during the NAMBLEX campaign, Atmos. Chem. Phys. Discuss., accepted, 2006b.

Still, T. J., Al-Haider, S., Seakins, P. W., Sommariva, R., Stanton, J. C., Mills, G., and Penkett, S.: Ambient formaldehyde measurements made at a remote marine boundary layer site during the NAMBLEX campaign a comparison of data from chromatographic and modified Hantzsch techniques, Atmos. Chem. Phys. Discuss., 5, 12 531-12 567, 2005.

Wevill, D. J. and Carpenter, L. J.: Automated measurement and calibration of reactive volatile halogenated organic compounds in the atmosphere, Analyst, 129(7), 634-638, 2004. 